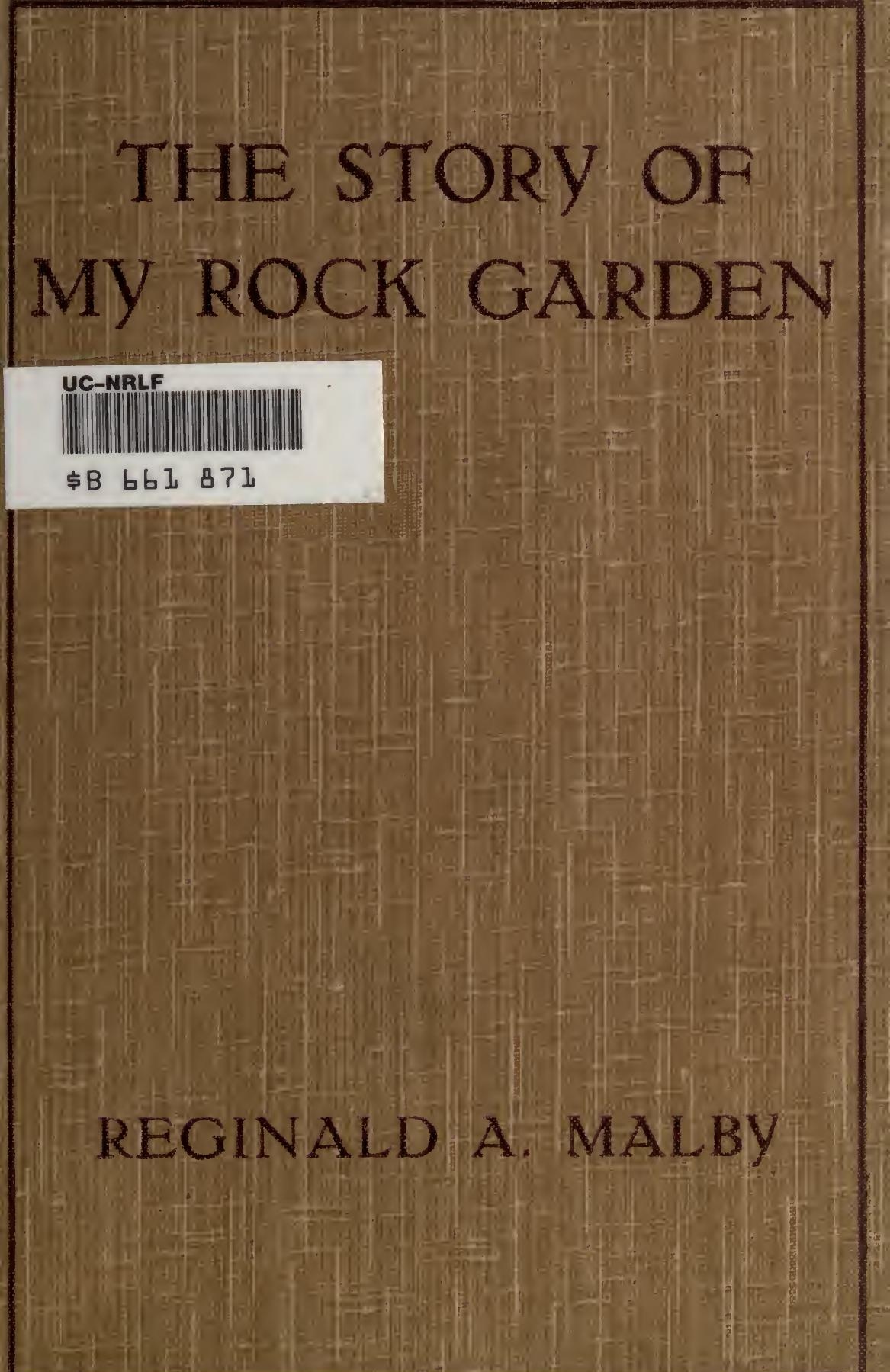




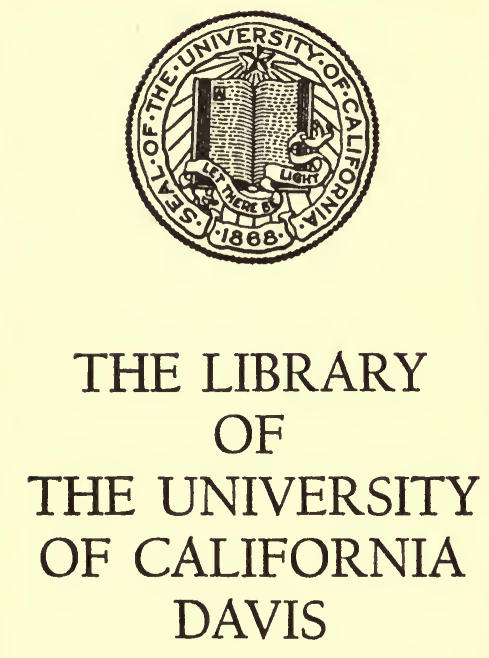

GIFT OF

MISS HELEN R. BIJASDALE 


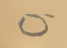

$71=7,40,5=2.5$ 
Digitized by the Internet Archive in 2007 with funding from Microsoft Corporation 
THE STORY OF MY ROCK GARDEN 
First Edition, May, 1912.

Revised Edition, Oclober, 1912.

Third Edition, April, 1913.

Fourth Edizion, May, 1919. 



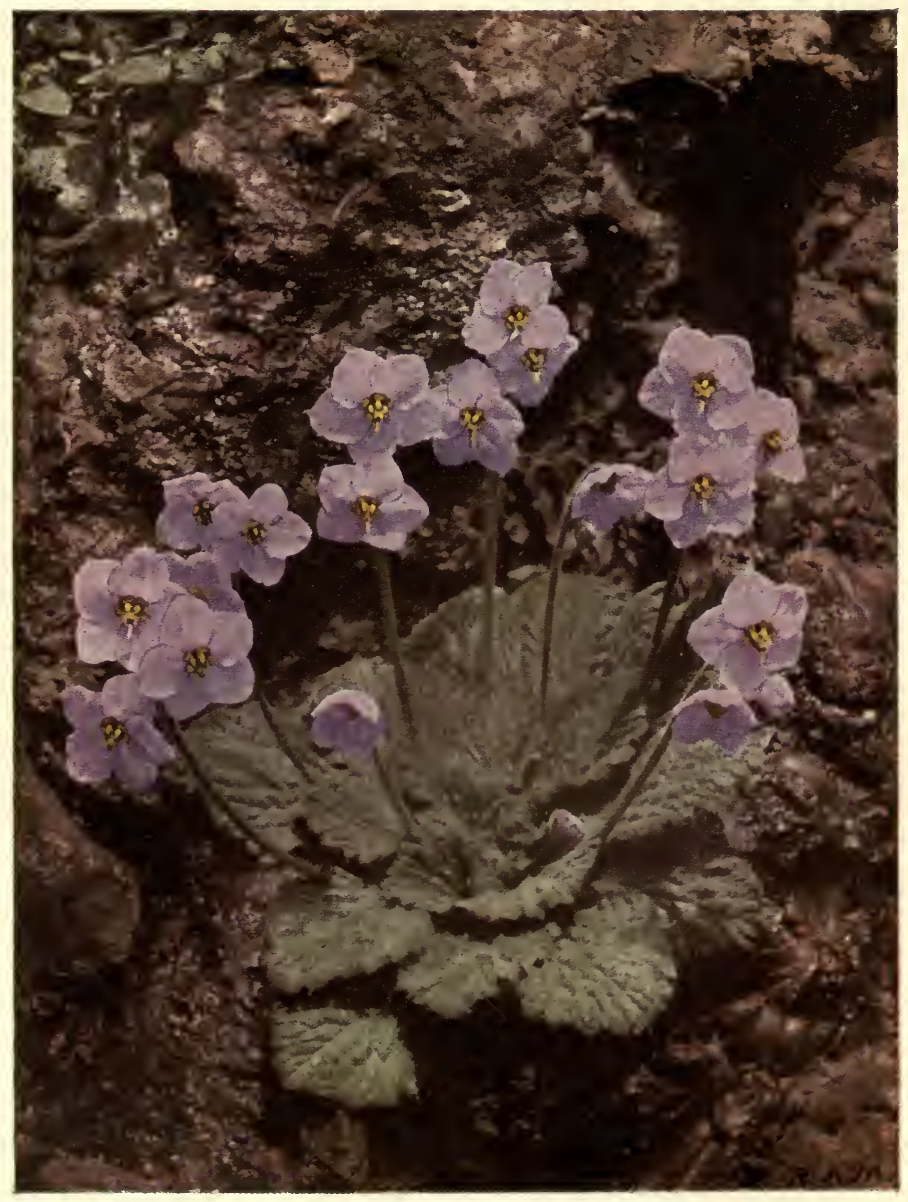

RAMONDIA PYRENAICA. 


\title{
THE STORY OF
}

\section{MY ROCK GARDEN}

BY

REGINALD A. MALBY, F.R.P.s., F.R.H.s.

WITH INTRODUCTION BY

W. IRVING, OF KEW GARDENS

ILLUSTRATED WITH PHOTOGRAPHIC REPRODUCTIONS

AND COLOUR PLATES BY THE AUTHOR

\author{
Fourth Edition
}

LONDON

HEADLEY BROS. PUBLISHERS, LTD.

72, OXFORD STREET, W.r.

\section{LIBRARY}

UNIVERSITY OF CALIFORNIA 
DEDICATED

TO

MY FATHER

TO WHOSE CAREFUL TRAINING AND APPRECIATION OF THOROUGHNESS

ANY SUCCESS I MAY HAVE ATTAINED IS DUE 


\section{CONTENTS}

CHAPTER

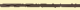

INTRODUCTION

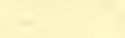

PAGE

\section{1. - MY GARDEN AN}

D IT

TS EN

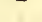

$\sqrt{10}$

\section{II. - PLANNING AND BUILDING}

III.-THE MORAINE

IV.-PLANTING THE GARDEN -

V.-PROPAGATING

VI.-SPECIAL METHODS OF PLANTING AND

THE USE OF DWARF TREES - - 76

VII.-A DESCRIPTION OF MY GARDEN AND ITS

INHABITANTS THE YEAR THROUGH 9 I VIII. -

\begin{tabular}{|c|c|c|c|c|c|}
\hline APPENDIX. - & IST & OF & & NTS & \\
\hline SPECIAL & POSI & TIONS & & - & I20 \\
\hline INDEX - & - & - & & - & I30 \\
\hline
\end{tabular}





\section{ILLUSTRATIONS}

COLOUR PLATES

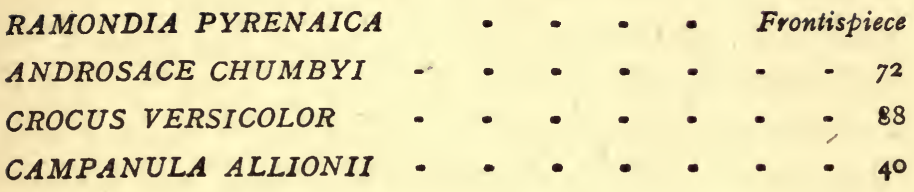

SAXIFRAGA HOSTII AND SEDUM TURKESTANICUM UNDER HOAR-FROST - $\quad$ - $\quad$ - $\quad$ - $\quad$ - $\quad$ I6 THE EDGE OF THE PATH - $\quad \cdot \quad \cdot \quad \cdot \quad \cdot \quad 17$ EDRAIANTHUS SERPYLLIFOLIUS - - - • - I7 SEMPERVIVUM ARACHNOIDEUM, v. LAGGERI - - 24 GLASS PROTECTION AGAINST WIND AND RAIN - $\quad 24$ THE POOL IN WINTER - - - - - - - 25 TROLLIUS IN THE BOG GARDEN - - - - $\quad 25$ PRIMULA FARINOSA - - - - - - - 32 PRIMULA DENTICULATA, SHOWING RAPID GROWTH 33 DRABA DEDEANA ON THE MORAINE - - - - 36 THE MORAINE - - - - - - - - - 37 SILENE ACAULIS ON THE MORAINE - • - 44 


\section{ILLUSTRATIONS}

ERITRICHIUM NANUM ON THE MORAINE - - $\quad 45$ DIANTHUS NEGLECTUS - - - - - - • - 48 ARMERIA PLANTAGINEA WITH TAP ROOT EXPOSED- 49 AURICULA, SHOWING NATURE OF ROOTS - - 49 ARTEMISIA VALLESIACA - - - - - - 56 CAMPANULA GARGANICA - - - • - - 57 ARENARIA MONTANA - • - • • - - 64 SAXIFRAGA GRIESEBACHII - - - - - - 65 SAXIFRAGA BURSERIANA - - - - - . 68 SAXIFRAGA CESPITOSA, SHOWING GROWTH - - 69 JUNIPERUS CHINENSIS BEFORE AND AFTER TREAT-

MENT

A CORNER OF MY ROCK GARDEN IN JUNE - $\quad 77$ NARCISSUS BULBOCODIUM, VAR. MONOPHYLLUS - 96 CYCLAMEN NEAPOLITANUM, VAR. ALBUM - - 97 COLCHICUM SPECIOSUM - - - - • • • II2 HOAR-FROST AND MIST IN THE GARDEN • $•$ - I13 


\section{INTRODUCTION}

DURING the last quarter of a century Alpine Gardens have increased in number to a great extent, and the cultivation of Alpine and herbaceous plants has received much more attention than before. This is probably due to the many attractive features in connection therewith, both in the style of gardening and in the plants themselves.

In this little book on the construction and the inhabitants of his Alpine garden the author gives a vivid idea of the use to which even a small garden may be put. He shows how in the space of a few square yards it is possible and easy to build, with any available stone, or other material, an attractive rockery, and on this to grow a large number of interesting and beautiful plants. In the chapter on construction there is a mass of useful information that would be very helpful to anyone who contemplates laying out his garden in this manner.

The number of Alpine or dwarf plants suitable for a rockery is very extensive ; they occupy little space and 
usually their flowers are large in proportion to the plants which produce them. Even if the garden were limited to one family alone, like the Saxifrages, or Rockfoils, these would be ample material to make it most interesting as well as attractive. Of the Rockfoils alone these are well over two hundred kinds in cultivation, many of great beauty when in flower, while in others the chief attraction lies in their rosettes of silver-edged leaves.

With reference to the furnishing of such a garden the author, in describing the occupants of his rock garden, sets himself out to denote those which are easily grown and suitable for different positions. At the same time great attention is given to ensure a succession of flowers over as long a period as possible; a selection of evergreen subjects that will give the rockery a furnished appearance even in the dead season of the year is also emphasized.

The illustrations are a noticeable feature-for here we have evidence of a skilled hand who knows how to show off the best points of a plant or flower to advantage. For while the author admits that his close acquaintance with these plants is of comparatively recent date, the art of photography with him has been a life-long study. Many of the illustrations represent choice and rare plants growing in situ in his garden. 
In conclusion I may suggest that " miffy" plants, although many are beautiful when well grown, are not indispensable to a rock garden. At the same time a great deal of pleasure, as well as disappointment, may be obtained in endeavouring to manage such things as Eritrichium nanum, and where one is successful with these difficult plants, it is with pardonable pride that he wishes to exhibit his treasures. But on the whole there are plenty of tractable, easily-managed plants without worrying about these inhabitants from the higher altitudes, which object to our lower elevation and murky atmosphere.

W. IRving.

Kew. 



\section{CHAPTER I}

\section{MY GARDEN AND ITS ENVIRONMENT}

ALPINE plants have always had a fascination for me, but it was not until some six or seven years ago that I had the opportunity of indulging myself with the delightful pastime of cultivating them at home. About this time I acquired a villa in the suburb of Woodford in Essex-within eight miles of the Bank of England, and attached thereto was a garden of the ordinary size and shape, the chief advantage it possessed from an Alpine-plant grower's point of view being the absence of any large trees. As the ground had received but little attention for some years, and needed a good deal of "getting into shape." no matter for what form of horticulture, it seemed to me an ideal opportunity to create little by little an Alpine garden such as I had long desired to possess.

There were, of course, many factors which act disadvantageously to the Alpine plants-such for instance as the close proximity to the great vapour zone of London, which, over a large part of the year is sending 


\section{I4 THE STORY OF MY ROCK GARDEN}

its leaden coloured pall of smoke gently drifting over from the City, thereby not only cutting out a large amount of the vigour from the light rays, but is ever depositing its injurious particles of by-products upon the foliage. This in time is liable to choke the little mountain plants unaccustomed to anything but the purest of pure air. Then again, the garden as a whole is upon a clay subsoil, with three or four feet of heavy sticky loam on the top.

The last and by no means least of the difficulties I had to face, was the fact that there is no stone quarried anywhere in the neighbourhood and as far as I know, for a very considerable distance.

You will agree that at the outset my chances of success were small indeed, and I was many times told by experienced friends that I should do no good with many of the more difficult plants.

Business connections prevented me removing to a more suitable locality, so I had either to make the best of my disadvantages, or give up the idea altogether. After careful consideration, I chose the former, as I believed that by some thought and ingenuity a large amount of the trouble could be circumvented, and since the space available was small, I felt sure that no other form of gardening would give me the same prolonged period of interest and pleasure as the cultivation of Alpine plants. 
There are hosts of these plants which are of such diminutive stature, that a large number can be accommodated in a tiny space, while if the surroundings are carefully planned and unremitting care given to keeping the whole thing to scale, one can almost believe that the space so planted is three or four times as large as it really is.

Another strong point in favour of this form of gardening is the evergreen character of a large number of the plants-thus giving us the appearance of verdure through our long and usually miserable winters.

How different a well clothed rock garden looks, say in January, when compared with the too often seen desolation of the average villa garden-with its dank and sodden border, from which rise the ghastly stumps of last year's plants. Before these herbaceous subjects have even pretended to hide the barrenness of the surrounding soil, upon the return of spring, the Alpine gardener has had a glorious succession of blossom for at least two months.

From my own small store of experience I knew that from the large number of Alpine plants available, I could, with careful selection, so plant my little garden as to produce a succession of flower practically from January Ist to December 3Ist.

I would here like to say what a large amount of help I received from other, and much more experienced, 


\section{I6 THE STORY OF MY ROCK GARDEN}

Alpine plant growers. It is delightful to find that one of the outstanding features of plant lovers is their readiness to impart information which years of careful study of the plants has given them.

I have always found that if I am in any little difficulty owing to lack of experience, I have only to go to some brother plantsman, and he is only too pleased to place his best advice at my disposal. My thanks are especially due, in this respect, to Mr. E. A. Bowles, M.A., F.L.S., of Waltham Cross, and also to those in charge of the fine collection of Alpine plants at Kew, who have always been most kind to me. I trust I have maintained this kindly spirit of helpfulness, by passing on what knowledge I may possess to other, and still more youthful Alpine plant lovers.

The difficulty of obtaining real stone led me to cast round for an efficient substitute, and I must say that, after considerable experience I find that roughly broken blocks of cement concrete-such as are sometimes obtainable when the foundations of the London roads are being removed-are really very useful. In appearance it is suggestive of conglomerate-its light colour when dry being its chief disadvantage. I got over this, however, in a manner which I will explain later.

I am quite aware of the advice so frequently given that on no account should anything but real stone be used, but I believe I can show that it is not a necessity 


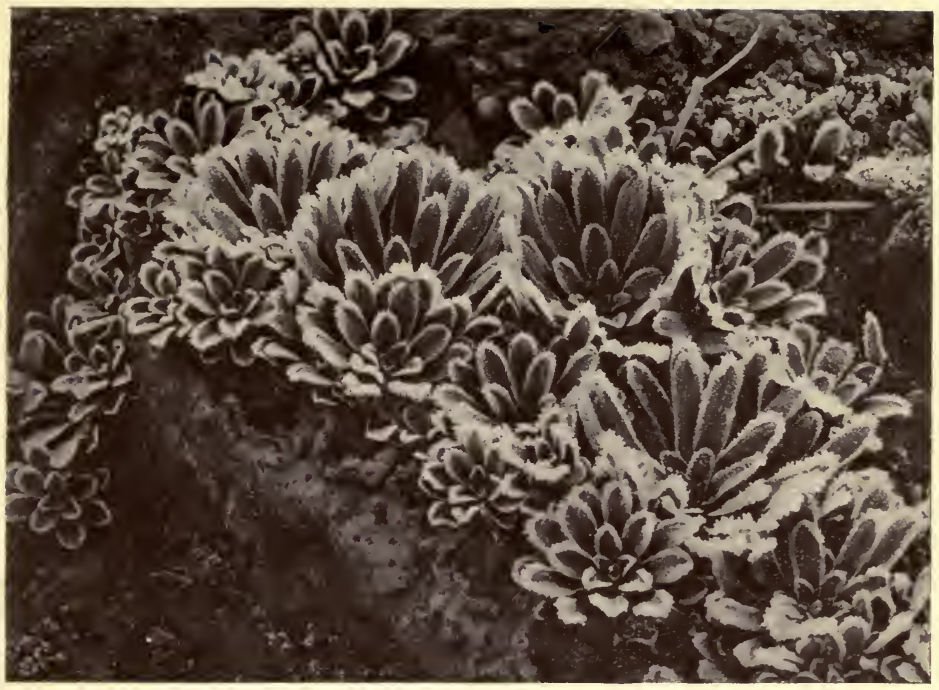

SAXIFRAGA HOSTI UNDER HOAR FROST.

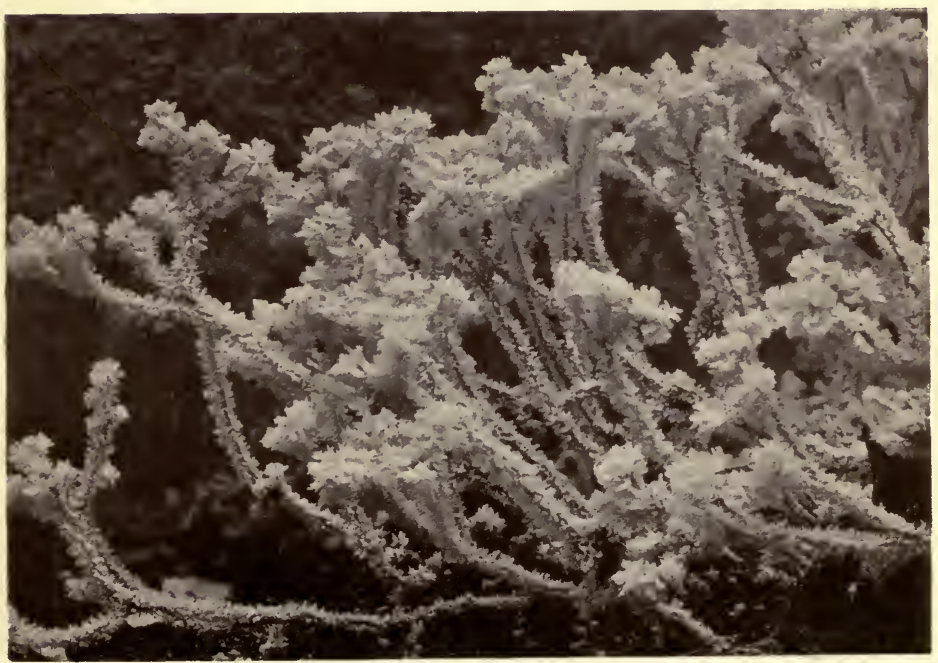

SEED STEMS OF SEDUM TURKESTANICUM UNDER HOAR FROST. 


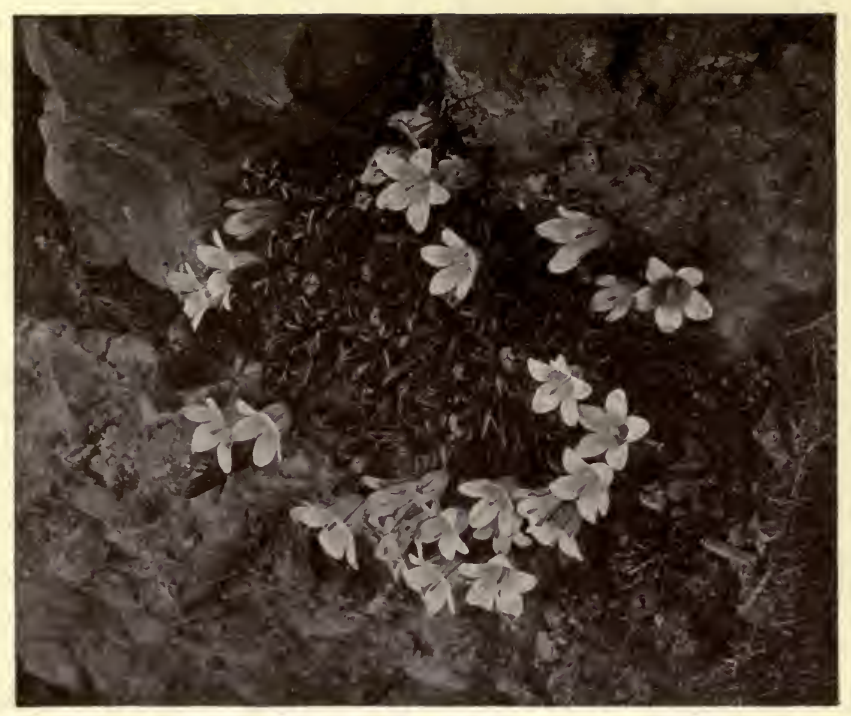

ט

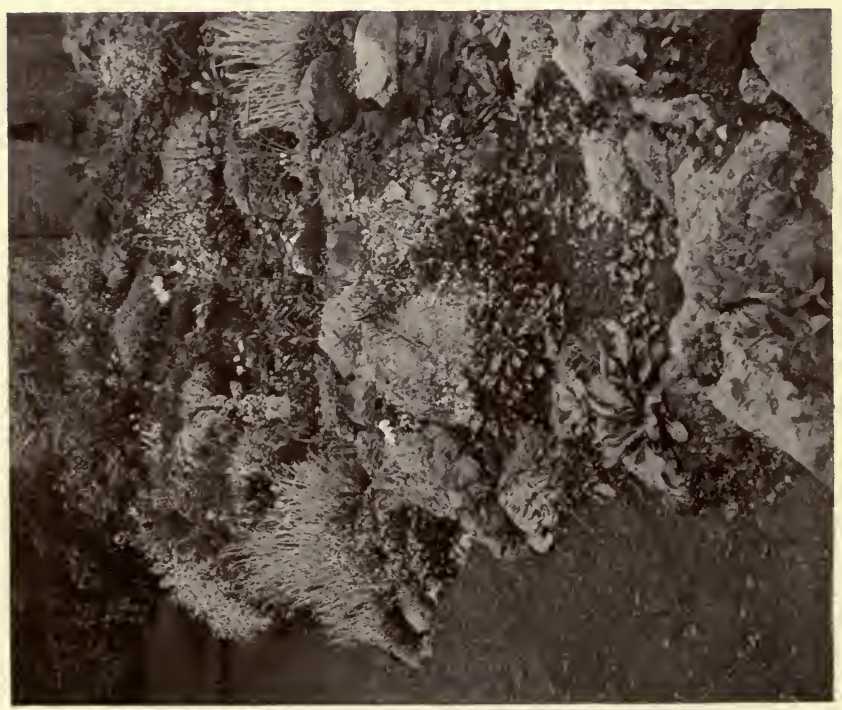

焉 
with the vast number of Alpines, if not indeed with all of them. At the same time I fully appreciate the great advantage that real stone has, so far as its beautiful appearance goes, and, needless to say, I should not consider the concrete lumps if stone were obtainable at anything approaching the same cost. As it was, in beginning my Alpine garden, the absolute necessity of such stone would have prevented my undertaking the matter at all. I can unhesitatingly say that anyone placed as I was, could without any appreciable disadvantage make good the deficiency arising from the absence of stone by using the substitute I speak of.

The initial trouble of heavy soil I mitigated by taking off the surface soil and putting in a layer of " hard core," viz., broken bricks, clinkers, etc., to the depth of six inches over the whole site of the rock garden, after having roughly given the ground a fall to one point. This rapidly conveys the excess of moisture from the soil into which the plants are subsequently to root, to some drain, or it can be made to serve a double purpose, by arranging this drainage vein to terminate at a portion of the garden devoted to a moist or boggy corner, though as I will explain later, it is for some moisture-loving alpines necessary to form what is termed a well drained bog, viz., a place through which fresh water is more or less constantly passing during the 
growing season, and roughly dryer in the winter than in summer.

Before proceeding to give a more detailed account of how I made my garden, it will perhaps be of interest to glance at the conditions under which Alpine plants grow in their native mountains, as this will ensure the best way of simulating these conditions as far as may be in our lowland gardens.

I would here like to point out the immense amount of pleasure I have derived from this tiny space allotted to these mountain plants-every week, indeed every day, in the year sees something of interest happening in the Rock Garden, and though during the winter months flowers are few in number, those that do come to gladden us are valued quite apart from their intrinsic beauty, and are appreciated accordingly.

With this form of gardening when mid February has arrived we are able to start right away with our brilliant succession of blossom which will carry us on, not merely through the hey-day of Summer, with its perfect rainbow of colour-but on to the soft Autumntime, and thence to November and December if the weather be at all kind.

Even in some cases where it seems a great deal of trouble to make some rarer plant feel " at home," the very effort required brings its own reward, and I am sure that with most plant lovers, it is the presence of 


\section{$M Y$ GARDEN AND ITS ENVIRONMENT I9}

plants of all degrees of difficulty that makes this form of gardening so enjoyable, and ever filled with keenest interest.

Lastly, an Alpine garden is a place which our friends are always pleased to see, and are always interested to note the variety of unusual plants growing there, especially if the little points of interest in their structure and adaptation are explained to them. 


\section{CHAPTER II}

\section{PLANNING AND BUILDING}

THE term Alpine plants, though not a very definite one, is generally applied to those plants, usually of dwarf stature, which are found growing on the rich upland pastures immediately above the tree line, on any of the great mountain ranges in the world, and is by no means confined (as it is sometimes thought) to plants from the Swiss Alps.

Plants from lower elevations are often included among those we grow in the Rock Garden, especially such as are of dwarf growth, and in many cases these are of considerable value, though not perhaps so strictly "Alpine " in their habits. These little mountain plants have through long ages adapted themselves to the rigorous conditions prevailing at high elevations, not so much because the conditions are necessary to them, but because they are still less agreeable to larger and coarser growing plants which would, at a lower elevation, over-run these more minute forms.

This conclusion is, I think, amply justified by the 
ease with which we can grow these same plants in our lowland gardens situated little above sea-level, provided we do not allow them to be over-run by weeds and plants of more vigorous habit.

The general conditions prevailing in the high Alps are almost the exact opposite of those we get here in England, and at first sight it would appear difficult -if not altogether impossible-to so modify our surroundings as to make these little mountaineers feel at home.

A factor of primary importance is that the Alpine plant in the mountain is buried to a considerable depth, all through the winter, under a blanket of dry powdery snow, which not only protects the little plants from any sudden variation of temperature, but ensures that they shall be dry about the crown, while the low temperature keeps the plants dormant, and their roots dry also. Owing to the thickness of this snow blanket and despite the great heat of the sun, as it pours down upon the mountain in the Spring and early Summer, it is often June or July before it is able to altogether dissipate the snow, and then the Alpine plants are exposed-not to our variable and uncertain Spring weather-but high Summer time, with ample light, and a high temperature during the day. This is of course conducive to very rapid growth and one of the features which characterizes many Alpine plants, 
is that they burst into blossom almost before the snow is off them.

Coupled with these ideal conditions is the constant supply of cool water from the melting snow still lying higher on the mountains, and this supply is continuous, until by the falling temperature of autumn when plant growth is checked, the frost again grips the mountain, and the supply automatically "ceases, shortly to be followed by the soft wrapping of snow again.

In our gardens, and especially near London, our winters are characterized by periods of soft balmy growing weather, which induce the plant to make " false starts," only to be followed by sharp spells of cold, which damage this soft growth, while usually the ground at this time is at its wettest, consequently preventing the plants ever getting the rest which they are accustomed to. Then, when the hot weather does reach us, the plants are liable to be scorched up owing to the absence of the natural water supply, which in the mountains is so nicely adjusted by the heat of the sun upon the snow!

One other source of difficulty afflicts me here at Woodford, and doubtless many others near to the big city, namely the quiescent periods during our winter, when the air is only gently moving. Then there drifts over to us the grey pall of leaden coloured vapour so constantly hanging above the metropolis, which 
causes to fall upon all and sundry, the smoky, tarry products of the countless London chimneys. These dirt particles stick to the foliage of the little plants, and especially those with silky leaves such as many of the Androsaces, and would in a short time poison them if due precautions were not taken to intercept them.

It will be seen from the foregoing brief description of Alpine versus Garden conditions that it is essential in our Rock Garden to provide for very ample drainage, so as to modify the otherwise sodden state of our soil during the winter, while every effort should be made to prevent the earth drying up in summer, by using pieces of absorbent stone as large as the proportions of our garden will permit, to retain the mounds of earth, which latter should be of a gritty nature, well mixed with pieces of broken stone, or in default thereof, broken brick.

It is a well known fact that lumps of stone in the soil will retain much more moisture than an equal quantity of soil alone, and yet at no time be sodden.

Where possible a water supply should be laid on to various places, so that a small dribble of water can be allowed to thoroughly soak the ground in times of great drought. ' It is worse than useless to sprinkle the surface, though if a permanent supply cannot be arranged, much can be done by the judicious use of a hose. 


\section{THE STORY OF MY ROCK GARDEN}

At the approach of winter, I resort to the following simple expedient to prevent the falling dirt injuring the woolly leaved members of my Alpine family. I take three or four pieces of fairly rigid galvanized iron wire, and bend them to the shape as seen at $B$ in the reproduction of the diagrammatic photograph on page opposite, and in the crook thus formed, a sheet of glass can be kept in position some four inches or five above the plant, sloped in such a way as to cause the rain and dirt to drip off clear of the plant, and yet allow a constant current of air to pass over it-so removing the liability of mildew.

If these glasses are periodically cleaned, I find that the plants are in a healthy and clean condition by the time they should start their new growths-a strong contrast to the unprotected ones, which by that time are usually on the point of expiring, thanks to the continued moist state our atmosphere has kept them in, coupled with the dirt which has adhered to them.

This glass erection is also of great service in protecting winter flowering plants such as many of the Crocus, Galanthus, and Narcissus species, from being damaged by heavy rain. Where the garden is in a position exposed to much wind and these plants are liable to be damaged from this cause also, a development of the foregoing idea can be employed as here illustrated; it is simple to erect, and can be rapidly 


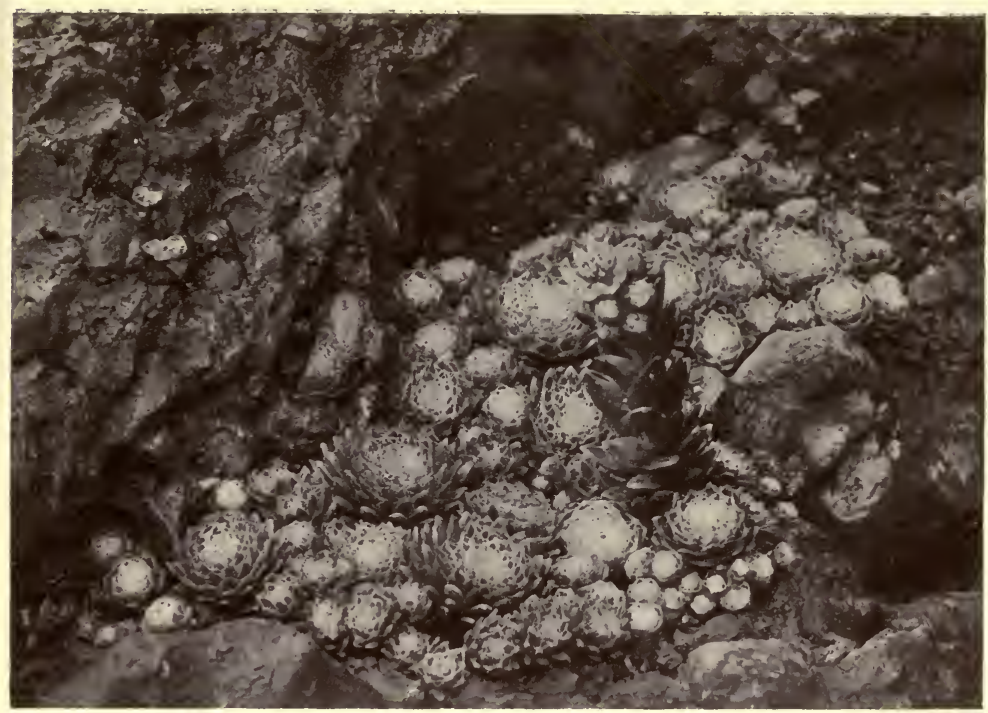

SEMPERVIVUM ARACHNOIDEUM VAR. LAGGERI.

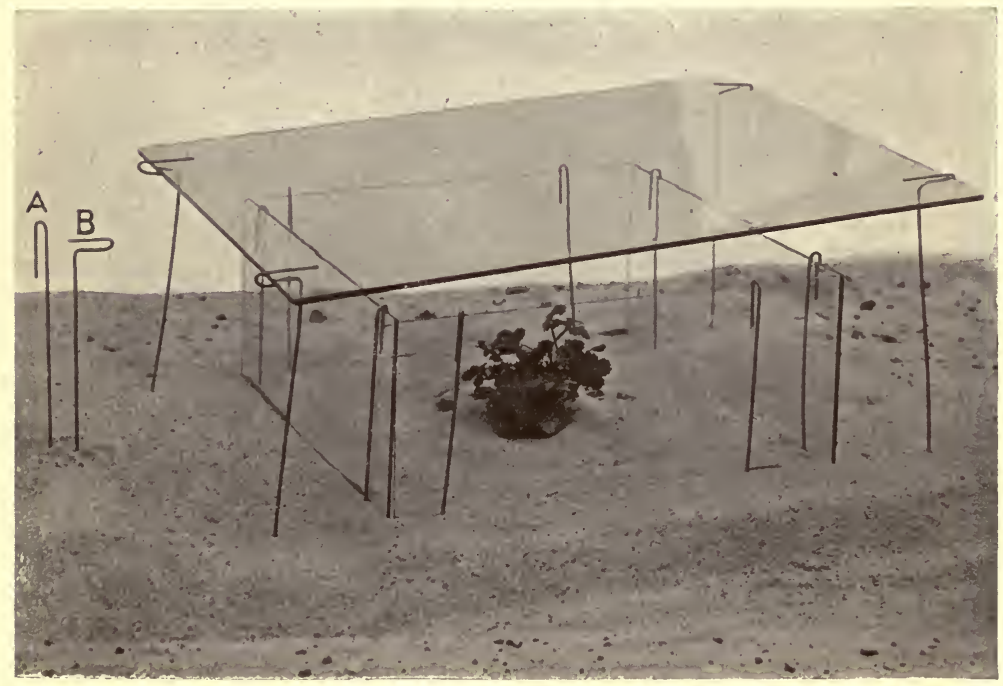



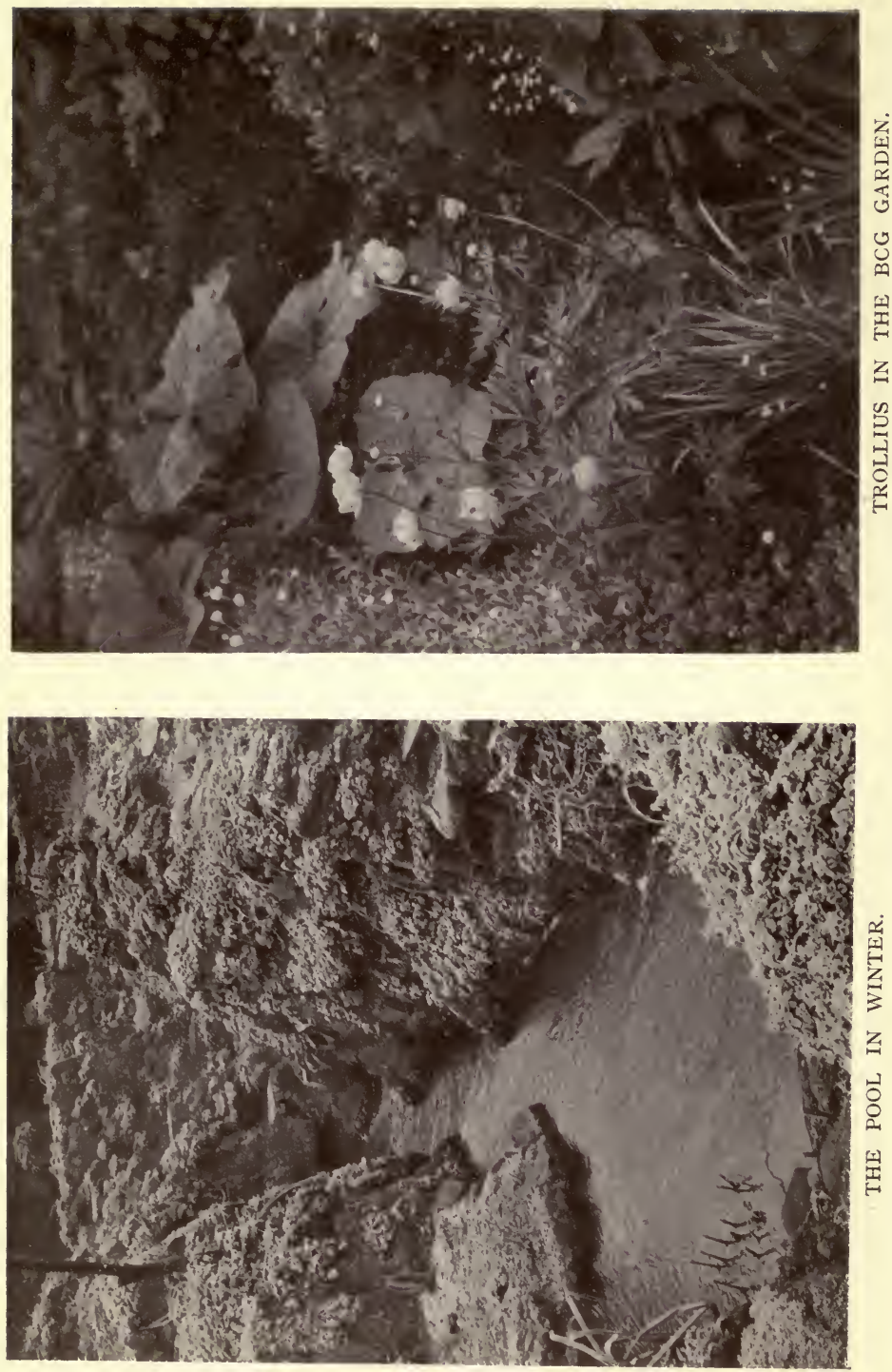
removed when the flowers are over. It will be seen that the side glasses are kept in position by the wires marked A, being just pushed into the soil, while if the roof glass is fairly large, it can be raised high enough above the sides to give ample ventilation, without allowing the rain and wind to drive in to any damaging extent.

When I had made up my mind to form my newly acquired garden into an Alpine one, I proceeded to roughly sketch out its desired form.

For various reasons I was obliged to make a path down both sides of my somewhat rectangular plot, and start the rockery from the inside edge of this. I took considerable care to arrange that the outline abutting upon the path should be as irregular as possible, so as to make it as natural looking as I could.

In this district, despite the all-pervading clay sub-soil, there are in irregular places patches of sandy gravel, and I had reason to believe that one such vein (merely a few feet across) ran near to my proposed rockery. I therefore proceeded to investigate, and much to my delight, at a depth of four feet six inches from the level came upon it, and following it down to eight feet I got into the clay again. What pleased me most, however, was the fact that this little streak of gravel provided me with natural water.

This find decided me to include a small pool in the design-not a formal circular affair, but an irregularly 
shaped one, with an arm leading off from it, at one point, which I proposed should be partially hidden from view by winding round the base of a steep cliff, to give the appearance of a small stream entering the pool between precipitous banks.

The soil I obtained from this excavation-heavy though it was-when well mixed with an equal bulk of sharp road grit helped to form the foundation of the higher parts of the rockery. Before proceeding to shape this, however, I roughly sloped the surface of the whole site slightly towards the pool, which was approximately central in the garden-and spread a layer some six inches thick of "rough stuff" or " hard core" over it. It was upon this that I piled up the soil from the hollow I was making.

I allowed the earth to accumulate to a considerable degree, roughly in the undulating form I desired the rockery finally to have, thereby getting a better idea of the design than I possibly could from a drawing.

When I had excavated what I considered sufficient to form the pool and its adjoining arm I proceeded to the building proper. What was to be the floor of the pool I rammed firmly, and after making it slightly hollow, paved it with old bricks, and from the edge of this paving I started building up the somewhat steep sides with concrete lumps before mentioned, and which I will hereafter call my "stone." 
Each piece was very firmly placed and carefully wedged, so as to make it immovable, the soil being well rammed in behind it to knit it all together. This I continued all round the sides of the pool till I reached nearly to the permanent water level, which I had previously ascertained.

At two parts I then ceased building, as there I had proposed to make a bog bed, where water loving Primulas, Iris and Saxifraga peltata could be planted with their toes in the water but their crowns above. The retaining wall about these places I completed to six inches above the water level, with stone lumps set in cement, and instead of filling in with ordinary soil, I put in broken peat blocks and peat moss, to the depth of eighteen inches, topped with finer peat, sand and leaf-mould, in about equal proportions.

As soon as the other parts of the pool side, except the steep cliff, had reached just above the water level, I altered the angle of building, which hitherto had been one of about sixty degrees, to one more approaching thirty-five degrees, but varied in such a way as to form buttress-like shoulders, with valleys between, so giving an irregular and natural appearance to it.

Above one of the bog beds, before mentioned, I constructed four others, each one higher than the preceding, in the form of terraces, and in these cases, since they were to form well-drained bogs, that is, 
places where spongy soil exists, constantly wetted by water passing through it, and which, by the cutting off of the water supply, could be rendered comparatively dry in the winter or resting season, I made the floor water-tight with a thick coating of clay well puddled into the trodden bottom. The front and sides of each of these were built up in just the same way, using heavy lumps of stone well wedged together and fixed with cement, since the soil behind them would be soft and spongy and so afford no support to the stones themselves. These compartments were filled in with coarse peat at the bottom, and the before-mentioned compost of peat, sand and leaf-mould.

When I had arrived at a point a little above the normal level of the ground, I started the outline from the path side, arranging for it to fall into small "bays" here and there, separated by promontories or buttresses running down into the path, so as to give it the appearance of springing out of the latter in a natural way-or as though a somewhat level place among the rocky ground had been utilized to form the path. This irregular outline is illustrated by the reproduction facing page I7. Particular care was taken to select good looking stones to form these promontories, since they would be to a certain extent visible, even when the rest of the garden was well clothed.

The compartments, if one can apply that name to 
those irregularly shaped beds between the various tiers of rocks, were arranged as far as possible of different shapes and heights, and I took much care to build only from the completed and thoroughly solid portion upwards, towards the unfinished part, and in each case the soil was well hammered and trodden down behind each stone. Time after time I placed the various stones, first upon one side, and then upon another and viewed them from a little distance, to make sure that their outline was in conformity with the effect I desired.

I found it best to ram down the soil in the finished compartments, and afterwards slightly slope the place the next stone was to occupy, downwards and towards the back; this gave the new stone a seating which would cause it to slope inwards and downwards towards the soil, and thus be firm and solid, enabling one to put his whole weight upon any one of the stones so placed, without the slightest risk of moving it.

It is a point too often overlooked in rockery building that the stones should be used to retain the soil, and not the soil to retain the stones! Too much emphasis cannot be put upon this point, as no end of trouble will follow any deviation from this rule.

, Here and there, at convenient places, I arranged either flat-topped lumps of stone, or else stone slabs with irregular edges, to form rough stepping places, 
so as to be able to easily reach any desired part of the rockery to attend to its little inhabitants, without risk of treading upon surrounding plants, which might easily be done were not definite spots allotted for this purpose.

At one point I arranged a series of rough steps in a winding manner-so that here and there they disappeared behind small bluffs-and having made them water-tight with cement, I was enabled to introduce water at the upper part and allow it to run down, in a miniature cascade, to the pool at the foot; in the hot summer weather this looks very pretty, besides leaving in odd places wee pools of water, to which our feathered friends of the garden flock to drink and bathe.

At various places I built steep shoulders of rockery, dropping abruptly to the normal level of the surrounding part, and in the crevices of such shoulders, plants like Saxifraga lingulata, longifolia, cochlearis minor (and in moist shady corners Ramondias and Haberleas), I found thrive-all these plants prefer a more or less vertical position, where their rosette is placed on edge, as it were, thus allowing all moisture to rapidly run off, instead of hanging about the crown. The actual method of planting, which is best done at the time of building I will enter into later.

At one side of my Rock Garden, facing south-east, I made the soil much more gritty, right from the 
bottom, and at this point I formed a collection of the dwarfer and more choice Saxifrages such as Sax. burseriana, marginata, rocheliana, Elizabetha, Salomoni, Ferdinandi-Coburgi, apiculata, lingulata lantoscana, the charming little Woodruff Asperula suberosa, and that lovely gem Edraianthus serpyllifolius.

To make the soil here free enough, I mixed with it more than half its bulk of broken brick passed through a half-inch sieve, while its depth was about fifteen inches; other ingredients being well-decayed leafmould, old sifted mortar, good loam, and sand, in about equal proportions. This, when well compacted, proved a very happy rooting medium for these little closegrowing plants, the Edraianthus being placed in a crevice where its roots could wander away in a semihorizontal direction, and its crown be protected from an undue amount of moisture. The illustration facing page I7 gives a good idea of the appearance of the plant when in flower.

The blossoms are of a rich purple, rising almost stalkless from a dense cluster of small deep bronzy green leaves. Its curious habit of opening its flowers on the outside of its more or less circular tuft is well exemplified. I am indebted to the proprietors of The Garden for permission to reproduce the two plates, since I passed them the copyright some time since. 
In one or two other places the "bays" opening out near the path I devoted to semi-bog plants, simply making a depression, clay-lining the bottom, and filling in with spongy soil, where such subjects as Primula farinosa, P. frondosa, P. capitata, P. Cockburniana, Violas, cornuta and biflora, Aquilegia alpina-and a variety of smaller plants, which might easily be overlooked if far from the point of view, could find a suitable habitation.

Needless to say, I do not encourage every visitor to use the stepping stones about in the rock garden, ladies' dresses especially having a way of brushing against the smaller plants bounding these steps, in a manner liable to damage them. I have endeavoured to render such close inspection of the inner part of the garden unnecessary by growing there the rather larger plants and accumulating the small ones nearer the path and so close under the eye.

If the reader has followed the foregoing, it will have been evident that it is to a large extent necessary to work round one's Rock Garden bit by bit, in building, not carrying up any one part to a great height till the adjoining portions have been raised, and so on-thus forming a solid foundation to rise from.

The exact conformation of one's garden must of course be largely a matter of personal choice, but if nothing very heroic is attempted, and as far as may be, 


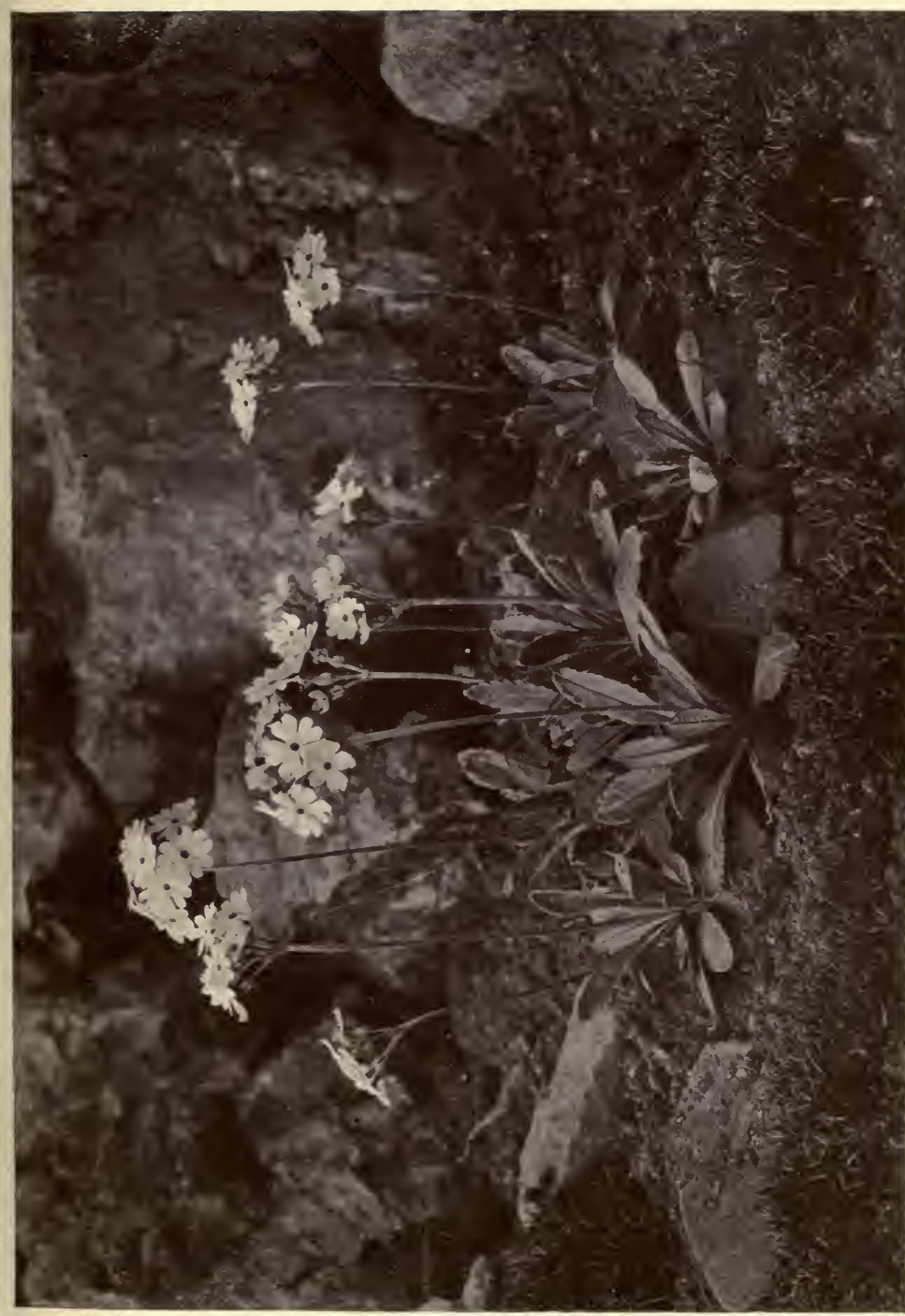

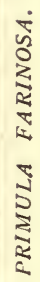



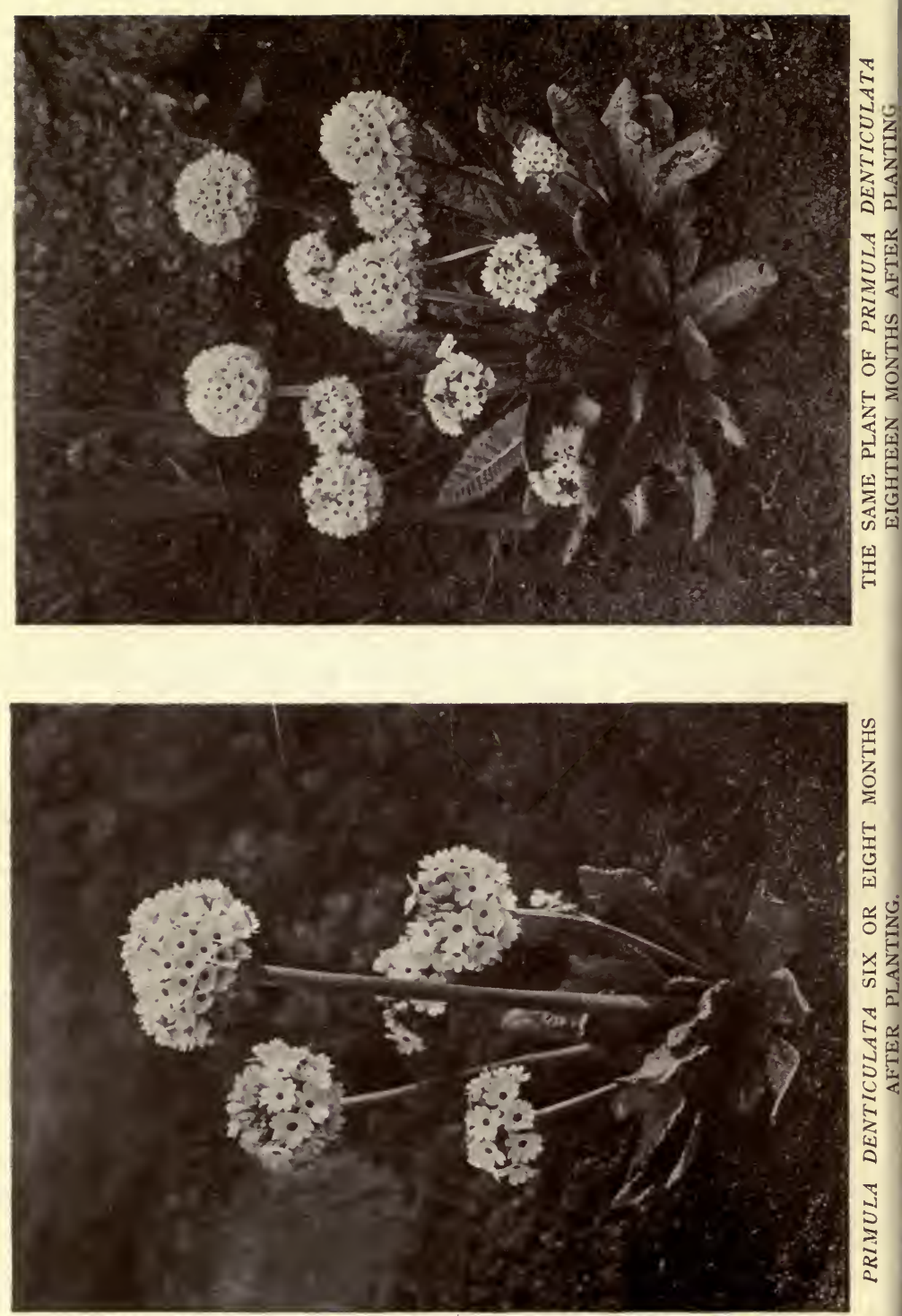
natural formations are imitated, or at least not abused, the result will usually be satisfactory-especially if it be continually borne in mind that the rockery is primarily-indeed solely-for the cultivation of plants, many of which are deep rooting, and require ample, well-drained soil into which they can ramify.

I may here say with advantage to any who are thinking of starting a Rock Garden, that at an early date in my Alpine plant career, I was given that splendid book "Alpine Flowers for Gardens," written by that veteran plant lover, and Alpine plant enthusiast, William Robinson. No one who has used it as their "guide, philosopher and friend," as I have done, can find anything but praise for it, both in its sound principles, and the charming manner in which it is written. To read it is to have become an Alpine plant lover at once! One other point I ought to mention before leaving this part of the work, and that is, with rare exceptions, on no account should any upper stone overhang a lower one. This with the beginner is I think a frequent cause of failure, it not being realized that such a formation entirely prevents any water in the form of rain from reaching the roots of a plant in such a position, unless the overhanging stone be quite a small one-in which case it would probably fall over altogether. 


\section{THE STORY OF MY KOCK GARDEN}

Each higher stone, even in an almost perpendicular place, should slightly recede from the one beneath, thus exposing a "lip" which will catch the falling rain and convey it into the soil, owing to the inward tilt with which each stone is laid.

Occasionally such a position may be permissible for such plants as dislike overhead wet-as for instance Eritrichium nanum, some of the Erodiums, Senecio incanis var. Persoonii, and Primula Allionii, but then precaution should be taken that moisture is conveyed to their roots in some way. It is on the whole advisable to keep away from this form of building, until one is familiar with the requirements of such " touchy" plants as really need it.

I found that with careful selection every part of the rockery could be planted and to a great extent covered with Alpines. Even in such a little garden as mine I was able to provide positions in practically every aspect-from deep shade on the north face to full sun on the south. In some instances it is policy to plant certain varieties of say Campanula in partially shady positions, as well as in full sun, and thereby secure a longer period of blossom, since those in the cooler spots are just coming into flower as the fully exposed ones are passing.

It is advisable also to plant at the lower portion of the rock work, near to the path, especially 
where the former is of any height, such things as do not greatly mind being trodden on somewhat, and are fairly vigorous, such as mossy Saxifrages, Sax. umbrosa, Arabis, Sedum spurium, as it is very annoying to get some choice plant damaged by an accidental kick.

Where the rock edging to the path is low, I find it useful to allow dwarf carpeting plants like Arenaria balearica, A. caspitosa, Acaena in variety, and Cotula squalida to scramble over the edge, and grow carelessly on to the path itself-it takes off the rigid outline of the path and gives a very natural appearance to the whole. When they get too much in the way it is easy, with care, to take off portions in such a manner as to leave no mark of the devastating hand, and friends are always delighted to " take charge" of such surplus plants.

As I mentioned earlier, I was fortunate in having no trees of any size in my garden, since not only do they rob the soil to a considerable extent, but their branches seriously curtail the amount of light falling on the plants, and where one's garden is small, and especially when not situated in the open country, this is of immense importance, since the brilliancy of the light is already considerably modified by the proximity of buildings, to say nothing of the more or less ever present smoke vapour. In addition to this, the drip 
36 THE STORY OF MY ROCK GARDEN

from the branches, during the winter especially, is very detrimental to the mountain plants.

If at all practicable, any trees near enough to a proposed Alpine garden to harm it should be removed, or at least the overhanging branches taken off. 


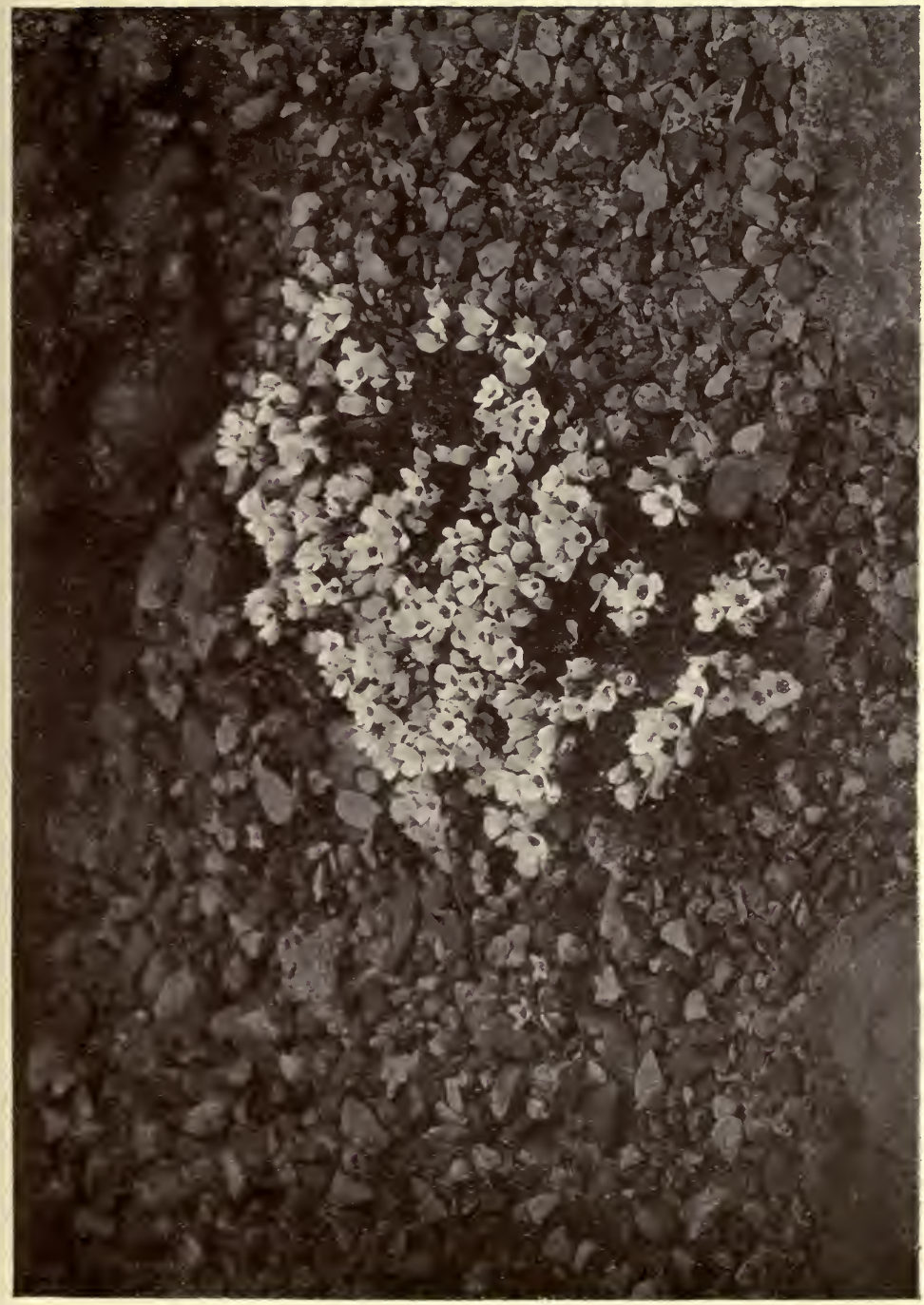

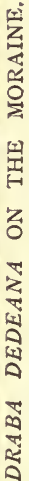




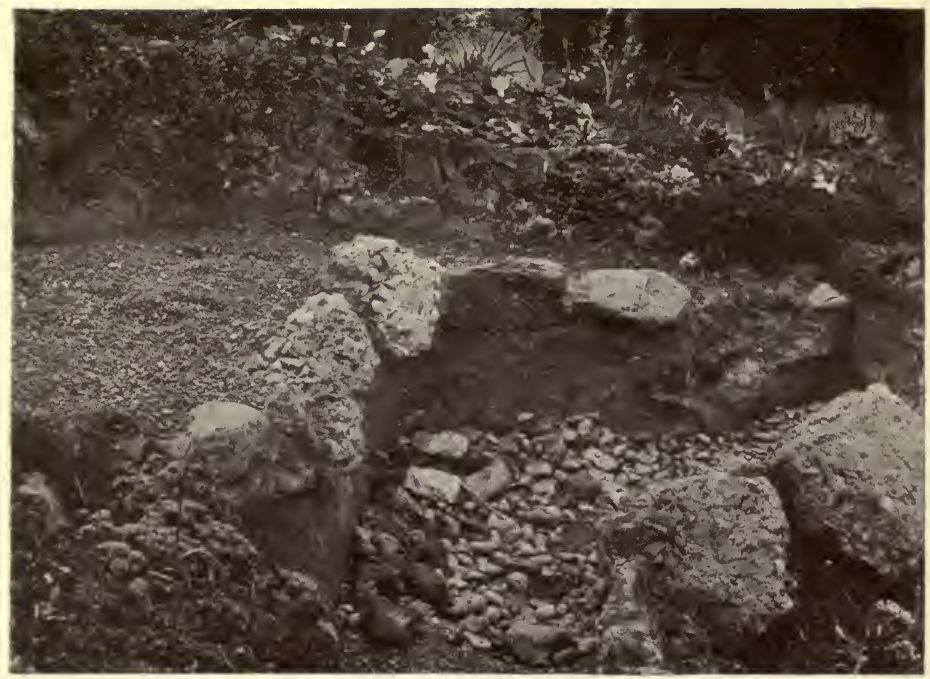

THE MORAINE IN COURSE OF CONSTRUCTION.

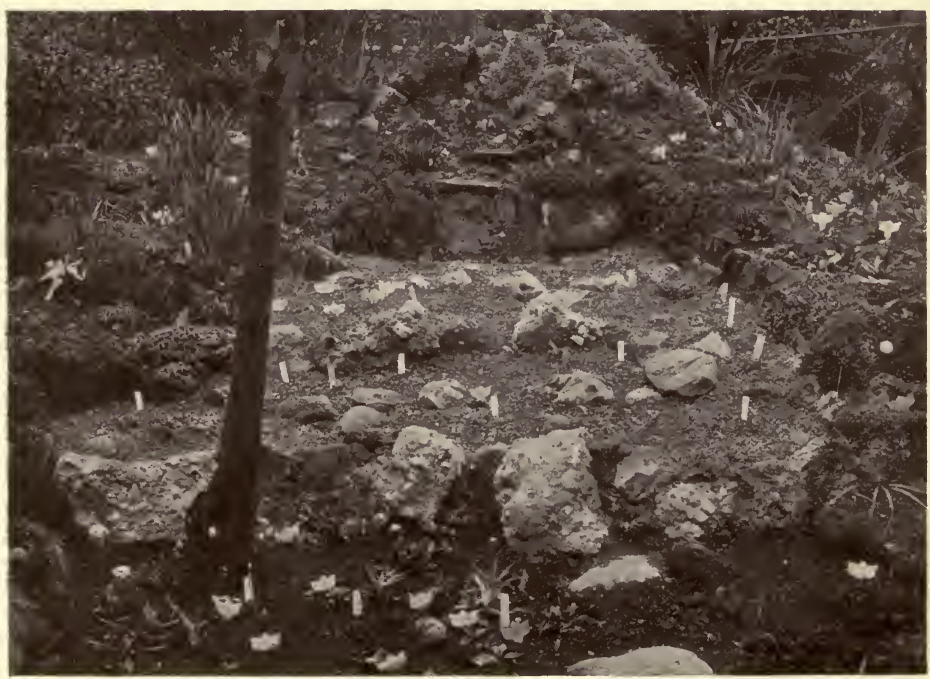

THE MORAINE COMPLETED. 


\section{CHAPTER III}

THE MORAINE

BEFORE wandering far from the structural matters of the Rock Garden, I will endeavour to give a description of that somewhat recent adjunct, the Moraine-which has now become such a prominent feature of many Alpine gardens. In my own case my attention was not directed to it till some time after I had built my Rock Garden, so that its inclusion meant an alteration in the existing arrangement.

For the benefit of those not already acquainted with a natural moraine, I will outline what I conceive to be its chief features.

At the foot of the glaciers or ice rivers, which come down from between the higher peaks, are found vast accumulations of stone detritus-fragments which have been torn and broken away from the glacier bedcarried down with the descending ice, and deposited at the place where it melted. These heaps or ridges are usually found on sloping ground, and are often piled up at an acute angle. 
Through this mass of stone chips-varying in size from large blocks weighing tons, to quite small gritflows during the summer a constant supply of ice-cold water from the melting glacier above, carrying away with it any fine particles of soil which may have existed among the stones. Upon such soaking shingles certain plants thrive, and indeed seem disinclined to grow satisfactorily elsewhere!

As in the case of plants which jewel the short turf of the Alps below the glacier, the winter conditions higher up are similar, the outflows of the glacier freeze up, and so stop the water supply, while the moisture held in the absorbent mass of stone gradually drains away, leaving the plants comparatively dry. Upon this descends the snowy mantle from the wintry sky, securely wrapping up in its soft folds both the moraine and its little inhabitants, until the hot sun of the following summer thaws them out again.

This release from their winter quarters, however, often does not take place until July, so that the period during which they can flower and perfect their seed is short indeed.

It will be seen that the open nature of the stony "soil," if we can use this name for the smaller stone chips, ensures quick drainage, and the likelihood of a sufficient amount of fine sandy particles accumulating in any place to materially check this rapid drainage, 
is reduced to a minimum by the constant percolation of the melting ice water through the whole mass, while complete winter rest is assured by the draining away of the moisture, due to the cutting off of the supply and the thick blanket of snow which covers the plants.

It would at first sight seem difficult to reproduce these conditions in our lowland gardens, but with care and some thought it is quite possible to imitate them sufficiently well to induce many moraine plants to flourish and flower profusely, even in a suburban garden like mine.

The method I adopted was as follows:- Since most of the moraine plants grow in an open situation, I selected a portion of my little garden, fully exposed to the sun and where the Rock Garden rose somewhat abruptly. Into the side of this hummock, by digging out the soil, I formed what were practically two tanks, one above the other, some five feet long, by two feet wide and deep, and watertight to the depth of six to eight inches, with the floor sloping towards the front.

The operation consisted of well ramming the floor, and putting in three inches of cement concrete, while the sides were built up with brick and cement, till nearly level with what was to be the surface of the moraine-when they were topped with good-looking 


\section{THE STORY OF MY ROCK GARDEN}

pieces of stone, which would be visible when the whole was completed.

At a convenient place in the front,-and where the floor was at its lowest, I inserted in the retaining wall of each compartment a valve which could be readily opened and closed.

Being anxious to complete the moraine by a certain time, as I had to leave home for a while, and having no suitable metal valve to hand, it occurred to me that the upper part of a champagne bottle, which is of very tough glass, would make an excellent substitute. The difficulty was, how to cut it !

After some consideration I hit upon the following plan, which answered admirably. Stand the bottle in an ordinary bucket and fill the latter with cold water, till the liquid stands at the height the bottle is to be severed. Now take out the bottle and wipe it dry, and proceed to heat over a gas flame just that part where the cut is to be, keeping the bottle rotating the whole time. When very hot replace the bottle rapidly in the bucket of water, and with a "ping " the upper part will leave the lower, exactly at the water line, as cleanly as if cut by a diamond-due of course, to the rapid contraction of the heated portion below the water! The reason for first filling the bucket, with the bottle in position, is to ensure the water being at the right level, so that the heated bottle can be hastily 


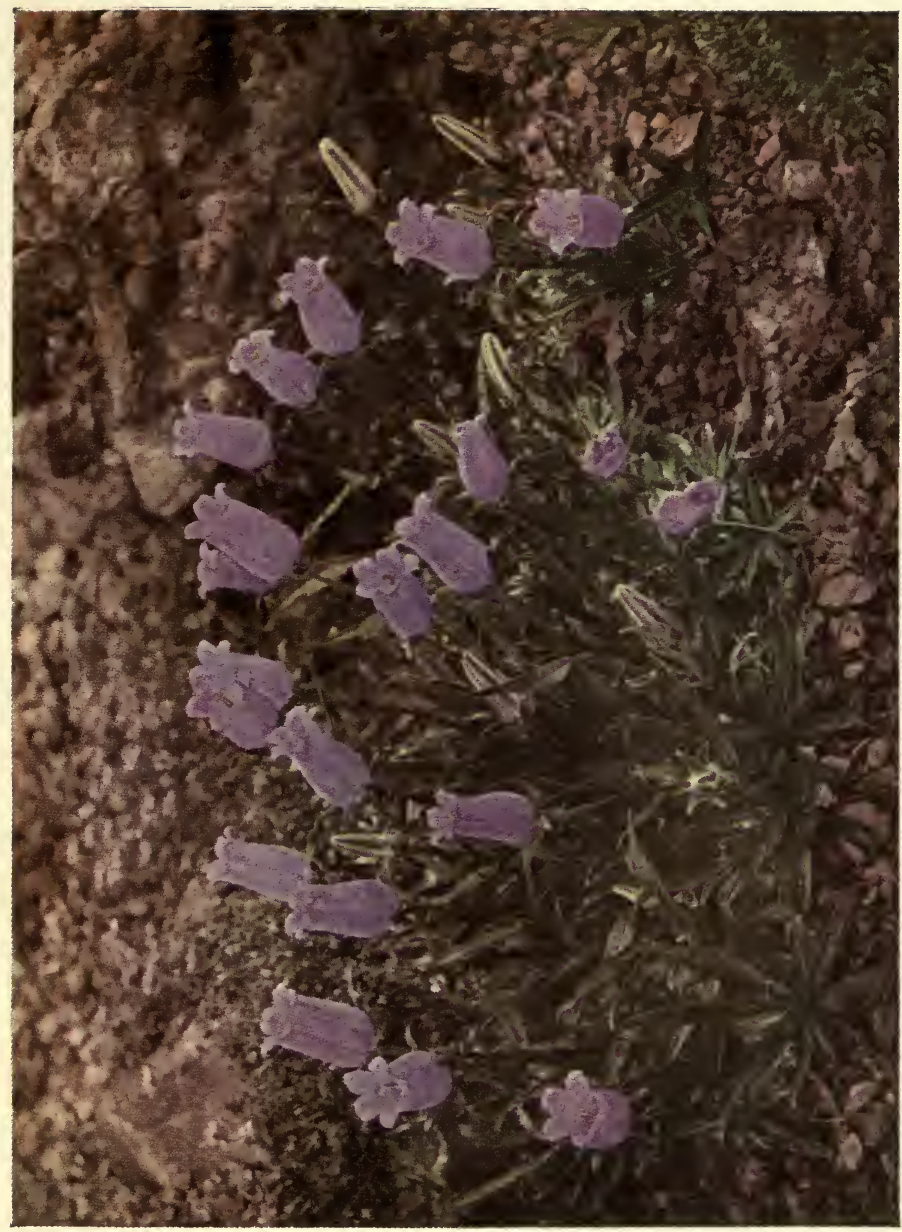



plunged automatically into the same position as it previously occupied, without having to consider how far down it should go.

To return to the moraine, however ; this valve, on a level with the lowest part of the floor, I carefully gauzed with perforated zinc on the inside to prevent it by any chance getting choked up. At six to eight inches from the level of the floor I arranged small apertures in the retaining walls between the topping stone.

It will thus be seen that when I allowed the water to enter the upper compartment, the valves being closed by corks, the water would trickle into the lower one through the six inch overflow holes; from this it would escape in a similar way, and as immediately beneath this my series of bog terraces commenced, the water would supply that also! When, however, I opened the lower valves no water whatever would remain in the compartments, but drain out, owing to the inclined floor.

When I was sure that this part of the scheme was working satisfactorily, I proceeded to put a layer six inches deep of broken brick rubble about as large as my fist into the bottom of each compartment. Upon this I placed a layer two inches thick of stone of the required size to just cover over the interspaces between the lower coarser stuff and thus prevent any finer soil from sifting in between them to a serious degree. 


\section{THE STORY OF MY ROCK GARDEN}

On the top of this layer I placed the moraine soil proper, consisting of sandstone chips, largely augmented by broken brick and tile, which makes an excellent substitute when sandstone is at a premium. I put the whole of these chips through a half-inch sieve for the lower portion of the soil, and a quarter-inch sieve for the upper layer, while to eliminate the dust particles from among them, which would very readily clog the drainage, I passed the whole through a one-eighth of an inch sieve. By this means I introduced into the moraine clean sharp grit only.

Into the upper six inches of the moraine soil I mixed the merest suspicion of well decayed leaf-mould, probably about one to fifteen parts of stone chips. One of the illustrations on page 37 gives an idea of the appearance of the two compartments, when the bottom layer of "rough stuff" was in one, and the bulk of the finer chips in the other. It also shows the dividing wall topped with decorative pieces of stone, and illustrates the irregular form of that wall, which allows the topping stones to make an irregular line, when the moraine is completed.

The second illustration on the same page gives an idea of the appearance of the moraine immediately after it was finished and planted. Most of my moraine plants being very small, I fear there is visible in most cases more label than plant, at this early stage. My water 
supply was introduced at the top of the steps just distinguishable in the last photograph referred to, and trickled over the steps and spread itself out over the moraine.

In this little moraine I grow, among other plants, Dianthus alpinus, that brilliant little plant, from the Eastern Alps and Carpathians, D. glacialis, Anemone vernalis, Douglasia vitaliana, Ranunculus glacialis, and alpestris, Sax. aizoides, and its beautiful variety, atrorubens, Sax. oppositifolia, Sax. Aizoon, which looks particularly happy nestling among the stone chips, Edraianthus serpyllifolius, E. dinaricus, Draba aizoides and dedeana, a photograph of which appears on page 36 . I think it illustrates how freely this diminutive green hummock of leaves covers itself with its pure white flowers, so as almost to hide the foliage. The wealth of blossom is also accentuated by the bare surroundings of stone chips. It seems almost incredible that the roots of such a plant can obtain enough nourishment from so barren and "poor" a soil.

Among other plants I tried in this moraine were Aquilegia alpina, Viola calcarata, Hypericum reptans, and Sax. retusa, but they do not seem so much at home as many others.

That charming little Pyrenean Draba, often called Petrocallis pyrenaica, thrives amazingly among this débris, running about among the chips in a striking 
contrast to the way it languishes in any other soil I have tried it in. When in April it is covered with its dainty lilac coloured flowers, so as to hide the close tufts of growth, it is indeed a pretty picture, and well deserves its name "Beauty of the Rocks."

In this wee moraine I also grow successfully such gems as Campanula cenisia, only half an inch high, with large solitary terminal flowers; Camp. excisa, with its thread-like stalks; Camp. Zoysii, with its bells, so curiously constricted at their mouth; and perhaps most showy of all, Camp. Allionii, which thrives at such a rate that I am removing a part of the clump. (See page 40.) Under any other than moraine conditions I have never been put to this trouble before, this somewhat coy plant usually removing itself all too soon. Here too, thrives Silene acaulis, the very picture of happiness, nestled in a snug compact hummock among the chips.

The illustration opposite shows how freely it blossoms with me, despite the proximity to London. I fully appreciate that the flowers are much more sparse than on the lovely clumps eighteen inches or more across, which we find in the Swiss Alps, one mass of pink, but I have never yet seen it flower in this country so profusely as in the mountains.

One other plant in my moraine I must not fail to refer to, and that is the one illustrated on page 45 , showing that gem Eritrichium nanum. A mono- 


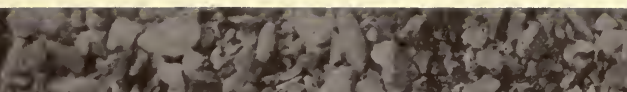
QP.

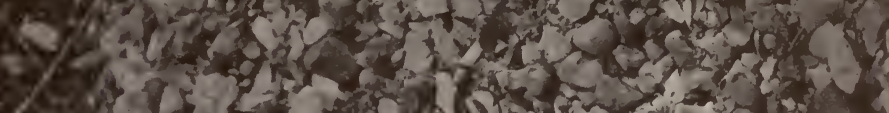

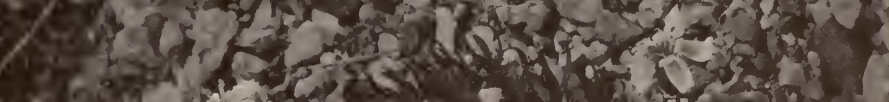

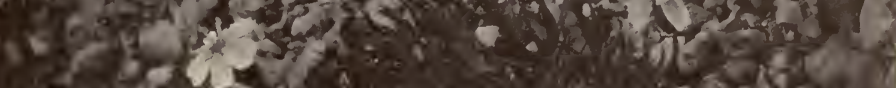

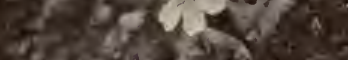

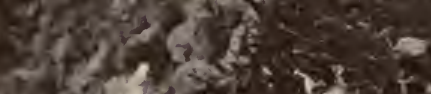
If) 1 is 2

$4 x=15 \%$ to (1) $122^{2}+x^{2}-96$ in :3 80 (1) is - ? $^{2}$ al 1 (3) wha d a

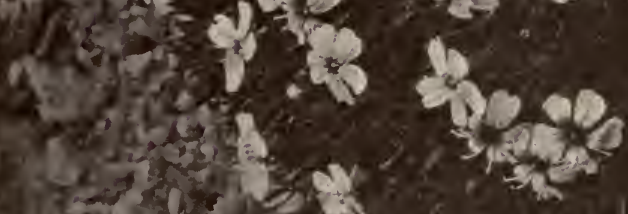
Lin $x$ Tow 3 1.5 43 ? 45 告

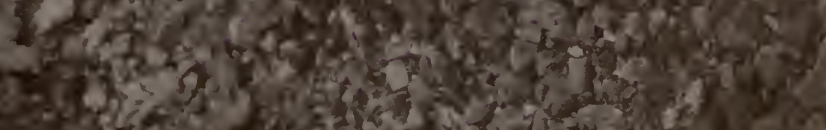
s.2. 


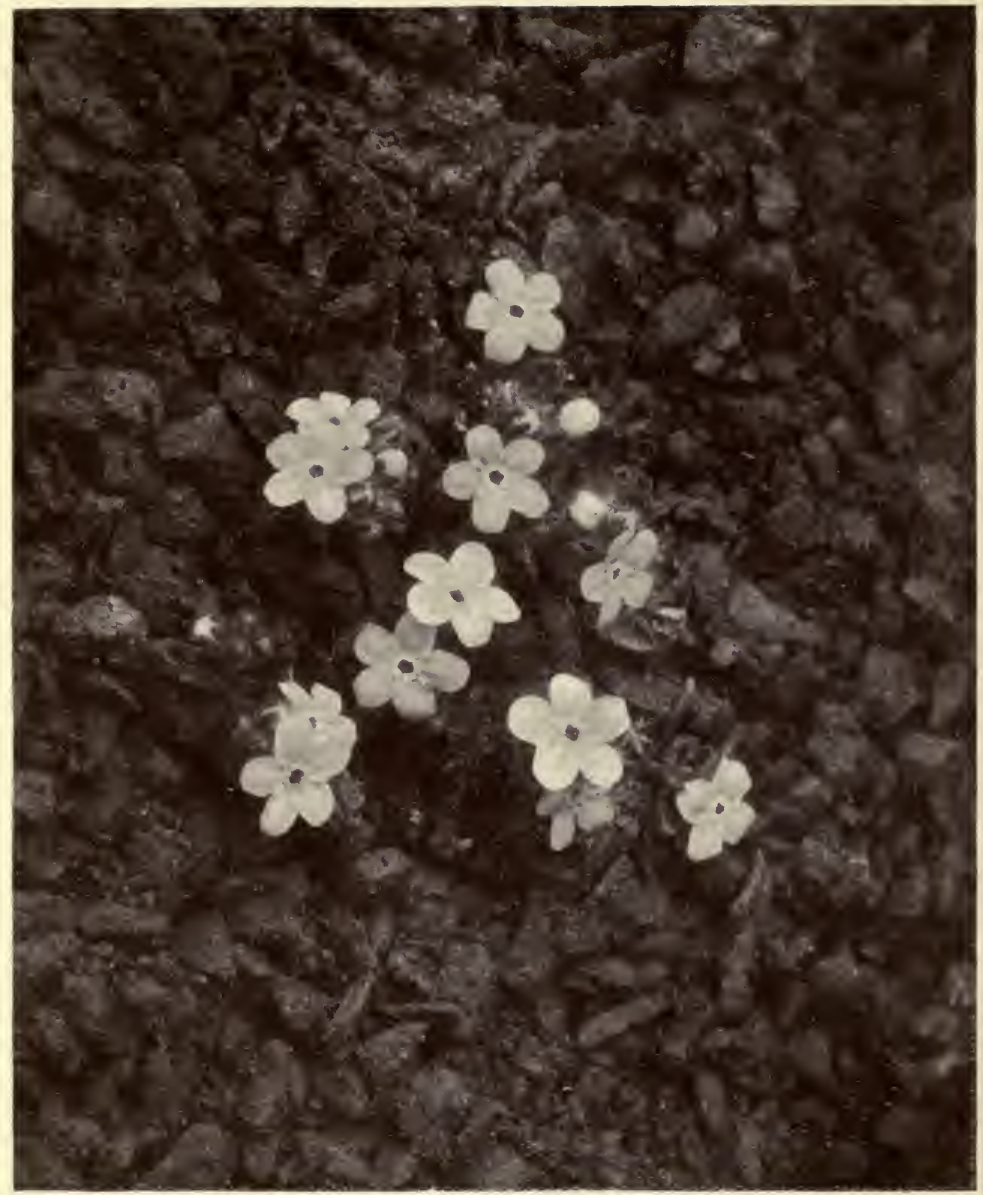

ERITRICHIL.M NANUM ON THE MORAINE. 
chrome reproduction can give no idea of the brilliancy of the flowers of this lovely little plant, which are of a dazzling azure blue with a yellow eye. The leaves arranged in tufts are extremely small and covered with fine hairs. The whole plant is scarcely one half an inch high. It is reputed to be one of the very difficult Alpines to cultivate, and naturally it is therefore the desire of the Alpine gardener to be successful with it. It comes from very high altitudes and intensely dislikes moisture on its foliage.

Some measure of success will usually attend planting it, as in the moraine it will have ample root moisture all through the growing season, with a perfectly dry crown when dormant-it is also advisable to arrange either a partially overhanging stone, or a piece of glass, in such as way as to throw off the bulk of the rain, even in summer time, and such is of course a necessity during winter. Some growers also advise covering the tufts with fine dry silver sand during the dormant season, in addition to the foregoing protection against wet.

I was extremely pleased to see my little plant flower so well last spring, and one of the most humorous comments I ever heard in reference to my garden was made in connection with it. I was showing it, with great pride, to a friend, who was not an Alpine plant grower, and explaining to him how difficult a plant 


\section{THE STORY OF MY ROCK GARDEN}

it was to grow, and that it was allied to the forget-menots, when he surprised me with the following heartless remark- "Oh, well, it would not matter much if you could not grow it, would it ?" To those who have tried Eritrichium nanum my feelings can be better imagined than described!!

On the larger stones which protrude through the moraine soil, I allow Arenaria balearica to spread its green film of growth ; it is one-eighth of an inch highand very pretty it looks, especially when covered with its pure white blossoms, on one inch high stalks, closing each evening and re-opening the following day. Care must be taken, however, that it does not obtrude itself on the choicer plants, as in the moist shingles it grows very rapidly.

Two other very pretty and indispensable, plants to wander over vacant spots on the moraine are Linaria alpina, with its purple and orange snapdragon like flowers, and the wee violet cress Ionopsidium acaule. With me they both sow themselves, and come up most readily, and are easily removed whenever necessary.

From my experience, I believe that the remedy for many of the Alpine plants that are somewhat uncertain and "miffy" in the Rock Garden, is to be found in the moraine.

I believe that to a large extent the soil in the Alpine garden itself, could with great advantage more nearly 
approach that of the moraine, than is usually the case at present-certainly my experiment in the corner devoted to Saxifrages is proving most satisfactory.

Other plants which I have recently added to the moraine, or propose so to do are:- Ethionema coridifolium, Androsace Laggeri, Anemone narcissiflora, Campanula alpina, Camp. morettiana, Camp. pulla, Dianthus neglectus, Gentiana bavarica, Geum reptans, Gypsophila cerastioides, Houstonia carulea, Lychnis alpina, Papaver alpinum, Potentilla nitida, Primula integrifolia, $P$. glutinosa, $P$. viscosa, $P$. minima, Ranunculus glacialis, Thlaspi rotundifolium, Trifolium alpinum, Viola biflora.

I find it advisable when inserting new plants into the moraine, to dislodge such of the soil as may be adhering thereto, without unduly disturbing the roots, and especially to see that the neck of the plant is clean and free from soil.

When March arrives I usually close the bottom valves, and if the season seems fairly normal, I reintroduce the water about the end of the month, though this is a matter which must be decided by the weather at the moment, it being borne in mind that when once the plants are 1eally moving after their winter rest, they must not want for water until the following September or October.

When November is approaching, with its clammy, 


\section{THE STORY OF MY ROCK GARDEN}

dirty weather, I erect the sheets of glass before referred to over all the hairy-leaved plants, and such others as I consider require it, which include the greater part of the moraine subjects. It is, I think, better to err on the side of protecting those that do not require it, than the reverse, since I have never known the glass to harm a plant.

I usually dust over the surface of the moraine once, or possibly twice a year the merest sprinkling of well decayed leaf-soil, which in a few days drifts in between the chips.

If any of the plants seem inclined to grow out of the soil, and become "leggy" - a feature which is rare on the moraine, where the conditions seem to induce a tight habit of growth-the straggling pieces should be coaxed down and a layer of chips placed over them, leaving just the extreme green point visible. A close cushion form of growth I find results from this treatment.

In conclusion, I must say that in proportion to its area, I think the moraine contains more of interest and beauty than any other part of my little garden, and I have no hesitation in saying that the initial work entailed in getting it established is repaid a hundred times, by being able to grow in it plants which both for beauty of form, colour, and general habit of growth, cannot be excelled by any other hardy ones. 


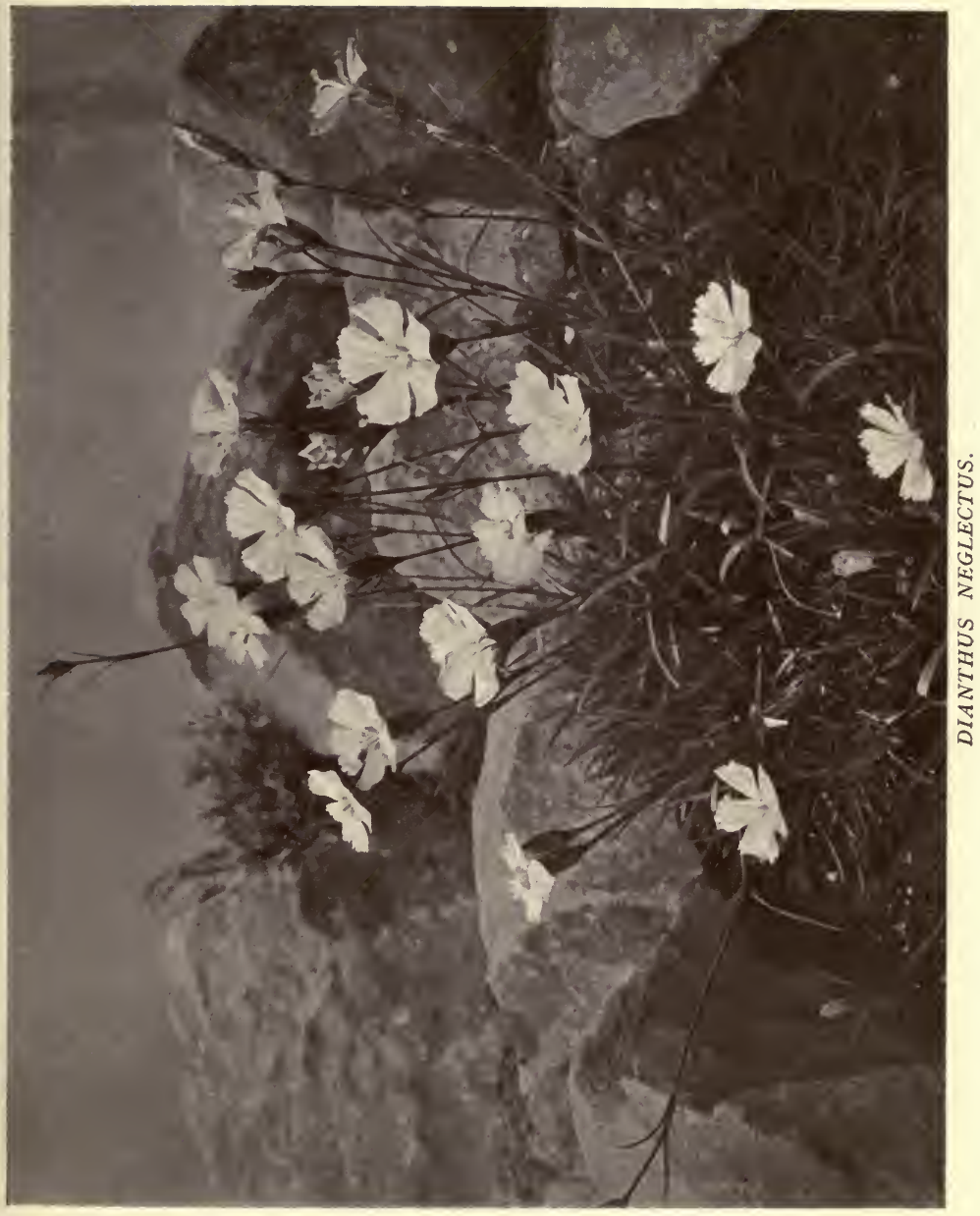




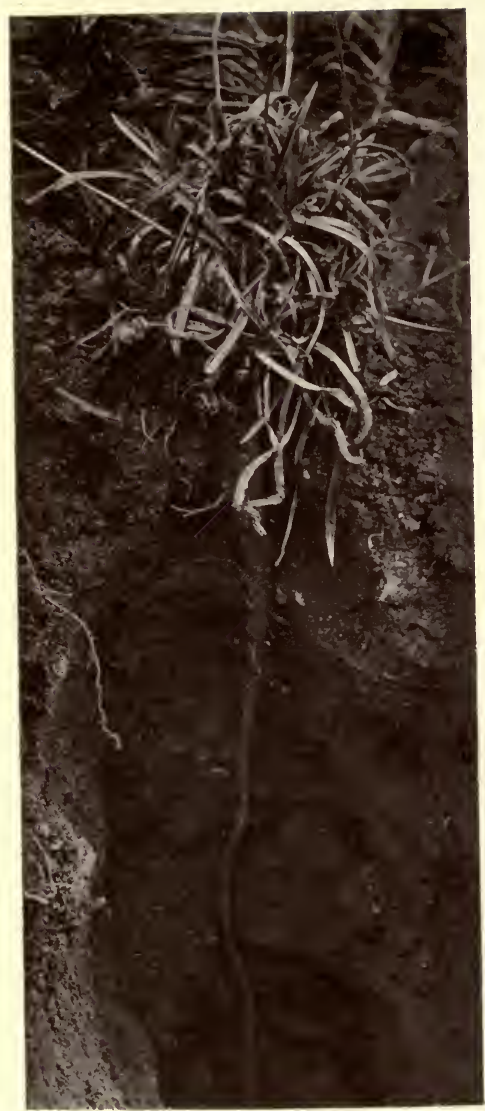

ARMERIA PLANTAGINEA WITH TAP ROOTS EXPOSED.

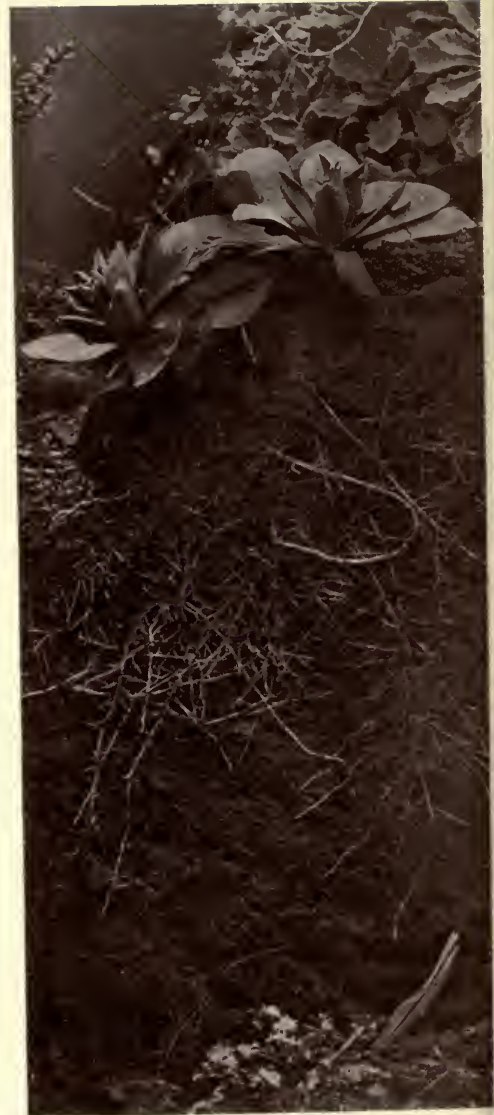

AURICULA SHOWING NATURE OF ROOTS. 


\section{CHAPTER IV}

\section{PLANTING THE GARDEN}

HAVING related, in a brief way, the manner of building my little garden, it may be of interest to make some reference to the method of planting it. As the points I shall here mention will be the outcome of my experience since the garden has been formed, it will not necessarily follow that they were the methods I adopted in my more ignorant days-but rather what $I$ have found advisable as time has gone on.

A considerable amount of the success of a garden, especially a small one, is due to the manner in which the plants are arranged therein. I hold that it should be the aim of the cultivator, where it is at all possible, to so grow each plant as to show to the best advantage its particular habit and character, and it will be readily recognised that a large number of Alpine plants have very decided characteristics. For instance, such plants as Cerastium tomentosum, and most of the Aubrietias, though easily grown in other positions, show to the greatest advantage their cushion-like habit when 


\section{THE STORY OF MY ROCK GARDEN}

young, and when older, their inclination to fall in dazzling cascades of flower, or silvery foliage, down an almost perpendicular face of rock, if planted in sucb a position-whereas, to a considerable extent, their character is lost if they are permitted to grow on the level.

Plants like Armeria plantaginea, and Acantholimon glumaceum, to take two examples only, have the power, when raised from seed, of sending enormously long tap roots, often extending three and four feet into the soil, thereby enabling them to exist in a position which, apparently, is in the Summer quite devoid of moisture, and perhaps in a mere crevice in an otherwise unbroken face of rock.

To illustrate the tap-rooting character of such plants I photographed a specimen of Armeria plantaginea after digging down and exposing the thong-like root as far as I was able, and from the illustration on page 49 it will be seen in what an almost fibreless state this root descends, despite the encouragement given it by the proximity of ample soil on all sides. The picture also shows the uselessness of providing merely shallow earth-filled pockets in one's rockery.

There must be a deep root run of gritty soil for such vigorous deep rooting plants to find a home, and then they will thrive in a way unknown if only given surface soil, where they linger in a half dead state, should the 
hot sun strike them. While the tuft of Armeria in the present example was only three-and-a-half inches high, its-root descended, as there shown, for over twenty-six inches.

Such plants I use to clothe a semi-vertical face of rock, pricking out the seedlings when only one inch high and inserting them into some small fissure betwcen two large pieces of stone, but where there is an ample root run for them beyond.

If looked after, and not allowed to dry up, until they get a hold of their new surroundings, they make, in the course of a year or two, splendid green tufts of foliage, protruding from the otherwise bare rock, and in their season are a mass of flower!

Points in the garden where the stone is perhaps less happy in appearance can be beautifully draped with such plants as Thymus lanuginosus, Cotoneaster humifusa and adpressa, the silvery cushion of many of the varieties of Dianthus, if in a sunny position, or with Dryas octopetala if in slight shade-on the other hand covering plants for quite shady places, are easily found in the mossy Saxifrages, Polygonum vaccinifolium, and dwarf ivies like Hedera conglomerata.

Irregular surfaces with ample stone cropping out, in full sun, make ideal spots for saxifrages of the incrusted section, where their silvery rosettes can bejewel the rocky ground, and from which, in their 


\section{THE STORY OF MY ROCK GARDEN}

season, can rise the graceful arching plumes of their inflorescence.

If a stone one is desirous of partially veiling springs direct from the path, and so gives little opportunity of clothing it from below, it can be charmingly draped, provided it is tolerably moist, by the employment of our little friend Arenaria balearica, which has the great advantage of taking up no room from the pathway, such as would be done by some overhanging tufty plant. If a tiny piece of the Arenaria is planted at the base of the stone in question, it will usually spread upwaids in a delightful way. Another wee plant for such a position is that miniature mint Mentha Requienii, though this sometimes suffers in our winter-probably due to its being a native of Corsica and so not quite so hardy as plants from colder regions.

By the pool side, in the peat bog, look extremely well groups of the lovely Primula rosea and $P$. denticulata. This latter is a splendid early flowering plant, and it is extraordinary that it is not more seen, since it is of the easiest culture. The first illustration on page 33 shows a plant of this Himalayan Primula just flowering after having been planted some six or eight months, while the second photograph illustrates what the same plant had grown into by the following spring, nothing having been done to it meanwhile. When it is remembered that such lovely plants may be had in flower in March 
without the slightest protection or coddling, it is astonishing that they are not more grown. The flowers as will be observed, are in the form of dense spheres, upheld on stout stalks, and vary in colour from white to deep mauve. It is, I find, advisable to break up the clump immediately after flowering, when it has attained this size, as it will have exhausted the soil about it, while the extra pieces enable us to make other and perhaps new plantations.

As a background to such plants, by the water-side, Iris can be employed, such as the clematis-flowered Iris of Japan-Iris Kampferi; I. lavigata, I. aurea. Also some of the many varieties of Spirea japonica, correctly called Astilbe japonica, such as Peach Blossom, Queen Alexandra, and the type.

I also find that Sax. peltata planted in this position gives an excellent appearance in my small garden, suggesting the lines of the giant Gunnera scabra, and it is of considerable interest in its curious method of flowering, when in spring it throws up a reddish, hairy stem some three feet high, surmounted by a panicle of white flowers, often composed of from four to seven petals, instead of the orthodox five of the Saxifrage. The leaves do not appear at all until the flower is well out, and then rapidly expand to about twelve to fourteen inches in diameter.

In the crevices of the shady parts of the pool side I 
54 THE STORY OF MY ROCK GARDEN

employ several sorts of ferns, which give a pleasing freshness in early summer time, while in one place, where its roots can penetrate to the water level, I have a plant or so of the Royal Irish Fern, Osmunda regalis. The rich golden cinnamon colour of the ripe fronds in late autumn alone justify its inclusion in my tiny garden.

On one of the bog terraces spoken of before, I use my only giant plant, Senecio clivorum, and at its base Trollius asiaticus, the orange globe flower-the appearance of these is indicated by the illustration on page 25 .

In the upper part of the garden, though where amply moist, I grow between pieces of stone and in small colonies, Primula viscosa, in addition to those in the moraine, and very pretty they look, displaying their bright trusses of flower. Primula hirsuta is a member of the same family which enjoys similar treatment.

In various positions, from full sun to shade, I also grow $P$. Auricula, not in the more or less level beds, but as a crevice plant, much as we find the Alpine Auricula in the mountains, wedged in between pieces of stone, the beautiful shell-like form of the foliage, issuing from such a place, has quite a decorative appearance all the year, while when in flower the plants are charming with their large trusses of magnificent flowers. I especially favour the pure yellow colours and am particularly fond of the varieties Celtic King and 
Alexandra, both of which increase very freely. As the Auricula is usually considered a moisture loving plant, it may seem to my readers rather unwise to grow it in an arid chink in full sun, where the surrounding stones become in summer unbearably hot. The explanation is to be found, however, by reference to the photograph on page 49 which I made one time, when rebuilding a portion of the Rock Garden.

In a crevice at the junction of two large stones, I had a plant or two of $P$. Auricula v. Alexandra, and upon moving one of the stones it disclosed the root system as there shown. It will be noticed to what a depth the roots have extended, in proportion to the size of the plant, while to a considerable degree, as will be observed they are at that part of the soil immediately in contact with the lump of stone-rather than in the soil itself, suggesting that the conditions there were more uniform, doubtless due to the moisture retained in the stone which, while never permitting the earth to be sodden, would prevent the too rapid evaporation of moisture, and so provide the conditions necessary for this and many other alpine plants.

On hot dry knolls, the Sun-roses or Helianthemums are particularly happy, and a perfect blaze of colour in their season, while in similar positions, but near the eye, Houseleeks or Sempervivums in an endless number of varieties find an ideal home. Semp. 
arachnoideum, and its larger form Laggeri (see page 24) are especial favourites with me, the silky " cob web" which covers them, especially the newer growth, is very attractive in summer, when contrasted with their intensely bright red flowers. The reason for this curious protection puzzled me for a long while, but the explanation generally accepted is, I believe, that it moderates the intense heat of the sun as it pours down on the mountain sides in Switzerland, where this little plant grows in very exposed places, and protects the soft tissue of the infant leaves, which otherwise might be damaged.

There is another large class of plants which can be used with very considerable effect in the Alpine garden, and which I have hardly referred to yet-namely, plants with silvery foliage. A large amount of the beauty of an Alpine garden depends upon the judicious use of such plants. Much can be done to emphasise a promonotory or direct the eye to any desired point of the garden by the careful use of Cerastium alpinum var. lanatum, some of the white foliaged Dianthi, such as D: casius, Erodium chrysanthum, several of the Achilleas, and planted in some crevice, in poor, gritty soil, that lovely little Potentilla nitida, and its variety alba.

A particularly decorative member of this growp is Artemisia vallesiaca, illustrated opposite. On some 


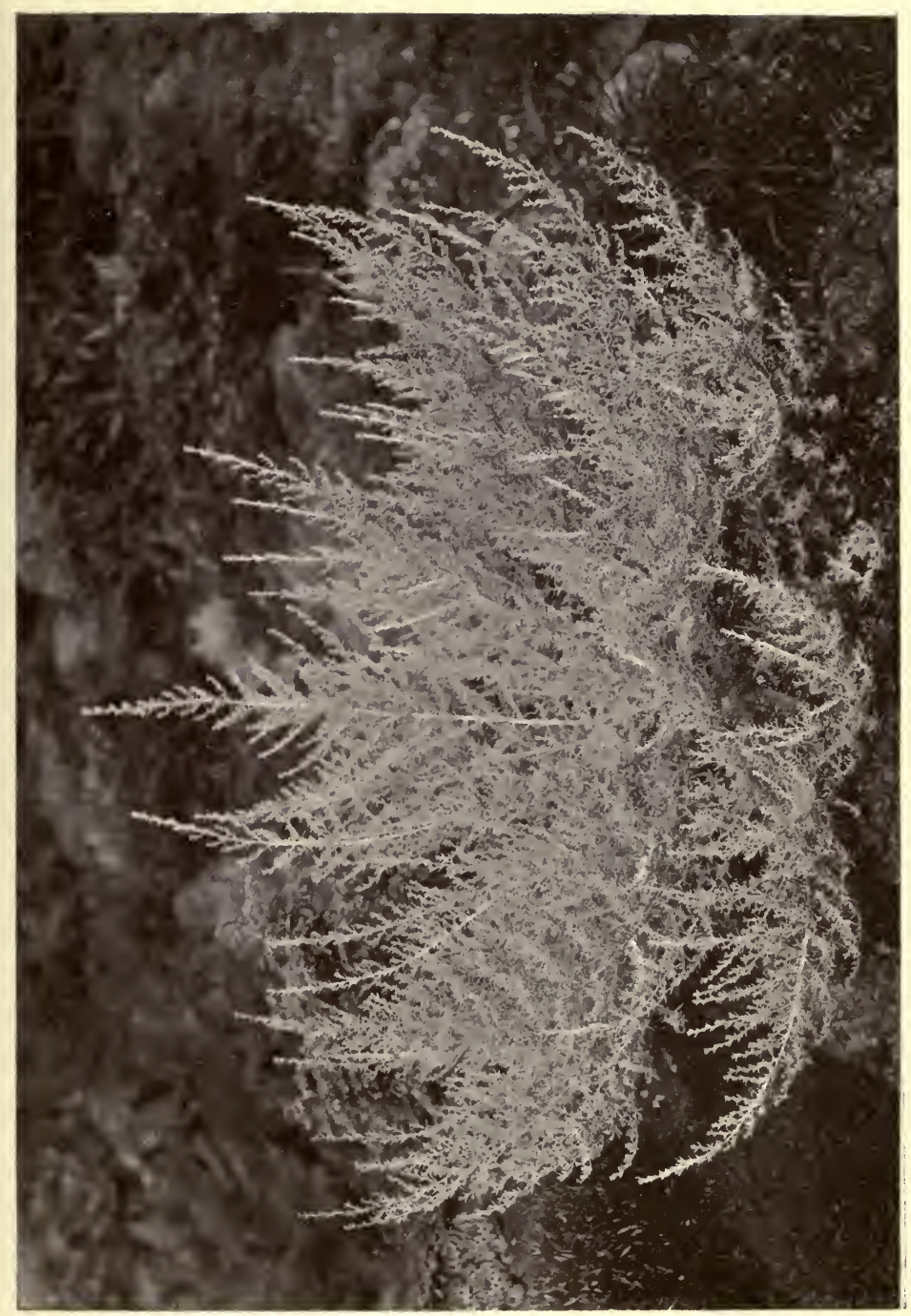


mas

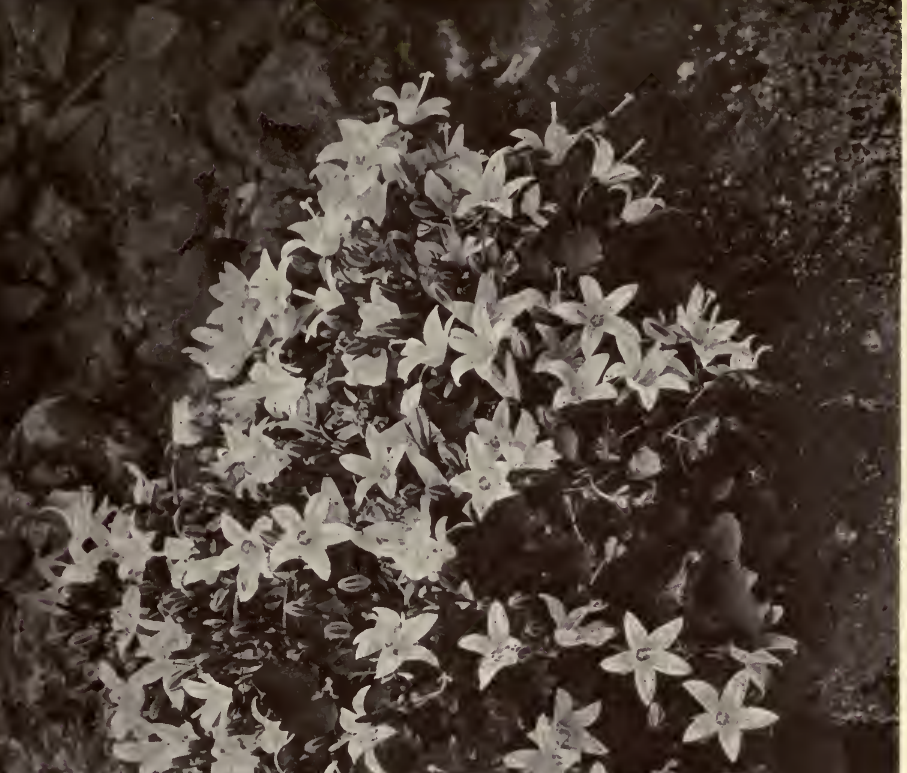


subsidiary shoulder of the Rock Garden this plant will attract attention all through the season from spring till late autumn-throwing up its graceful branches of dazzling white foliage, and as it develops, the outer ones gradually bend downwards, while new ones form in the centre, till it becomes a hemisphere some fourteen inches in diameter. It is a half-shrubby plant and dies down in the winter, breaking again from the old wood. If it can be arranged to silhouette this against a background of dark or deep green foliage, the effect is still further heightened.

Another excellent silvery foliaged subject is that tiny relative of our common groundsel, Senecio incanus v. Persoonii, only three to four ins. across the rosettesurmounted, in the summer, with pretty yellow flowers.

This plant thrives with me in a position fully exposed to the sun-and in stony soil, largely mixed with old mortar. Its chief requirement appears to be protection from overhead wet, especially in the winter, and as the old leaves die, to remove them, as otherwise they are apt to set up mildew about the plant. It is possible by the use of these and similar plants to produce a decorative effect in the garden, even when the chief flush of the flowering time has passed.

Owing to the way in which these mountain plants have adapted themselves, so as to make the utmost of a short season available to many of them, it follows 
58 THE STORY OF MY ROCK GARDEN

that the greatest blaze of colour occurs in our gardens early in the year, and unless some pains are taken to prevent it, there is liable to be a sudden collapse after about June. To remedy this, as far as may be, I have found it advisable to so distribute the early and late flowering plants, as to avoid any serious blank spaces. Naturally this treatment modifies the extreme brilliancy of any one part of the garden in May and June, but as a little colour can be easily spared at that glorious time, it is, on the whole, at least to my mind, an advantage.

The method consists roughly of planting near the earliest flowering plants, groups or specimens of rather later blooming ones, and for this purpose many of the Campanulas are extremely useful, owing to their coming into flower later than many, and also having a very long period of flower. Then again, as I have already mentioned, with certain accommodating plants, we can put them in several aspects; which again prolongs the flowering-time. Such plants as the following are very helpful in extending our season, since their normal time of blossoming is summer and autumn:-Onosma, Acantholimon, Veronica, Polygonum, Lithospermum, Aquilegia alpina, Enothera, Oxalis, Saxifraga Fortunei, Symphyandra, Violas, Spiræa, Campanulas, Primula Poissoni, and $P$. capitata. Before these plants are over, the tale is 
taken up by many autumn-flowering bulbs, including Cyclamen, Colchicums, and Crocus in several varieties.

I would especially mention the great charm that Cyclamen neapolitanum v. album, illustrated on page 97, gives to the garden in September and October, raising its numerous heads of pure white flowers from the ground before the leaves are visible, which latter, when they appear, are of a beautiful green, marbled with white. One very interesting feature of the Cyclamen is the curious habit it has of coiling up its seed stems into a spiral, in such a way as to bring the seed capsule down to the earth, and very often into it. This, I think, illustrates in a remarkable degree the care taken by some plants to protect their seeds, when, by flowering late, they are exposed to the inclement part of the year.

Of the many Colchicums, perhaps $C$. speciosum (see illustration on page II2) is the most imposing - throwing up its glorious cup-like flowers six to twelve inches high, from a carpet of some dwarf growing plant, like the smaller mossy saxifrages, or Arenaria.

One has to grow these beautiful autumn-flowering gems to thoroughly appreciate how welcome they are, coming at such a late time of the year.

While on the subject of bulbs, I may say that there are quite a large number of dwarf growing bulbous plants, whose native place is the Alps, which make 
themselves thoroughly " at home" here in my little garden, and most welcome they are, since the majority of them come into flower very early in the year, and few require any special treatment other than the gritty soil and good drainage, which is sure to be found in an Alpine garden, such as I have described.

Many of these plants have inconspicuous grass-like foliage, which soon dries up and disappears, and is not to any extent unsightly, when later in the season surrounding plants are in their hey-day. My practice is to plant many of them about clumps of Aubrietia, some of the dwarf sedums and mossy Saxifrages, and very charming they look rising from such a carpet-which not only acts as a foil to them in colour, but also prevents the soil from being splashed on to them by heavy rain.

Both bulbs and carpeting plants appear to be perfectly happy in each other's company, and the former in most cases reproduce themselves, both by seed and division, so that after a few years, instead of a number of single flowers some little distance apart, the garden is strewn with irregular-shaped drifts of these pretty early visitors, giving a delightfully natural appearance to the whole place.

One of the earliest of these bulbous plants to flower with me (soon after Christmas) is that sweet little Narcissus Bulbocodium v. monophyllus - the white Hoop- 
petticoat Daffodil, illustrated on page 96 . Planted in almost pure sand, in a hot sunny position, but where it will be moist in the growing season, this charming daffodil is a picture, as it throws up its papery white flowers, with yellow stamens, in January. The leaves, as will be seen, are grass-like, and are hardly noticeable when the flowers are over. It is well to give this plant, a native of North Africa, a position sheltered from rough winds, and to protect the flowers from heavy rain by the use of the sheet of glass already referred to.

Simultaneously with this comes the buttercup-like flowers of the Winter Aconite, or Evanthis hyemalis, each surrounded by its whorl of green leaves, while everywhere croci are by this time showing their green points, shortly to break into blossom.

Some of the other bulbous plants which thrive here are Bulbocodium vernum, Chionodoxa Lucilice and, sardensis, Scilla bifolia and sibirica, with their white forms, Muscari, various Narcissus, Iris reticulata, Galanthus Ikarice, nivalis, Elwesii, Ornithogalums, and English and Spanish Iris. These latter are most decorative, with their beautiful varied coloured flowers poised like dainty butterflies upon the slender stalks.

When these bulbs are not planted below some dwarf carpeting plant, I invariably sow about the place where they have been inserted seeds of such annuals as the Ionopsidium acaule, and Linaria alpina, so as to 
prevent any suggestion of a bare place when the bulbs are over.

The Ionopsidium has the interesting capacity of flowering in spring-ripening its seed, which sows itself and which is again in flower by the end of the summer ; while I have had the third generation in blossom at Christmas.

The Linaria in favoured places, such as an old wall, or the moraine, is often a perennial, but it is somewhat uncertain with me in this respect, and is best treated as an annual. 


\section{CHAPTER V \\ PROPAGATING}

HaviNG roughly outlined the method of building and planting my garden, it may perhaps be of interest if I describe some of the various methods of propagating these little mountain plants ; since a very great amount of interest is derivable from that portion of the work alone.

When quite a novice, I made several attempts at increasing my stock, with promising results, and from time to time I have gathered what information I could, thanks to the ready helpfulness of brother gardeners, until I now have little or no difficulty in propagating the majority of the Alpine plants I grow, either by cuttings, division of root, layers, or seed.

From the amateur's point of view, the ease with which one's stock may be multiplied is a strong point in favour of this form of gardening, since it enables him to readily increase the size and number of the patches of his plants, and to form a collection of his treasures in small pots, which are readily exchanged with other 


\section{THE STORY OF MY ROCK GARDEN}

growers. Even in my early days I found it extremely simple to take away the offsets from many of the encrusted Saxifrages, and Sempervivums, and pot them up in light, gritty soil, where, if kept moist and away from the hot sun, they would, in a short time, root. With the Sedums too, in most cases, one only has to break up a tuft into individual pieces, and dibble each into the soil, and keep them moist, and in a week or so they will be making roots on their own account.

In the case of most of the mossy Saxifrages it will be found that a large number of adventitious roots are thrown out along the stem-owing, I believe to the moisture entangled between the growths that form the patch, and these pieces only need planting deeply (so that about one inch of the green tip is visible above the soil) and they readily grow, provided they are not allowed to get dry for a fortnight or three weeks.

September I find a suitable month for this. When taking Sempervivum offsets from their parent clump it is advisable to secure as much as possible of the strong cord which attaches the baby to the parent and when laying the small rosette upon suitable soil, to so place a piece of stone upon this cord as to prevent the rosette from being shifted. This greatly facilitates new roots being sent out at the junction of the cord with the base of the rosette. Similarly, in the case of Stonecropswith many of them such as spathulifolium, all that is 



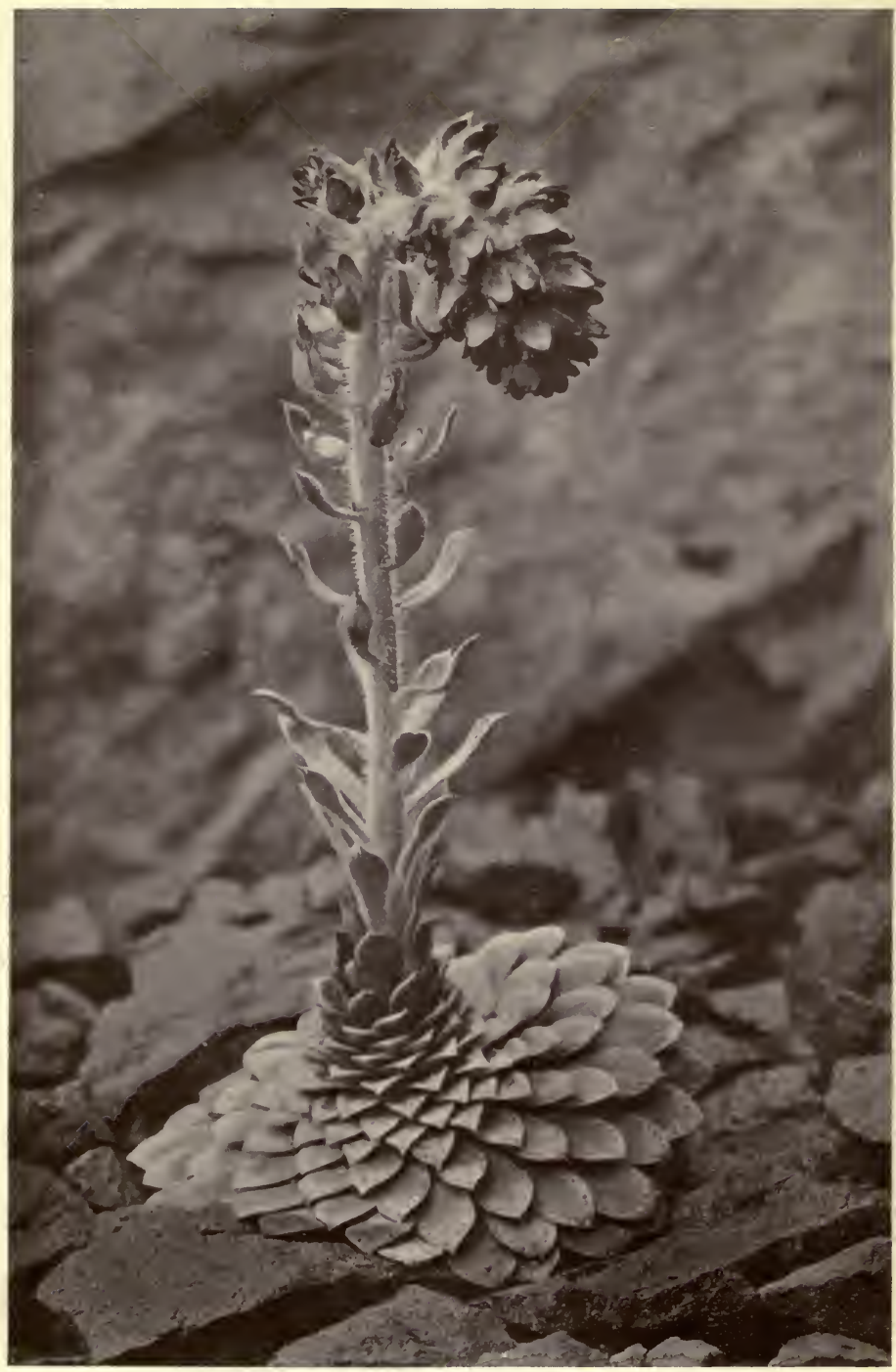

SAXIFRAGA GRIESEBACHII. 
necessary is to break off small growths, and lay them upon moist sandy soil, with a piece of stone over their lower end to prevent them being moved, and in a surprisingly short time they will root freely.

In such cases as Sedum Sieboldii, S. turkestanicum, S. spectabile, S. Telephium, I have found it best to break off in Spring pieces of the root stock, with the new growths attached to them, and these readily strike if kept moist.

At first, I used to place these cuttings, if we can apply that name to them, in the open garden in the position I had decided the new or enlarged patch should occupy, but from experience I found it much better, except in the cases of the most vigorous plantswhich by the way one seldom wishes to propagate, to put these offsets or cuttings into pots of suitable soil, and keep them in a place shielded from direct sun and yet in a good light. In one spare part of my garden I have arranged a bed of ash some eight inches deep-and into this I plunge to the rims such pots, where they can be carefully tended and looked after to a much greater extent than if scattered about the open garden, where I should have to shade them with pieces of paper when the sun was bright, and so ona most unsatisfactory arrangement, when it can be so éasily avoided.

With such plants as Primulas, like $P$. denticulata, 
P. rosea, $P$. Auricula, and of course the common primrose and polyanthus, I take up the whole clump directly after flowering - unless I require the seed-and split it up. It is surprising how easily each crown and its roots can be separated from its neighbours, without damaging them at all. These pieces if carefully re-planted, either into pots or the moist soil of their ordinary bed, will make up good plants by the following year. If they are put into pots they can be planted out at any subsequent time, after say a month or six weeks, when care should be taken not to disturb them at all, but to merely drop them into a hole which has previously been made for them of about the right size.

I also treat such plants as the Veronicas and Campanulas in the same way ( $\mathrm{I}$ am, of course, not referring to the shrubby New Zealand Veronicas), and in those two instances it is quite easy in most cases to chop. off pieces of the root-stock with the trowel, thus rendering it unnecessary to take up the whole clump.

In the case of the Campanulas like carpatica, pusilla, and muralis, if broken up in Spring, when they are just starting into growth, every little shred will grow, if carefully dibbled in.

In some cases, such for instance as Cotoneaster, Alpine Phloxes, Acantholimon glumaceum, I find it best to increase by layers. This I do by selecting 
growths which are in suitable positions, and burying a few inches of them where they can be bent down so as to touch the soil, and upon this buried piece, place a stone, which both holds the growth in position, and prevents the fine light soil I have put round it from drying up too readily. In the case of the Acantholimon it is advisable to cut the branch half way through at the point where it is to be buried. After some time, varying from a few weeks in the case of the Alpine Phloxes, to eight to ten months with the Acantholimon, it will be found that the branch has thrown out roots into the fine light soil about it, and it can then be severed from the parent and planted in its final position.

A third method of propagating, usually adopted where the two former plans are less easily employed, is that of cuttings. By this term I mean a piece of the plant definitely cut off, which would not have rooted had it been left alone, and consequently different from the case of the offsets of the rosetted Saxifrages and Sempervivums, which normally reproduce in that way. This plan I generally adopt with the smaller and rarer Saxifrages, like S. burseriana, apiculata, Elizabethe, and consists of cutting out some of the small growths, taking off with a very sharp knife the lower leaves from each piece and then inserting them into a pot, containing suitable light gritty soil, which can be plunged into ash in a close frame, that is a box with a 
glass lid which can be opened or closed at will. These tiny Saxifrages need handling with extreme care and a very sharp knife is essential, so as to make quite a clean cut without bruising.

If the cuttings are syringed daily with a very fine spray, and the glass carefully wiped to remove the moisture which condenses on the inside of it, a good proportion of these cuttings will root, and as soon as I see they are growing I give more air and gradually harden them off.

It is important to plant these little pieces very firmly, and the way I go about it is as follows:-I take a pot five inches in diameter at the top, and fill to onethird of its depth with broken crocks, then spread over this a layer of moss to prevent the soil clogging the drainage. Having previously mixed my soil according to the known requirements of the particular plant, I nearly fill the pot with it, pressing it down very firmly indeed.

The soil should be in that mellow state which allows of very firm packing, and when smoothed over by a circular piece of wood on a handle, somewhat like a household green presser, or the bottom of another pot, I sprinkle over it a thin layer of fine dry silver sand.

Then with a dibble of a size suited to the cutting I make a hole in the soil, just where it touches the side of the pot, and put in cutting number one, with the dibble I then press the soil up to it very firmly, having made quite sure that the cutting went to the very 


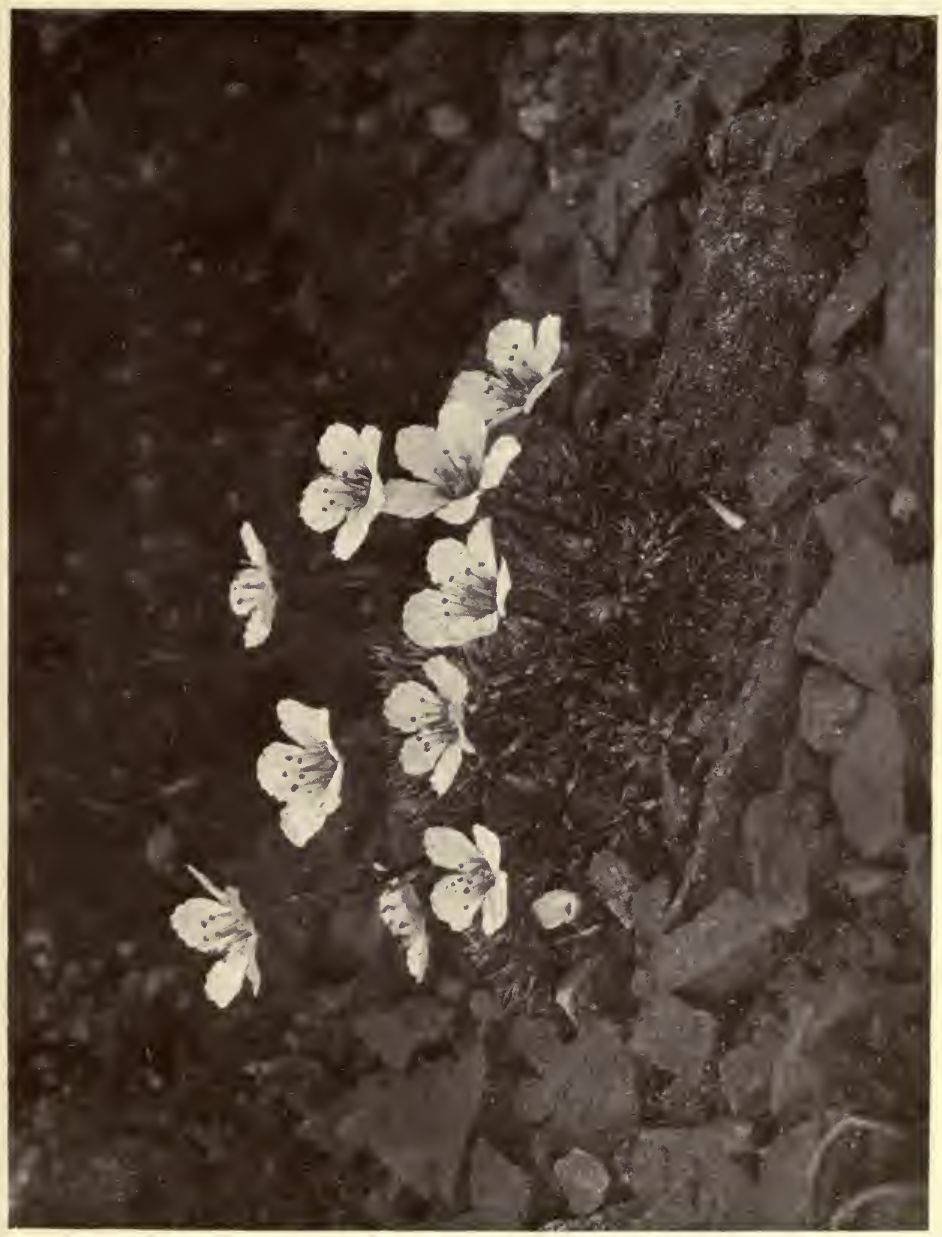




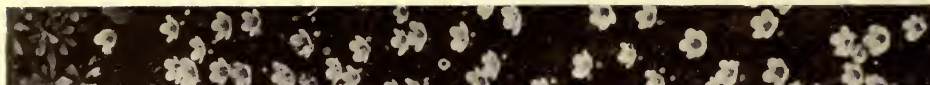
(1. +

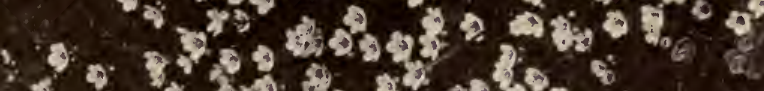

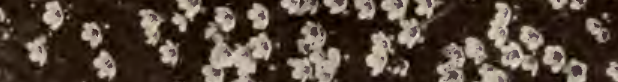

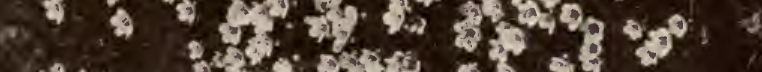

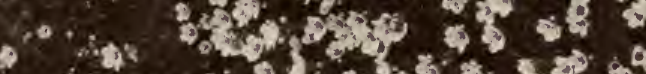

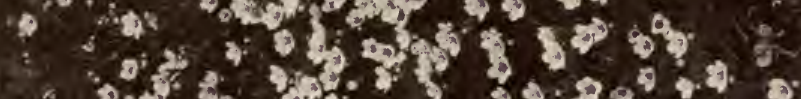

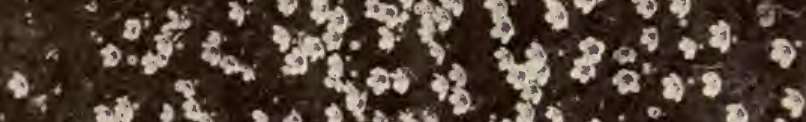

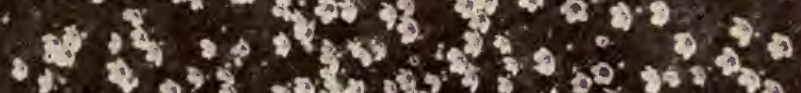

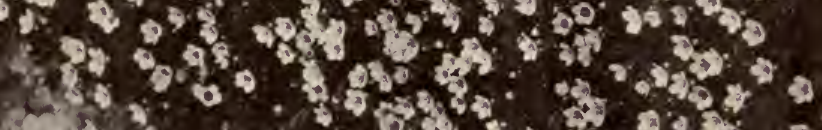

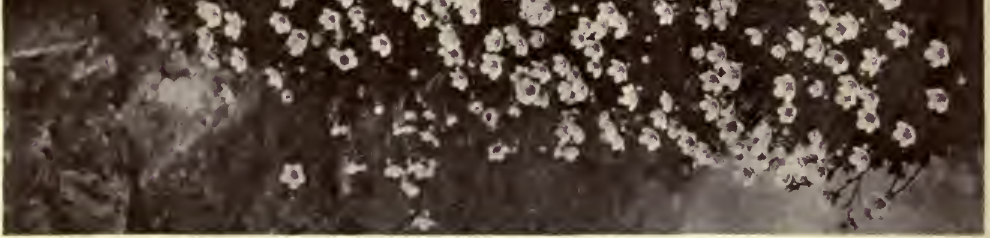

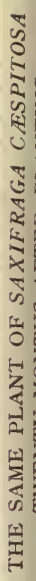

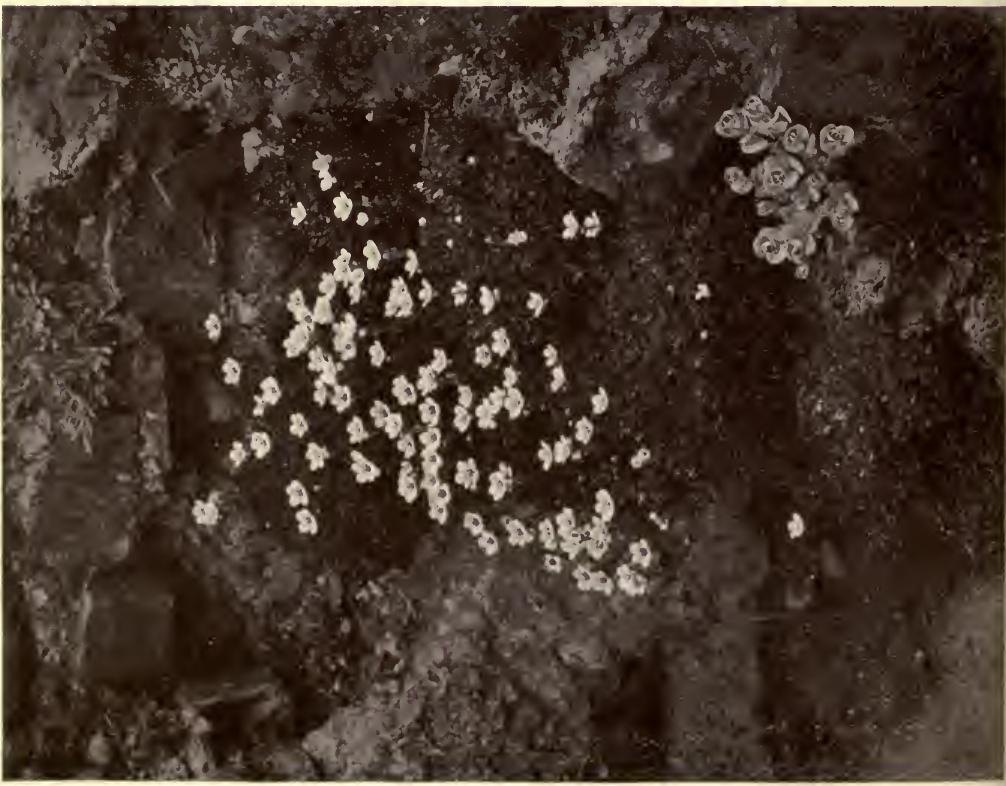


bottom of the hole. It is fatal if the tiny growth should be suspended, as it were, by its neck, owing to the hole having been made too deep. As the holes are made all round the edge of the pot, the dry silver sand falls into them to some extent, and seems to benefit the cuttings, inducing them to root quicker than if it were not employed.

When all the cuttings are inserted, say half-aninch apart, and all round the edge, which position is selected because the roots appear to relish the equable conditions of moisture which prevail there, I put the label denoting the name of the subject into the middle of the pot, and stand the whole in a dish of water, so that it may be thoroughly moistened. The water rises, by capillary attraction, into the soil, and after draining awhile, it can be plunged to its rim in the ash of the close frame.

I use this method for such other plants as the following, Cistus, Pentstemon, Lithospermum, dwarf conifers, Arabis and Aubrietias. In each of the above cases I use the current year's growth, when about two inches long.

The last way of propagating, and one which appears to me to be the most satisfactory, though perhaps less rapid, is raising the plants from seed. It will be readily understood that in the foregoing cases we are continuing the plant from the same source, merely taking a piece of it away and inducing it to form new roots. In the case of plants raised from seed, however, a marked 
feature of them is the vigour which they show, probably due to the interchange of pollen from one plant to another, thereby introducing new blood, and the increased vitality which usually follows it.

The chief drawback to this form of propagating is the liability of seeds not turning out true, due either to their being incorrectly labelled or to the crossing of various species one with another. This is especially likely to occur with the encrusted Saxifrages, Dianthus and Aquilegias. However, one can reduce the risk to a minimum by purchasing seed from reliable firms, and I really think that the little uncertainty attached to this method makes it all the more enjoyable, because the cultivator is never quite sure what he will get.

I have found that one of the chief difficulties in raising from seed is that when we can give only our spare time to our hobby, the pots are liable to get too dry occasionally, and in addition to this, the mere fact of watering them overhead, however fine the rose of the watering can, is likely to disturb the seeds, especially in the case of very small ones, such as many of the Alpine plants produce. How to obviate this difficulty was the problem I set myself to solve, and the following description of the plan I have adopted for the past two years with very great success, may be helpful to others whu are interested in this branch of gardening. I prepare the soil, and place it in the clean pots very 
much as for the cuttings I have alluded to, being careful to employ the moss to keep the drainage open and to have at least one third of the pot full of crocks. When the soil is nice and level, I sprinkle the seed on to it, from a piece of paper, which I crease down the centre, thus forming a sort of gutter or scoop. Great care is taken to sow thinly and evenly, and this is best accomplished in some place protected from the wind. I then lightly sprinkle about one-sixteenth of an inch of fine dry silver sand on the top of the pot, increasing the depth for the larger seeds, the aim being to entirely cover them and no more.

I prepare my wooden labels before hand, noting on them the place of origin of the seed, its name, and date of sowing, and this I firmly place against one edge of the pot, before the seed is spread upon it. When the pots are so far finished, I transfer them to a seed frame I specially made for them as follows:-The frame is three feet six inches by four feet six inches and fifteen to eighteen inches deep. I bricked up the sides and made it quite watertight with cement, the floor sloping towards the front.

Half-an-inch from the bottom of the frame and at the front, supported by pieces of tile, to keep it clear from the bottom, I placed a lead pipe, perforated along its whole length, with one-sixteenth of an inch holes, at intervals of one inch. These holes were pointed down- 


\section{2 \\ THE STORY OF MY ROCK GARDEN}

wards, and one end of the pipe passed through the wall of the frame, which was made watertight about itthe other end being closed up.

Into this frame I then put pieces of brick, broken to one inch cubes, to the depth of four inches, and on this a layer two inches thick of the same material but of half-an-inch cubes. When this was levelled over I arranged a second piece of lead pipe along the back of the frame and lying on this rubble-bent it up when it reached the side-and passed it through the wall, and connected it to the bottom of a small barrel standing just above the level of the frame. This pipe was also perforated at intervals of one inch where it lay on the rubble, and the openings downwards. I then spread over the whole a layer of the coarser parts of peat moss, to prevent small particles from sifting down between the rubble, and upon this I put to the depth of seven inches, fine peat.

It will be seen from the foregoing, that if the seed pots are plunged to their rims in this fine peat, and the little barrel filled with water, the latter will run out of the perforated pipe and soak the rubble, and pass off, through the perforated outlet pipe at the front.

During its passage through the frame, capillary attraction will cause the peat to absorb water and impart it to the pots and their contents, thereby keeping them always at an even state of moisture- 


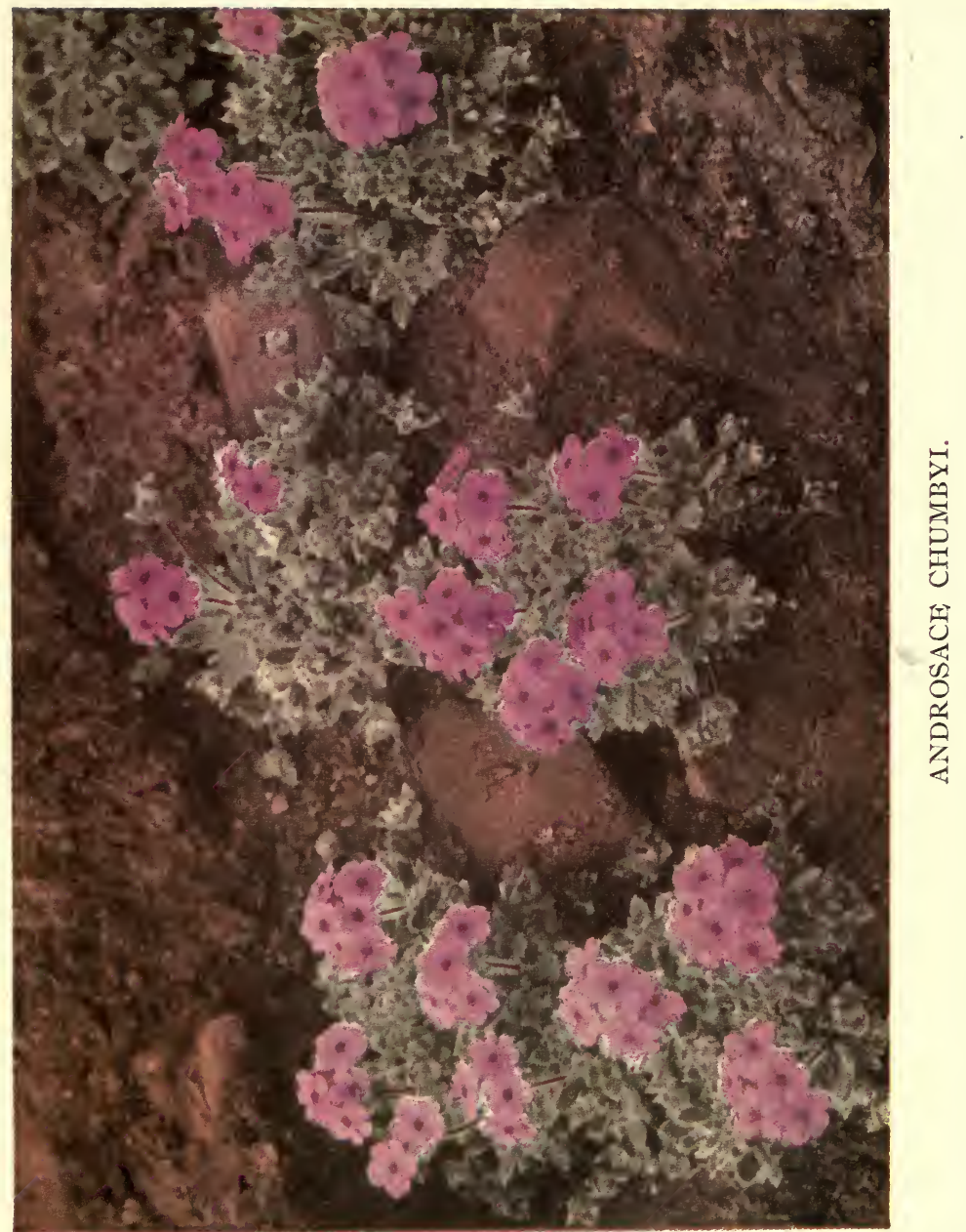



never too wet, and yet never dry. All the attention required is to daily fill up the keg with water, so that a stream of fresh liquid takes the place of that which flowed through the frame the day before.

The reason for both introducing and collecting the water by perforated pipes, instead of one larger inlet and outlet, is to prevent the water from flowing, as it readily would, in one small channel, thus coming in contact chiefly with one part of the rubble, instead of being evenly distributed over the whole area.

It is a convenience to connect a short length of rubber hose to the outlet pipe, where it projects through the wall, and this can be raised or depressed, so as to cause more or less water to remain in the frame, should very hot dry weather demand it.

The glass light I keep on the frame each night and whenever heavy rain is likely, but so raised above the sides on which it runs that a current of air is continually passing over the pots. This is very easily arranged for by making the sides of the frame three inches higher than the front and back sills, thereby forming an air space three inches by three feet six inches-or whatever the width of the frame may be-both at the back and front.

When the "light" is off, I replace it with a wooden frame covered with wire netting so as to keep the birds from investigating the luscious points of the seeds, just 


\section{THE STORY OF MY ROCK GARDEN}

as they are coming through the ground. Painful experience taught me that these feathered visitors had remarkably keen sight, and could detect the first sign of germination some time in advance of myself, much to the disadvantage of the little plants over which I had taken so much trouble. Other frames, so ventilated, I find are ideal for keeping my reserve plants in during the winter, merely protecting them from undue overhead wet.

It should be borne in mind that in many cases the seed of Alpine plants is a long while germinating, especially if the seed is not quite fresh, and on no account should a pot of seed be given up as hopeless for at least eighteen months or two years. Only last year, on January 2nd, I9II, I sowed a pot of seed, purchased on the Continent, of Sax. thessalica-nothing whatever "showed up" till February 27th, I9I2, when quite a nice crop of seedlings put in an appearance.

As a rule I find it best to sow the seed, which I save from my own plants, immediately it is ripe, irrespective of the time of year, and it is usual for it then to germinate promptly, whereas if I keep it for only two months, or so, it may hang fire for quite a long while.

To take a recent example, showing that this is by no means an unalterable rule however, I may mention that the plant of Sax. Griesebachii, illustrated on page 65, produced quite a nice quantity of seed. I gathered 
it when it seemed ripe, and to make quite sure of this I exposed it to dry air and sunlight for a week, and then sowed it on March 23rd, I9II. On February 25th, I9I2, the first crop of thirteen or fourteen little seedlings came through the soil. A friend to whom I gave a portion of the seed had exactly the same experience.

The chief enemies to guard against are liverwort and moss, both of which do their best to cover the soil with their growth. I find it best to pick it off with the point of a knife as soon as it is visible, and when the pots have been in the frame for some months, I resurface them with a fresh layer of silver sand.

As soon as the little seedlings are large enough to handle, I prick them off very carefully, and put them three in a pot-near the edge-in say two-and-a-half inch pots, and these are plunged into the ash bed, and kept moist and shaded for a week or ten days, when the shading can be removed.

It is said that exposure to frost and snow greatly hastens the germination of many Alpine seeds, especially Gentians, and during the frosty weather, I remove the glass light from the seed frame altogether.

Whether the frost does help them, it is difficult to say-often after the thaw a crop of seedlings appear, but whether this is due to frost action needs very careful experiment to prove beyond doubt-anyway it does them no harm, so far as I have been able to observe. 


\section{CHAPTER VI}

SPECIAL METHODS OF PLANTING; AND THE USE OF DWARF TREES

WHEN referring to the formation of parts of the Rock Garden, I mentioned that I would deal more in detail with planting such subjects as Sax. longifolia, Ramondias, etc., which require a more or less vertical position.

To take the case of my small plantation of Sax. longifolia as an example. Knowing that they were all the better for being planted on their side, and having seen in other Alpine gardens how beautiful they looked when so treated, I decided to make a suitable habitat for them, and for this purpose built a somewhat steep buttress-like promontory jutting out into-one part of the garden, the sides of which dropped abruptly to the surrounding level, and facing south. This piece of the rockery was composed of separate pieces of stone placed in such a manner that when the joints were filled in it would have the appearance of a more or less uniform face of rock in which crevices existed. I mention this point because it is almost a necessity to use plants of at least one-and-a-half to two inches 

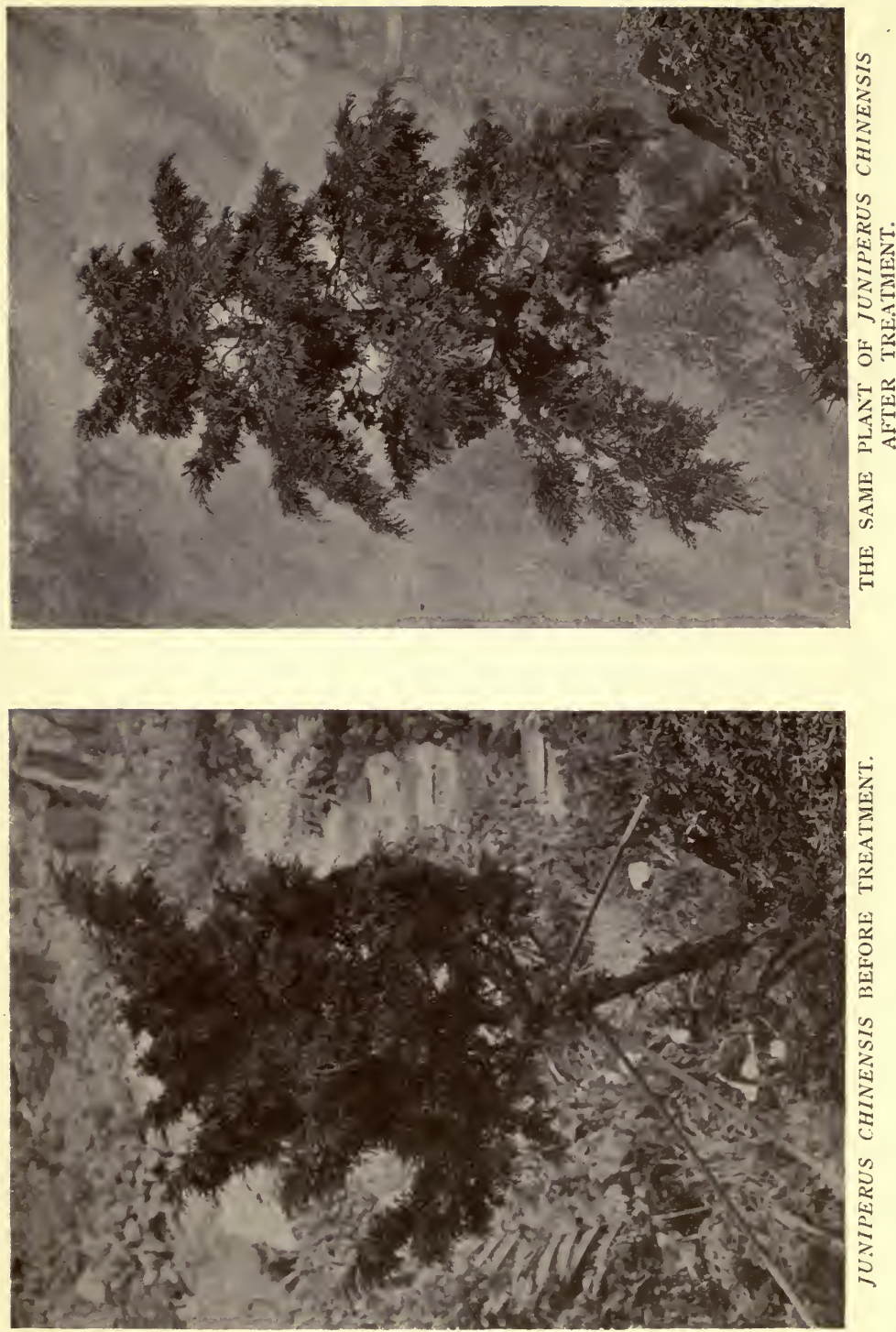


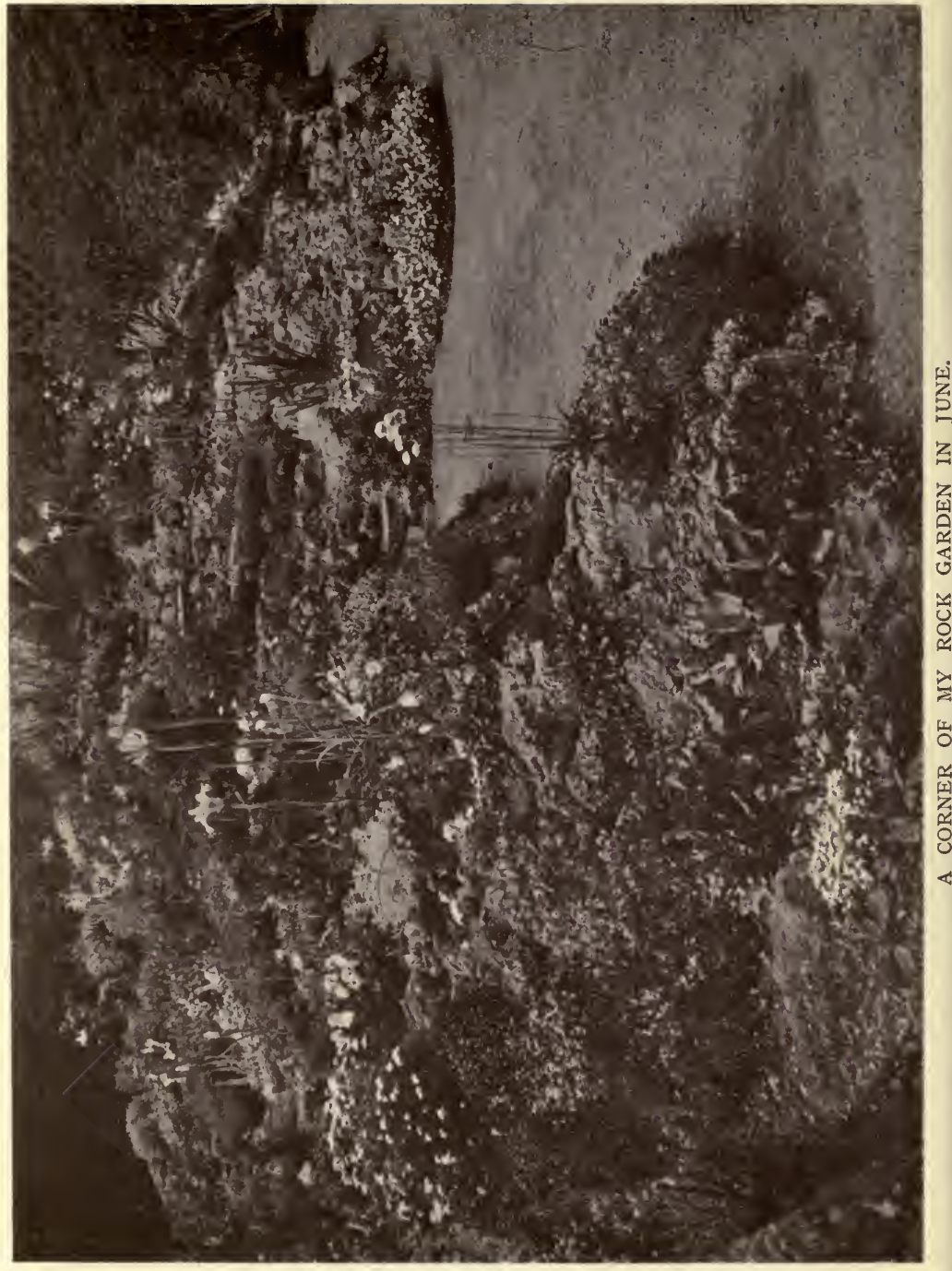


diameter and these mostly carry too large an amount of root to be "poked" through an existing hole or crevice satisfactorily.

The opportunity of obtaining small seedling plants is rare, and when one is so able-unless the ancestors of them are known, they are very liable to grow into anything but the true longifolia, since these plants hybridize so readily, that impure blood is frequently met with, and such is very apparent in this case, since longifolia when really true, unlike almost all other members of the encrusted saxifrages, never produces offsets, and reproduces itself solely from seed. It will easily be understood that under these circumstances unless the inflorescence is carefully gauzed, very unreliable progeny will usually result.

But to return to the formation of rock for the reception of these plants. It follows that if plants with a fair quantity of root are to be inserted in such a way as to protrude through a crevice, the easiest way to achieve that end is to place them in a position as the face of rock is being built. To do this, I laid the first course, of irregular stone pieces, on a well-rammed foundation, and filled in behind them with very stony soil, largely mixed with old mortar rubbish.

The saxifrages were then taken from their pots, the crocks removed, the lower roots carefully loosened, and then the plants laid each into a chink or crevice 


\section{THE STORY OF MY ROCK GARDEN}

formed, by two adjacent stones, placing the rosette in such a way that it protruded through what would otherwise have been a small opening, and with its neck close to the stone. Then by carefully selecting another piece of rock with which to start the next irregular course, and so placing it as to permit of it just bridging the small opening where the plant was lying, it was quite simple to construct the small crevice-like aperture about the plant, instead of inserting it into the already formed opening, as suggested in the case of seedling Armerias, and other deep rooting plants. By this means I was able to decorate what appeared to be a miniature cliff, with the beautiful silvery stars of this admitted Queen of the Saxifrages, the roots of which would run in a semi-horizontal direction into the limy soil behind, while owing to the upright position of the rosettes, no water would collect, or remain in their crowns.

Where it was impossible to find pieces of stone of such a shape as to exactly fit like an arch over the neck of the plant - by far the most desirable way-I made up some clay and moss into a kind of mortar, and by filling up any little spaces with this, rendered the crevices soil tight.

The object of mixing moss with the clay is to prevent it gradually creeping downwards when in a moist state from rain. This mortar is most useful for such purposes 
and it has the added quality of "giving". slightly to the growing plant.

It is advisable to carry up this spur or protruding shoulder at least nine inches above the topmost rosette, otherwise the upper ones may suffer from drought in the Summer. Some of the blood-red rosettes of Sempervivum triste formed a splendid contrast to the silver of the saxifrages when I planted them on the topmost point of this position.

The longer crevices or joints between the stone I dealt with by filling in with stone chips, like small wedges, and afterwards giving, where necessary, just a touch of cement to fix them. This emphasized the cliff-like appearance, by suggesting that the whole face was one irregular piece of rock, besides-most important of all preventing the soil from constantly weeping out at these places. It must be clearly understood that any such leakage of soil not merely dirties the rosettes, but it creates a vacant space behind the stones which is most harmful. The great aim should 'be to secure perfect solidity, with no hollow spaces behind the lumps of rock; every piece should have the earth packed as tightly as possible behind it.

I referred, in the opening chapter, to a method of toning down the crude whiteness of my concrete blocks which is so staring in the dry weather. I experimented in a number of directions, with but 
indifferent success, and then remembering that the colour of our sandstones is largely due to the infiltration of iron in solution, it occurred to me that possibly something on this line would lead to a better result. After one or two attempts, I obtained the salt, Ferri-Perchloride, and when four ounces of this is dissolved in approximately a gallon of water, and applied to the concrete lumps by the aid of a small brush or mop, the result is a rich, yellowish brown colour most acceptable in contrast to the varying greens of the foliage. I find it well to water or syringe the various pieces of "rock" a few minutes before applying the iron solution, thereby encouraging the latter to flow over it readily instead of being repelled by the dry surface. While I take care not to drop or splash the solution on to the plants, I have seen no indication that it is harmful to them.

In my Ramondia corner I followed much the same course, laying the plants in position as the building proceeded, and filling up the small crevices with clay and moss. The frontispiece to the book, from my own photograph, illustrates the handsome appearance of these invaluable plants.

Such plants as Auricula alpina, the yellow auricula of the Alps, and Sax. cochlearis v. minor, that silvery little fellow which " packs" itself with such delightful hummocks, I used, with what I consider very good 
-effect, to furnish oblique seams between the larger lumps of rock in another part of the garden.

Often when building fairly steeply, I found that the pieces of stone would so arrange themselves as to give me a crack perhaps one foot long and one to one-and-ahalf inches wide, at an angle of say forty-five degrees. This slanting fissure I dealt with in the following way. Firstly, when the stones were firmly settled down and the soil well hammered in behind them, I shaped a piece of wood, just the right size to pass freely into the crack (approximately one inch by two inches) and with this I found I could drive the soil well home through this small gap, to a much greater extent than by any other means.

For the method of planting I am about to detail the thorough packing of the soil in the first place is of great importance, since it is almost impossible to do it afterwards.

Starting from the bottom, I fitted into the crevice a splinter of stone, which would wedge tightly and 'close up the lower two or three inches; after filling in with limy soil to this point and well compacting it, I put in my first plant or small tuft of Sax. cochlearis so that its neck rested on the upper surface of the wedge of stone, with the roots well spread out almost horizontally on to the soil behind, but sloping slightly downwards. 
Next, with great care, I put a small layer of my clay and moss some quarter of an inch thick on to the neck of the plant, to prevent it being bruised, and then drove home my next wedge of stone, repeating the process and filling up with soil each time, so as to separate my plants, or tufts, by about one-and-a-half inches.

If the reader has followed this description, it will be seen that by the time I reached the end of the crevice which before had been a gaping crack, it was filled from end to end by tight cushions of the Saxifrage or the shell-like rosettes of the Primula, alternated with pieces of stone. In the case of the Saxifrage I found it greatly enhanced their beauty, if I used as the wedges pieces of the Old Red Sandstone, the lovely rich colour of it contrasting beautifully with the shimmering silvery rosettes of the Saxifrages-a very small quantity of this stone which I had was thus used economically and to its fullest advantage.

When the whole place was planted, I carefully fixed each wedge, where it seemed to require it, with a little tinted cement, to prevent it becoming loose from the action of the frost, the blade of my pocket knife making an excellent " trowel " for this delicate purpose. since great care had to be taken to avoid touching the leaves with the caustic cement. A little powdered Venetian red and gas black mixed with the cement, 
is a ready means of taking the "edge" off its crude whiteness.

In a few months after planting, given a suitable position-full sun in this case, the crevice was entirely hidden with these charming little plants, only here and there peeping forth from between them the wedge of reddish stone, the sloping position being just what these little mountaineers revel in.

From the many rock gardening books I have read I have drawn the conclusion that on no account should anything in the nature of cement be allowed in the Rock Garden, and while doubtless it would be unwise to use it to any considerable extent to hold the stones in position, I have found the intelligent employment of it in special positions, such as the foregoing, to be most useful, and as far as I can see, no ill effects have followed therefrom.

It must also be borne in mind, that while it is most necessary, in the largest Rock Garden, to prevent the leakage of soil from one part to another, this is inten- sified when the space available is as tiny as mine, and too much attention cannot be given to prevent it. Often at some leaky spot the use of a small piece of stone fixed with cement will make all the difference between success and failure, while the scale of the whole garden is too small to permit the use of a stone large enough to stop the gap. 


\section{THE STORY OF MY ROCK GARDEN}

It will be noticed that I am continually referring to old mortar and broken brick as excellent materials to mix with the soil. The former I use as a substitute for chalk or crushed limestone, to furnish such plants as require it-notably the silvery section of the Saxifrages -with lime. Usually sifted mortar, the detritus from pulling down old buildings, is easily obtained near a town, and in the absence of natural limestone or chalk, answers admirably, by not only providing the necessary lime in, apparently, an easily assimilated form, but tends to keep open the sticky soil of my localityand as everyone knows, who labours under this disadvantage, no matter how much we may lighten the heavy soil by the addition of sand, it always seems to partake, though in a modified degree, of the allpervading soapiness.

The broken brick makes an excellent substitute for sandstone in the soil, not only to keep it open, but to prevent the too rapid evaporation of moisture, and yet ensure quick drainage. I find that really well burnt but porous bricks are the best, and if for use near plants that dislike lime, care should be taken to see that no old mortar is adhering to the bricks before they are crushed. I generally use of this stuff the siftings through a half-inch sieve.

I have already dealt with the manner in which I constructed my little bog beds in Chapter II., merely 
clay lining the bottom of a depression and filling in with suitable soil. It is surprising what a host of small plants I have accommodated in these places; in the Springtime one never seems to know what charming little acquaintance may be coming through the soil next. At the earliest dawn of Spring come a few Snowdrops, followed almost immediately by some Muscari, before these are well out Primula denticulata begins to open its cauliflower-like buds, in which the flower trusses have lain so snugly packed through the Winter.

Erythroniums, or Dog's Tooth Violets too are here, and the Wood Anemone, $A$. nemorosa, and its many varieties including that beautiful pale blue form $A$. Robinsoniana, while a little later Primula rosea opens its lovely carmine flowers, coming through either a carpet of Cotula squalida, or C. accenafolia (which by the way must be well looked after, or it will swamp everything) or Arenaria balearica and A. caspitosa. Here also in full sun, though always moist, trails the ruddy branches of the sweet little twin flower Linnca borealis, and its larger form americana, which in their season bear their quaint pink flowers.

As the year advances, $P$. involucrata, from the Himalayas, gives me its white flowers flushed with lilac, and the larger counterpart of $P$. farinosa, known as $P$. frondosa. 
In quiet corners grow the dwarf leathery leaved tufts of Soldanella alpina, which in Spring are surmounted by their charming deeply fringed bells of lavender, while last, but by no means least, that glorious blue-flowered Columbine, Aquilegia alpina vera.

It is surprising too, what a number of plants flourish in this spongy medium, which one would least consider suitable residents for moist positions. I remember only two years ago finding a self-sown seedling of Sedum turkestanicum growing there, which much to my surprise, retained its habit, and even flowered last year. It makes an ideal place for germinating seeds, especially those one does not desire.

There is, not far from my bog bed, a laburnum tree, and I believe one hundred per cent. of the seeds that blow on to the moist soil germinate, necessitating constant weeding. Still even this quality has its advantages, for when one has a few houseleeks, which have fallen off from their parent clump, and are found in an almost desiccated state of dryness, by placing the right way up on the peaty soil, they throw out numerous roots in a week or so, and are then easily transplanted to a more natural habitat.

\section{DWARF TREES.}

In most nurserymen's lists of Alpine plants there is usually included a section dealing with dwarf treesprincipally conifers-suitable for use in the rock garden. 
These little trees make ideal subjects when suitably placed, though I fear they are too often inserted into the positions they occupy largely because there happens to be a vacancy in that place. It has always seemed to me that they are so valuable both from the decorative line they give, and from their evergreen character, that considerable care and thought should be given as to just where they should go.

Another point which often strikes me in this connection, is, that in most cases these little trees are planted and then left severely alone, which usually results in their making a more or less solid head, somewhat after the shape of a bee-hive. It seems to me that their employment in the rock garden should be to simulate as far as possible, on a small scale, the mature trees of the mountains.

Owing probably to their dwarf habit of growth, and the sheltered positions they generally occupy in our gardens, when they are left entirely alone, they are apt to grow dense and crowded, and so lose those characteristic lines which are noticeable in an old weather-beaten tree.

How extremely picturesque are those trees we often see in the mountains, clinging to some projecting crag and throwing out their comparatively few wind-driven branches, in the most delightful way. If we could only induce our dwarf conifers to grow somewhat after the 
same manner, how very decorative they would be, among our small Alpine plants.

Some time since I made an experiment in this direction, and a few notes with regard to this may be of interest, and I trust helpful to others who are of the same way of thinking as myself.

On a shoulder of my Rock Garden, near to the steep cliff dropping down to the pool, I originally had a small Rowan. After a time, however, this grew too large to be in keeping with my tiny garden, and I was compelled to remove it. Desiring to replace it with a dwarf or slow-growing conifer, I secured a plant of Juniperus chinensis, three feet high, and with a naked stem for the first eighteen inches. This I carefully planted in the desired spot, and staked it securely to prevent it being swayed by the wind. It then appeared as is shown in the first photograph on page 76 . It will be noticed, that though it is by no means as dense as many of the slow-growing dwarf conifers, it still has a youthful appearance, and would not suggest to anyone a mature tree of the mountains.

When the rains had settled the soil well about the roots, I proceeded to replace the three bamboo canes with pieces of thin copper wire, arranged in a triangle and fastened to the upper part of the bare stem, radiating to three points, where I securely fastened them to concealed iron pegs in the neighbouring rock. 


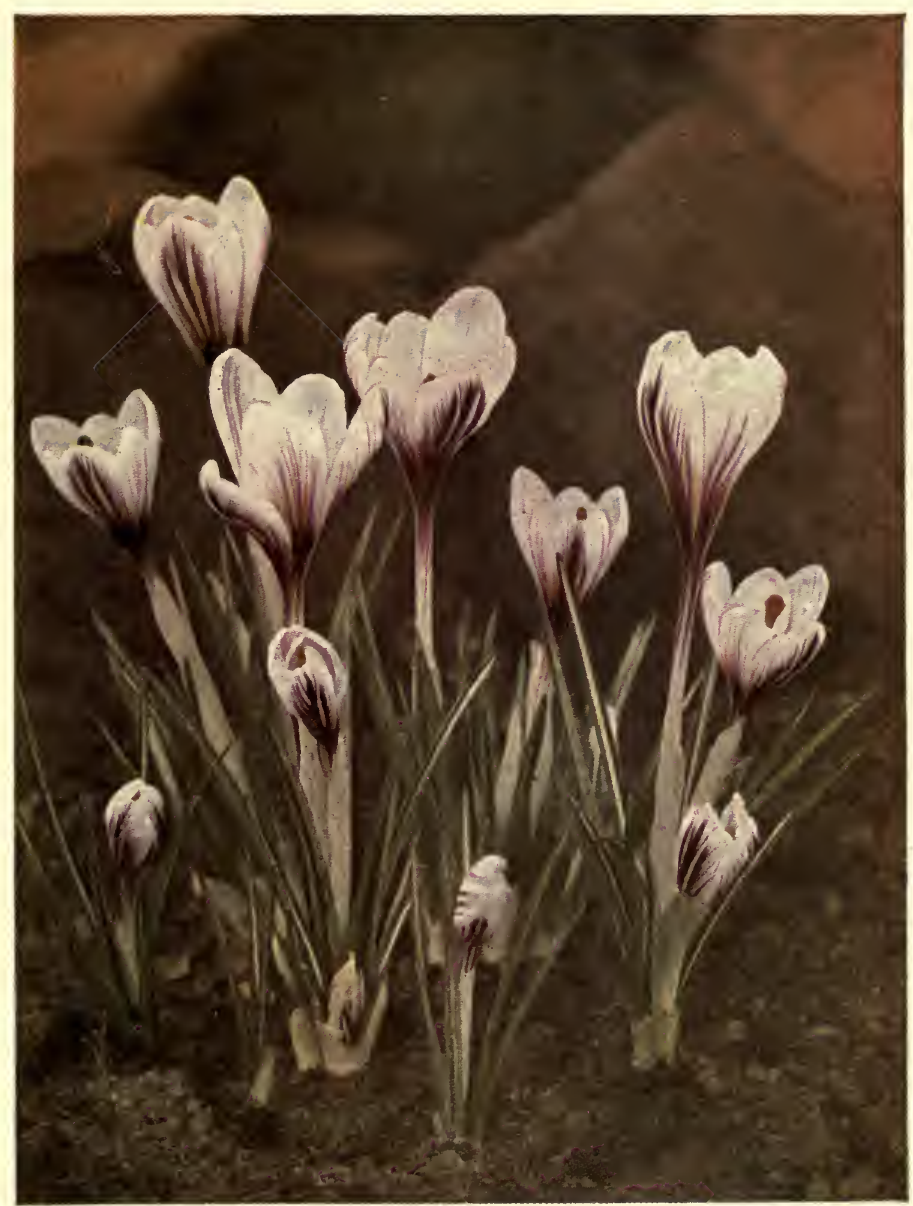

CROCUS VERSICOIOR. 

I selected the copper wire because in addition to its being strong, it tarnishes in a few days by exposure to the air, and becomes practically invisible at a few yards distance. Before fastening it round the stem, I carefully bandaged the latter with a piece of pliable leather.

I then proceeded to carefully bend down one of the lower branches, till it occupied what I considered a more suitable position, and here I fastened it, again with thin copper wire, to one of the previous supports, or to the stem itself, using a smaller bandage of leather to prevent the wire cutting into the branch.

I worked upwards from the lowest branch, dealing with each in a similar way, taking great care to induce the branch to bend at a natural angle, such as we see on large trees, due to the weight of the branches themselves-if the angle taken did not appear correct it could generally be righted by allowing the wire to grip the branch at a different place.

In a few cases I found it necessary to cut out a portion of the growth, but only to a small extent, and then only after making quite sure that it could not 'advantageously be used in one position or another.

At some points it was advisable to attach a second wire, and carry it away at right angles, so as to draw the branch sideways as well as downwards, and this I also fixed to a concealed peg. In one case, doubtless due to insufficient care, I accidentally cracked one of the 
older branches, and this I at once treated with Stockholm tar, dropping it into the wound, and binding up the whole with tarred string. So far this seems to have prevented any decay setting in, and as this occurred some time ago, I am hopeful that no ill effects will follow. When I had finished treating the subject in this way it appeared as shown in the second photograph on page 76 and to my mind better represents a mature tree than the former one, and certainly is more decorative. Where the small leather bandages were of a colour which taught the eye, I applied a small quantity of brown spirit stain, which entirely prevented them being noticeable.

After a time, probably a year or eighteen months, depending upon the age of the subject so treated, the branches will, I hope, have hardened into the required positions, and the wire stays can be removed.

I believe much may be done on the lines of the foregoing, to greatly improve many of the dense growing dwarf trees used in the Rock garden, and certainly where one's pocket is not of the deepest, much interest is derivable from manufacturing one's own miniature trees.

A close inspection of good specimens of Japanese dwarf trees is very helpful, and especially the manner in which the branches are tied, and makes one realise how extremely clever and painstaking are these Eastern people. 


\section{CHAPTER VII}

A DESCRIPTION OF MY GARDEN AND ITS INHABITANTS THE YEAR THROUGH

I wILl here endeavour, in as brief a way as possible, to give an idea of some of the little mountain plants which interest me so much-roughly as they come into flower from January onwards.

It must be understood that the time of flowering of each of the plants mentioned is largely dependent upon the kind of weather we happen to be favoured with and this is especially so during the earlier months.

Very many of the Croci, for example, show through the ground before Christmas, and if the weather is mild, as it often is, come rapidly into blossom; if on the other hand, it should continue frosty, they seem to stand quite still for weeks, until a gleam of sun and a mild day or two sees them develop in a most extraordinary manner-transforming themselvés from unopened buds in the crowns of the plants, to widespread blossoms in, so to speak, a few hours.

January is usually ushered in with a few of the yellow flowers of Crocus vitellinus, in sheltered corners 
of the garden, springing from a carpet of evergreen, such as Arenaria or Sedum, often accompanied by Eranthis hyemalis-the little Winter Aconite, with its bright yellow flowers and fresh green leaves.

Before many days are passed Narcissus Bulbocodium monophyllus, as shown on page 96, keeps them company; the delicate white flowers of this choice little daffodil look strangely fairy-like in this dead time of the year.

It is difficult at any time from December to March to find that pretty little shrub, Daphre Mezereum, without a few of its sessile pink blossoms upon the bare branches, and often during mild intervals it is quite gay.

It is not unusual, when Christmas has been preceded by a mild period, to find a few heads of rich purple flowers upon Primula capitata, while here and there, the common primrose, in odd corners, is ever ready to give us a touch of colour. Snowdrops, too, generally push up their choice flowers at this time, though but sparingly - Galanthus Elwesii usually being among the first-while upon the gritty portion of the rockery, devoted to Saxifrages, that gem of the encrusted section, S. Griesebachii, and its near ally $S$. Stribnryi are beginning to protrude their centres, and-becoming daily more and more crimson. The former of these two, especially, is delightfully attractive all through the winter, often beginning to rise in early 
October and not fading until well into March. The beautiful crosier-like form of the inflorescence and the symmetrical outline of its rosette is well illustrated on page 65. Especially gritty, limy soil is desirable for this plant, and also a protecting glass, to keep off undue wet.

Here too, from the greyish-green, hedge-hog-like cushions of foliage, Sax. burseriana is sending up its lovely white flowers of a satin-like texture, supported on crimson stalks. Charming, indeed, in mid January, is this little inhabitant of easten Europe ; the reproduction on page 68 illustrates how I prevent the soil from being splashed on to it-by surrounding it with stone chips, even though it is not planted in actual moraine soil.

In those quiet half-shady corners devoted to Cyclamens, $C$. Coum and $C$. ibericum are opening their choice flowers (C. Coum album being an especial favourite with $\mathrm{me}$ ) the effect being greatly heightened by the rich green-with red undersides-of the leaves that accompany them.

With the advent of February we are able to appreciate the slightly lengthened days, and the increased vigour of the light, both of which are active factors in the development of the blossoms, the chubby little greenish knobs with which the patches of Sax. apiculata have been for some weeks studded, rapidly elongate and 


\section{THE STORY OF MY ROCK GARDEN}

burst into flower, showing us a green hummock spangled with pale lemon-coloured blossoms!

The Hepaticas, too, quickly unfold their silky growths and throw up their lovely blue anemone-like flowers. With me the pink form is rather later-it being usually March before it opens.

Of the Croci we now have quite a show, their brilliant colourings causing them to stand out vividly against the darker coloured background-the most attractive being the golden cups of $C$. chrysanthus, the open flowers of $C$. Imperati, of a soft blue tending to purple, among its unopened buds, the outside of which are a curious creamy buff; while most lovely of all perhaps, is C. Sieberi, of the clearest lilac blue, with rich yellow stamens.

At this time come in small groups that effective little Scilla bifolia, making such a brave show, long before its relative $S$. sibirica is open, forming as it were miniature fountains of rich blue stars, while contrasted with these are the dainty pendent white bells of Leucojum vernum, somewhat like enlarged snowdrops, though even more dainty.

The flower I look for in February, however, with the keenest anticipation, is that early gem, Iris reticulata. This is an interesting member of a glorious genus. Pushing through the ground in early January a sharp pointed spear-like growth, it produces one four-sided 
leaf, not, however, quite square, and tipped with a curious nail-like point, probably to aid it piercing the half-frozen ground. When about four inches high, other growths appear, and encased in these latter is the flower. Usually the bud opens when only three or four inches from the ground, and from it emerges a charming typical Iris flower of the richest purple, and in the throat net-like veins of brilliant gold. It is about three inches in diameter, and shaped like a delicate Spanish Iris, while it is strongly perfumed as with violets. Groups of this lovely little flower can hardly fail to attract, even when the garden is already gleaming with other early and beautiful subjects.

February in my garden is essentially a month of awakening life, every part is teeming with points of new growth, while the ground is literally alive with bulbous plants pushing their way through it, soon to produce a riot of colour in every portion.

March brings me Anemone blanda, that beautiful Greek windflower, with petals of richest blue, rising from its bronzy green foliage. In many gardens I know it is much earlier, but for some reason it develops later with me-it is none the less welcome, however, on this account, and if planted not far distant from a patch of Sax. Elizabatha, its colour contrasts delightfully with the rich yellow flower, poised on crimson stalks, of this latter plant. 


\section{THE STORY OF MY ROCK GARDEN}

I learn from several growers that this Saxifrage is sometimes a shy bloomer; perhaps I am fortunate in having a form which flowers fairly freely.

In sunny places on the moraine, or in sharp gritty soil, where its roots can find a cool moist medium during the hot weather, Sax. oppositifolia is now opening its purplish crimson flowers, and the variety splendens is especially prolific with me, and at so early a time in the year the rich colour of its flowers, on the dark green carpet of trailing growths, is very acceptable. We also have at this time quite a variety of small daffodils, including that miniature form Narcissus minimus, seldom rising more than three inches from the ground, but perfect in every respect. Rather larger is $N$. Bulbocodium citrinus, the sulphur coloured hoop petticoat daffodil, and $N$. cyclamineus, with its rich colour and reflexed sepals.

One of my favourites, however, is $N$. triandrus albus, so delightfully named " angels' tears," with its pale cream flowers, rising from grass-like foliage. This little daffodil makes a splendid companion to Bulbocodium vernum, the Spring meadow saffron, contrasting well with the latter's rosy purple flowers, emerging abruptly from the soil. Both of these bulbous plants are easily accommodated, as to soil and position, and if arranged in irregular drifts are very charming when in flower ! 


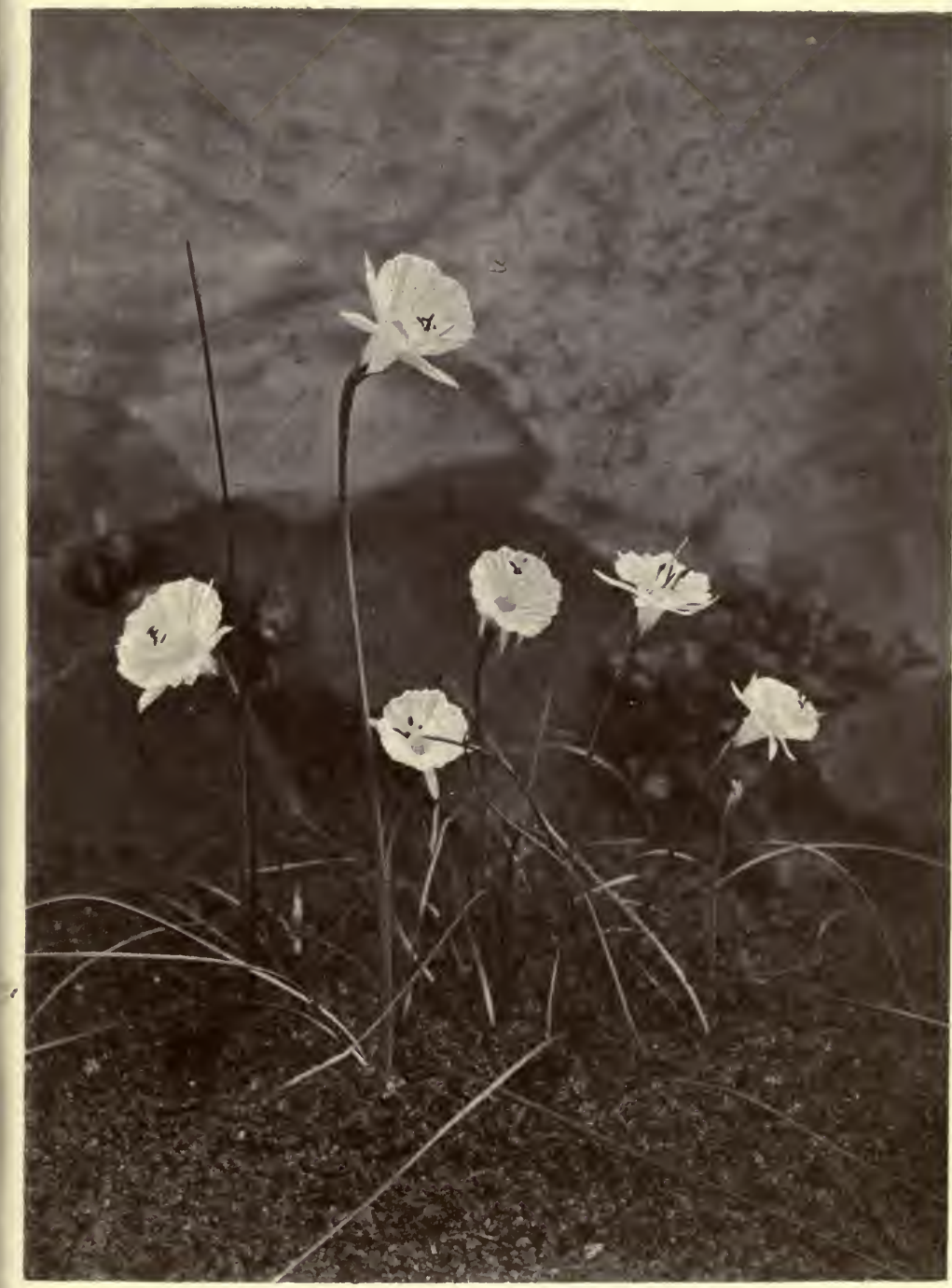

NARCISSUS BULBOCODIUM VAR. MONOPHYLLUS. 


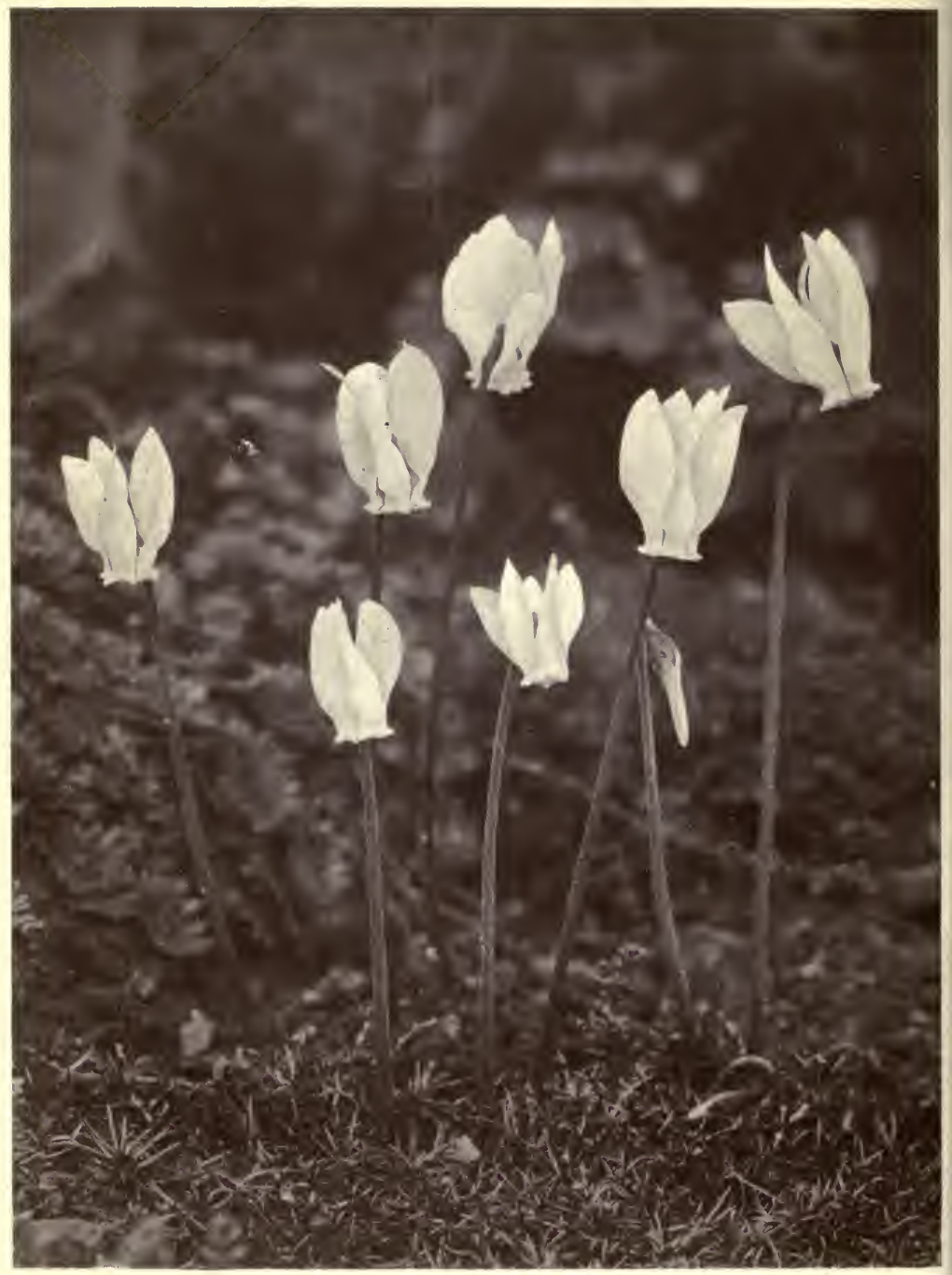

CYCLAMEN NEAPOLITANUM VAR. ALBUM. 
Now, too, is the time of Crocus versicolor, that gem of the Spring flowering group hailing from the sunny south of France. It is surprising that it should prove so good tempered in our variable weather, but if planted in sandy loam and a little leaf-mould it seems quite happy. It looks charming when the March sunshine falls upon a colony of these blooms, with their white or faintest lavender petals, veined with rich purple blue, while glistening within this beautiful protecting cup, the golden stamens gleam forth. (See page 88.)

Towards the end of the month, Caltha palustris and its much larger relative $C$. polypetala open their golden flowers down by the pool side, and though the former at least is a comparatively common plant, they are both very welcome, since bog plants as a whole are less early in their flowering than those in drier positions.

When the soft days of April arrive we are surrounded by flowers on every hand. The steeper parts of the pool-side are draped with cataracts of Arabis, tumbling down to meet the lovely Primula denticulata, in a variety of shades which adorn the edge of the poolwhile from the bog bed, rise on three foot hairy stalks the inflorescence of Sax. peltata.

Higher on the rock, in irregular streaks, strong patches of richest purple denote the presence of Viola gracilis, while not far off the shaggy nodding heads of the lovely Pasque flower, Anemone Pulsatilla, gently 


\section{THE STORY OF MY ROCK GARDEN}

sway in the soft air ; this last plant delights in a chalky soil mixed with leafy humus, while the viola appreciates a sandy compost.

Just beneath the eye, in the semi-boggy bays abutting on the path, Soldanella alpina is shaking its lavender bells to the wind, and close to it is Primula farinosa, from whose greyish green rosettes of leaves has emerged the farina-covered stalks supporting heads of rosy pink star-like flowers. The illustration on page 32 gives some idea how pretty groups of this lovely little native of Yorkshire look-it also shows, partially buried between the plants, the pieces of stone to which I have earlier referred.

In the rocky clefts, the shell-like foliage of the Auriculas is now adorned with their flowers, and irregular plantations of $A$. Celtic King are glowing patches of rich yellow.

Primula marginata too, in somewhat similar positions, is in flower-in this case pink is the prevailing colour, the stalks being very powdery, while the extreme edge of the serrated leaf is farina-covered; a very striking little plant, if near enough to be closely examined.

On the moraine, Draba aizoides has had its tufts of green foliage transformed into hummocks of bright yellow, while Draba dedeana is one mass of white flowers, and looking the picture of happiness among the stone chips. 
Of the several close-growing plants in that part of the garden devoted to the small saxifrages, Sax. Salomoni appeals to me strongly, sending up its pure white flowers two or three on a stem, from a particularly close spiny cushion of hard grey foliage-near to this is Sax. rocheliana, with small compact rosettes of leaves, and flattish heads of white flowers.

In the more shady portions, green hummocks of the mossy section, such as Saxifraga caspitosa, make the garden very gay, and to illustrate how extremely easy they are to grow, I prepared the photographs seen on page 69 ; the first shows a plant of $S$. caspitosa some eight months after planting, while the second illustrates the patch it had formed by the following season, without, in the interval, having received any attention whatever.

Most striking of all the mossy varieties is $S$. Wallacei, sometimes spoken of as $S$. Camposi, which has decorative foliage, considerably larger than most other varieties, while the lovely pure white flowers-quite giants by comparison, are strongly hawthorn scented. Here and there between the patches of the white mossy saxifrages, I grow the pink forms, like Rhei, Rhei superba, and Clibrana-they make very pleasing variations in the general colour scheme.

In the few places where I can permit a large plant to remain, Iberis sempervirens makes a brilliant hummock 
of white at this season, retaining its beauty for a considerable time.

In odd places I have a few plants of Anemone apennina, which in April give a pretty effect, with their pale blue flowers, while in one quiet corner I have planted in loam, leaf mould and sand, a small plantation of that lovely form of our wood anemone known as A. Robinsoniana. This is indeed a lovely plant, with large lilac blue flowers, containing a cluster of yellow stamens.

May seems to issue a "call to arms" to all the inhabitants of the Rock Garden to put their best efforts forward to make the very utmost of their beauties during this and the succeeding month. And how readily this summons is answered! Plants of all species seen to tumble over one another in their efforts to see which shall be in flower first, and which shall most readily attract the eye!

It is difficult to single out individual plants, and still more difficult to even attempt to describe all of them. If I mention a few, it is because they happen to come to my mind at the moment, and it does not follow that those left unnoticed are in any way inferior to them. Perhaps the Aubrietias claim attention first, hanging in soft cushions of lavender, pink and purple over the steep places, or mantling less precipitous ground in undulating hummocks of flower. 
In half-shady places Dodecatheons such as Hendersoni and splendens, thrust up their flower stems, terminating in a shower of cyclamen-like flowers, of rosy purple, or deepest crimson, with golden stamens well exposed.

These Dodecatheons, allied to the Primulas, and hailing, I believe, from moist woods of North America, appreciate peaty leafy soil, with sand and loam added, while a position not too much exposed to the sun is desirable.

In somewhat similar positions, the Erythroniums, or Dog's Tooth Violets, flourish. The mottled foliage of green and brown of our common Erythroniums is extremely pretty, especially when crowned with its delicate pink flowers, with chocolate stamens. Much more decorative and valuable for the Rock Garden, however, are some of the American forms of this charming genus, among the few only which I possess, Eryth. giganteum is very lovely, sending up slender stems to a height of twelve inches, and supporting beautiful lily-like flowers of a pale yellow colour, with brownish marking on the inside.

Trilliums also join these two foregoing plants in similar positions and the variety grandiflorum is a singular and beautiful plant, when its solitary white three-petalled flower is open.

In the bog bed, we have Primula sikkimensis, the Himalayan Cowslip fully out. This is perhaps one of 
the most charming of the primulas,-though not too happy in the South of England, I believe. From a slender stalk, some eighteen inches high, rising from a tuft of softly tinted green leaves, depend in a most graceful way lemon-yellow bell-shaped flowers, in the utmost profusion.

Near to this are clumps of that decorative $P$. Sieboldi, with its handsome foliage-the deep rose coloured varieties making a delightful foil to the yellow flowers of $P$. sikkimensis. Both of these plants with me like sunshine and ample root moisture, and are planted within a few inches of the pool.

In the small bog patches close at hand that larger relative of $P$. farinosa, viz., $P$. frondosa, is in full bloom, its rosy flowers much resembling those of its near relative, though the leaves are so heavily covered with farina on their backs as to be as white as a piece of paper, while that sweet little plant allied to the Gentians, Erythrea diffusa, is spangling the moist soil with its starry pink flowers.

The cascade of white tumbling over some rocks towards the centre of the garden is Arenaria montana, a " jewel of the first water," where we can spare the room to develop its full beauties as a prostrate plant, while here and there peeping at us on some ledge are the blue drum-stick-like flowers of Globularia nudicaulis.

From intermediate positions, as regards moisture, 
and where the soil is in no way specially good, rise the myriad tapering lavender spikes of Veronica gentianoides and its variegated form, while under the lee of some sheltering rock, in complete shade, and rising from the bronzy green leaves, often ranging to rich crimson, the lovely crimped edged flowers of Shortia galacifolia gleam in their satin-like surface and faint pink flush. I find almost pure peat, with a little sand and perpetual moisture, in addition to the shade already alluded to, necessary for this lovely plant.

On the moraine, Campanula excisa is scrambling about among the chips, while if we are fortunate, Eritrichium nanum rejoices us with its brilliant though diminutive flowers, and as we look at it, our thoughts wander to the hundred to one chances against this sweet little visitor being with us this time next year !

June in the Rock Garden! The words seem to suggest to the Alpine gardener a veritable rainbow of floral pigments. One's whole nature expands with happiness as we drink in the sweet perfumes, and appreciate the galaxy of colour with which the garden is flooded. Colours so soft and dainty, like those of Androsace sarmentosa, held aloft from their shaggy rosettes of leaves, Asperula suberosa with its wee pink trumpets, through the ever swelling note given by Aquilegia carulea and $A$. chrysantha to Dianthus deltoides and the golden radiance of Hypericum fragile, 


\section{I04 THE STORY OF MY ROCK GARDEN}

and past the rich chocolate and yellow of Cypripedium Calceolus and the stronger patches where the Helianthemums lie scorching in the sunshine.

Then the patches of yellow Sedums take up the tale in burning gold, and contrast their brilliancy with the ringing purple of Campanula pulla and pulloides, only to be hushed into quietness by the fiery note of Anemone fulgens, with its sheaf of coal-black stamens. In a cool bog bay, backed by the great leaves of Senecio clivorum, are the glorious orange globes of Trollius asiaticus, rising above its handsome foliage, while at its base are the rich crimson whorls of Primula pulverulenta, with its mealy stems, and a little further away $P$. japonica.

While in some moist and sunny position, well protected against drought, one catches a glimpse ofis it a fragment of the summer sky reflected in some tiny pool ? or a carpet of green strewn with sapphires? -upon closer inspection it rivals even these! it is Gentiana verna - the purest blue flower to be found in the whole world, and yet deigning to give its glorious beauty to even a London garden, and justly taking the position of the presiding deity over the many claimants for that honour during June-that month of loveliness in the Alpine garden. No idea of the brilliancy of this charming little plant can be conveyed by a description in words, or even by the artist's 
brush; the beauty of the flowers, them, can only be realized to the full by those who have seen them either in our gardens, or in the Alps. With me Gentiana verna does well, in sandy loam and leaf mould, kept moist during the Summer. The clumps increase and bear at times as many as a hundred flowers.

Unfortunately its near relative, $G$. acaulis, is not so tractable, and though it grows quite freely with me, only produces "blind" and empty calices, just when it should be studded with its huge blue trumpets.

June also sees that choice little silvery plant Geranium argenteum put forth its pink flowers, while that brilliant though diminutive Alpine pink, Dianthus alpinus, comes into bloom, growing only one inch high, in moist gritty soil, or the moraine, and with me, in full sun. The chief trouble I have with it is that during the Winter a tiny yellowish grub eats its way up the centre of the growths, causing each pair of leaves to fall off, and eventually killing the plant. I believe the eggs are laid by some fly, in the tissues of the plant, during the Autumn, and hatch out in the early Winter. I have tried frequent spraying with a solution of quassia chips from August onwards, but with very little result.

This month is the time of the Spanish Iris, and very charming they look planted in small groups, springing well above the more dwarf plants, while 


\section{Io6 THE STORY OF MY ROCK GARDEN}

protruding from fissures, through which the tap root can descend into cool soil, the great thrift, Armeria plantaginea, throws up myriads of rosy flowers on erect stalks, some fifteen to eighteen inches high.

Often this plant is still in flower in October and November, while only last year I counted fifty stalks on a single plant, each bearing a globular truss of blossom.

Spreading in a careless manner over the rocks and on to the path, the countless spikelets of Veronica rupestris-not far behind the Gentians in point of colour-join in the display.

The buttress-like stones rising from the path are in some cases clothed with the old double white pink, and very showy these clumps of grey foliage are surmounted by a sheaf of white.

From the rocky portions of the garden, the silvery rosettes of Saxifraga Hostii, S. Aizoon, S. cochlearis and $S$. lingulata lantoscana, are displaying their trusses of flower, while from points of vantage spring the huge two feet six inches plumes from Sax. Cotyledon v. pyramidalis.

In the Saxifrage corner S. Aizoon v. lutea and v. rosea vie with one another for attention, while spreading over the rocks bounding this portion of the garden are the silvery cushions of Dianthus casius thickly studded with their pink flowers. 
On the minute growth of Arenaria balearica creeping about like a moss, still linger numbers of its wee white flowers, while on the moraine the green rosettes of Camp. Allionii are now surmounted with its large, blue, trumpet-like flowers, making a very effective display.

From between the rocks, which will protect it to some extent from the excessive wet, the graceful pendant bells of Onosma echioides hang in quantities and well deserve their name of golden drops. Trailing masses of pink and lavender denote the Alpine phloxes, while the glaucous green hummocks of many divided leaves, spangled with whitish convolvulus-like flowers, call our attention to that lovely Oxalis enneaphylla from the Falkland Islands.

Of the dwarf Sedums I favour S. spathulifolium, both for neatness of growth and brilliancy of its rich yellow flowers, and if this is planted where its gold can contrast with that glorious trailing shrub Lithospermum prostratum the effect is delightful. The vivid blue of the Lithospermum can be seen during many months of the year, but it is perhaps at its best during June as it trails over some hot stones. I have mine planted in peaty loam with pieces of limestone and mortar in the soil, and while one grower advises sun and lime, and another says shade and peat, mine seems very happy in this intermediate compost! 
In the steep, moist, shady places the lovely Haberleas and Ramondias are flowering, the latter looking very charming as the spikes of purplish violet flowers, with a rich orange eye, rise from the rosettes of shaggy wrinkled leaves. Perhaps the illustration on page 77 may suggest in a modest way the richness of verdure and profusion of flower in a corner of my Rock Garden, and may serve to indicate the manner in which the rock springs from a flower-strewn path edge.

July is, to a very large extent, a repetition of June, especially when the temperature is moderate, and does not scorch up the flowers almost before they open, as in IgIr. However, we have valuable additions to make good the inevitable depletion due to those plants which have finished their period of flowering, and are fast ripening their seed. Such additions include Acantholimon glumaceum, or Prickly Thrift, with its numerous spikelets of bright rose-coloured flowers, projecting from its cushion of rigid sharply-pointed leaves, where it hugs some sun-baked rock.

Dianthus neglectus, that sweet little Pink, with its small narrow grass-like foliage quite inconspicuous when not in flower, is now spangled with its rich carmine blossoms, closing each evening, and exhibiting the softly tinted back of each petal. This is indeed a charming little plant, and best of all a good perennial, seemingly free from the quality, associated with so 
many Alpine Pinks, of "going off" without any apparent reason.

This plant seems to delight in gritty loam to which old mortar has been added, and the position, though fully exposed to the sun, should be one where the roots can find a moist medium through which they can run. As with $D$. alpinus, it is much better to err on the side of poor soil, since otherwise, more leaves than flowers may be the result.

Down some steep face of rock, exposed to full sun, that lovely Androsace, lanuginosa, is now in full flower, throwing up its primula-like trusses of pink blossoms, from its avalanche of silvery growths. It revels in such a position, especially if the soil is very gritty, as the stone over which it trails keeps its foliage clean and dry.

In the bog garden Iris Kampferi is opening its huge clematis-like flowers, though with me not too freely. The self-coloured varieties appear to me to be particularly lovely. Near to the Iris is Astilbe japonica v. Peach-blossom, with its waving masses of minute pink flowers, and as a carpet for it, surfacing the most peaty soil, the glorious blossoms of Mimulus cupreus v. Brilliant.

In that part of the garden devoted to the choicer Saxifrages; where the soil is very free, and also in the moraine, Erodium corsicum is now in full blossom. 


\section{IIO THE STORY OF MY ROCK GARDEN}

and very pretty the bright pink flowers look, surmounting its soft and downy leaves. Pratia angulata is also just now at its best, sheeting its close carpet of tiny leaves, with pale white lobelia-like flowers, which develop into a bright display of rosy purple berries in the early autumn.

On a protruding shoulder hangs a cloud-like mass of pink, denoting the presence of that pretty little plant Tunica Saxifraga.

In a sunny spot, with most rich soil, are the glowing carmine flowers of Pentstemon Hartwegii, while rippling over some rocks are the trailing growths of Tiarella cordifolia. The autumn tints on the foliage of this little plant are also a great attraction.

Floating on the surface of the little pool are the bronzy-green leaves of my Nymphaa marliacea, with their charming pink goblet-like flowers, while near by are the white cymes of the Aponogeton distachyon, advantageously displayed among its long green floating leaves.

As July merges into August, we have the flowers of the lovely Japanese balloon-flower Platycodon v. Mariesii, of the richest blue, while Sedum altissimum and Sedum Kamtschaticum are in full flower, the latter being particularly effective with its rich yellow blossoms. The Linarias, too, are scrambling about in all directions, in varied shades of yellow and brown, 
while in close cushions over sun-baked rocks grows that lovely Scabiosa, Pterocephala, with its large heads of pink flowers, shortly to be followed by such decorative fluffy fruit.

On the bog we now have the rich violet coloured flower of Pinguicula vulgaris, especially interesting owing to the sticky, insect-feeding propensities of its light green leaves.

By the water-side too, that late Primula, Poissoni, is in flower. In crevices between the rocks, backed by very poor gritty soil, from a flat spreading foundation of silvery foliage, Potentilla nitida is throwing up its pink flowers, while scrambling about in every odd corner are the dainty pendulous bells of Campanula pusilla, both white and blue, and close tufts of Camp. garganica, as shown on page 57 .

On dry, sun-baked positions, the brilliant yellow flowers of Cistus formosus, and the reddish purple ones of $C$. purpureus, each with the characteristic purple blotch at the base of their petals-are seen, while on sloping ground, in a moderately sunny place in moist peaty soil, spreads the prostrate growth of Dryas octopetala, spangled with its shaggy fruit.

September with its cool nights and shorter days, sees a considerable diminution of flower in the garden, still, such things as Antirrhinum Asarina, trailing in some hot position, are covered with creamy flowers- 


\section{II2 THE STORY OF MY ROCK GARDEN}

Campanula muralis is still gay with its deep violet bells, while the Eryngiums are just coming into their full beauty; the inflorescence of $E$. alpinum, of a metallic blue shade, is most imposing, while $E$. giganteum shimmers in its grey tone; both last for weeks and are most decorative.

On the bog, Lobelia fulgens is very showy, with its dazzling carmine flowers and crimson foliage, while its blue companion syphilitica makes a charming contrast.

Cyclamen europeum also is at its best now, the roundish dark green leaves carpeting the ground in shady places, and rising from between them the numerous flowers of reddish purple.

Enothera missouriensis, of prostrate habit, with silvery green leaves, and clear yellow flowers, will be gay with blossom until the end of October; the white Enothera taraxacifolia, too, has each evening a profusion of lovely white sweet-smelling flowers upon it, which by early morning will be rich pink.

Sax. Fortunei, from China, is in flower this month, throwing up from its glossy leaves stalks some twelve to sixteen inches high, and daintily arranged on these are the quaint white flowers, with three short petals and two long ones, as in Sax. sarmentosa; the position I find most suitable is a semi-shady one, where the soil is moist. The danger with this plant is the liability of its blossoms being spoilt by early frosts. 


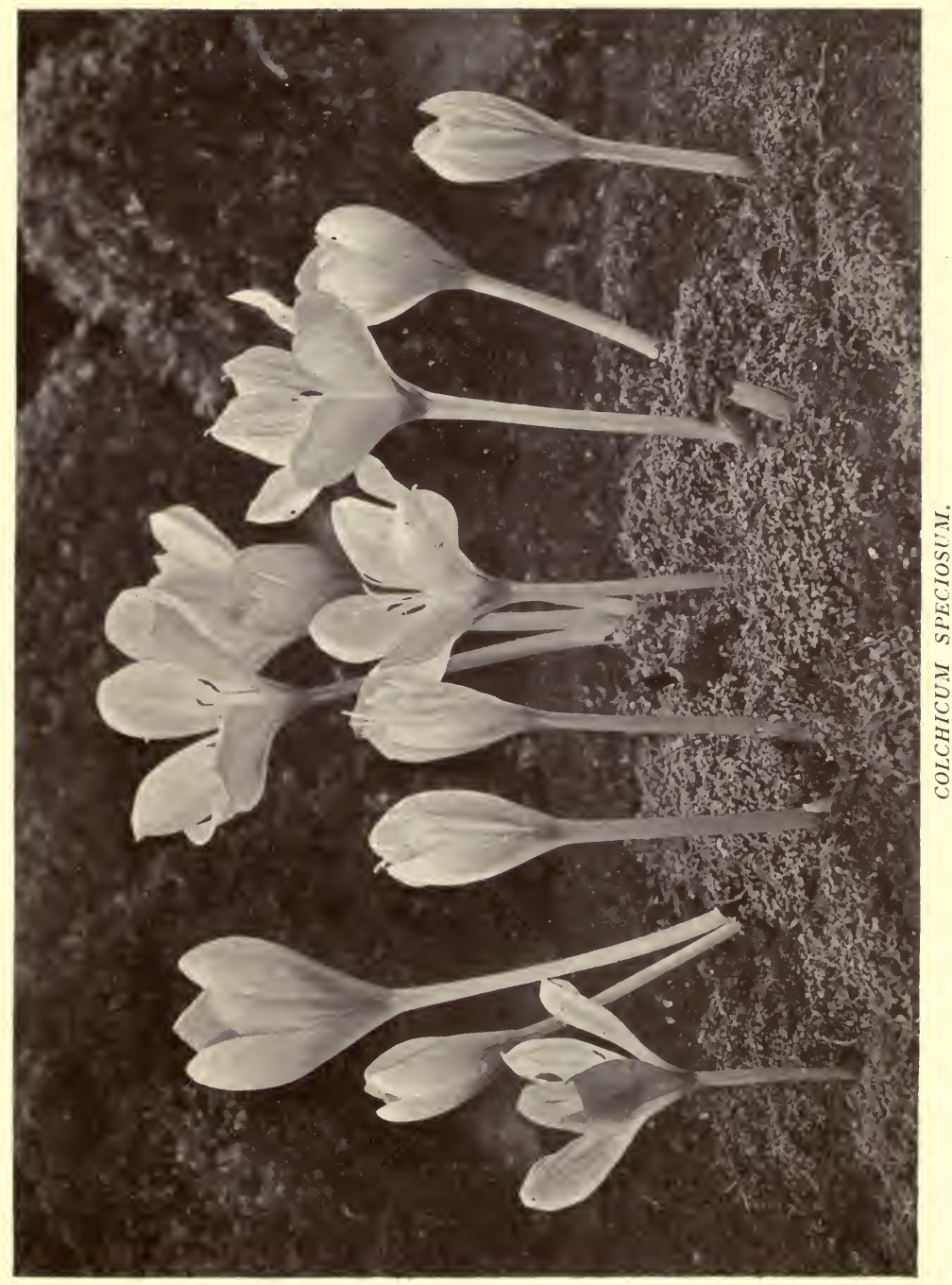




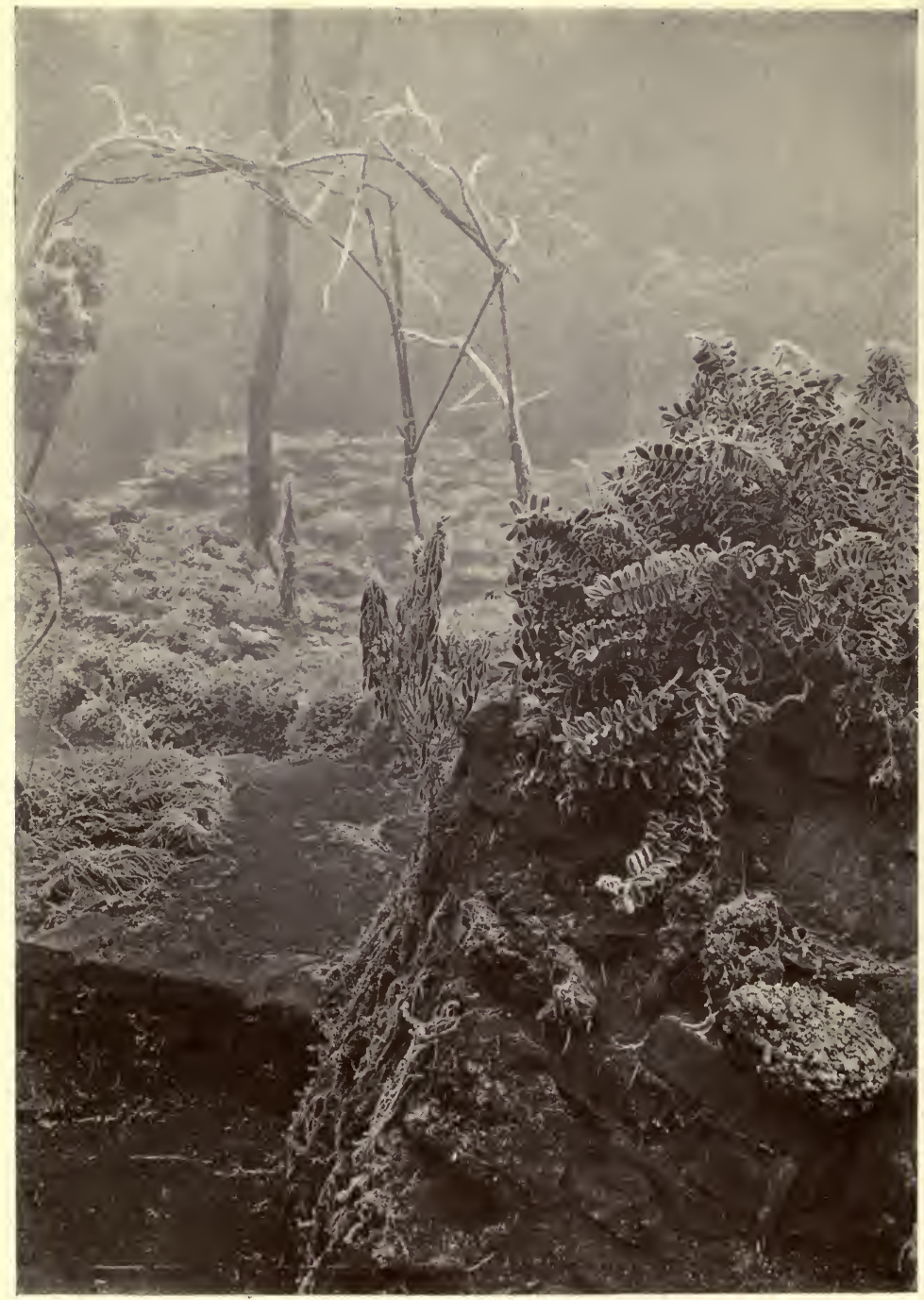

HOAR FROST AND MIST IN MY GARDEN. 
On rocky knolls, shimmering in the sunshine, lie the prostrate growths, terminated with heads of pink flower, of Sedum Sieboldii and S. turkestanicum, both excellent Autumn flowering stonecrops, the foliage alone of the former being glorious in its many ruddy tints. Snails appear to have an especial partiality for this variety, and it needs some attention to prevent them devouring the whole of it.

At the end of the month, and merging into October, come the glorious rosy purple goblets of Colchicum speciosum, also C. byzantinum, C. autumnale, and others, giving a welcome touch of colour to the departing year, while before they are completely over, that showy Crocus, C. speciosus comes along, to continue the story, its rich bluish-violet flowers striped with purple, and protruding from this lovely cup is the remarkably branched orange-coloured stigma. C. zonatus, though of a more delicate colouring, pleases us at this time.

Even now quite a lot of flower remains on Campanula pusilla, while that Californian Fuchsia, Zauschneria californica, growing in some dry sunny place in the Rock Garden, is brilliant with its vermilion flowers.

To me the choicest visitor during October is the beautiful Cyclamen neapolitanum and its pure white variety. The flowers rise from the bare soil in some shady spot, and are followed by decorative green leaves 


\section{II4 THE STORY OF MY ROCK GARDEN}

marbled with white. The seed stems, as I mentioned earlier, coil themselves into a spiral, and so draw down the fruit to the earth. The white variety is illustrated by the photograph on page 97 .

November usually gives us but little that is really fresh, and the garden is mostly decorated 'by the remnants of the earlier months, or plants which are flowering a second time, and so out of their regular season. Nevertheless, there is usually quite a number of things to be seen-while the most showy of all are the lovely cobalt blue flowers of Plumbago Larpenta, thickly mantling the tuft of bronzy crimson leaves. This plant is a native of China, and despite my cold, heavy soil, thrives apace, and is indeed a "beauty" so late in the year! At this time, too, Primula capitata often sends up its flowers, and if protected by a roof glass, will remain in good condition until mid-December, or even later.

With the exception of the Christmas Rose, whose charming softly-tinted blossoms are now at their best, rising from among the much divided dark green foliage, and whose appearance we have anticipated with the greatest pleasure, December in my garden produces little or nothing I have not already mentioned in the way of flowers. Usually there are a number of late comers still lasting, and occasionally a few early things, even earlier than is their wont. 
The chief charm of December is, however, the transformation, often during a single night, caused by the fairy fingers of the hoar frost.

The most humble fragments of withered foliage and seed stems become edged with ropes of glittering facets, while the lime spots of the encrusted saxifrages seem to have a special attraction for the hoar frost, where the crystals arrange themselves upon the leaves like fringes of silver. Old seed stems of many of the Sedums assume a beauty rivalling the hey-day of their flowering season, and take on the aspect of pieces of coral. The illustration on page 16 gives some idea of these frost " flowers," while when the kindly curtain of mist comes down to soften the outlines of surrounding houses, left painfully bare by the falling leaves of Autumn, the decorative touch of the hoar frost is still more appreciated.

The reproduction on page Ir 3 gives some idea of a December day in my garden-when the glittering jewels of the frost, which have been deposited with such a lavish hand on everything, are reflecting the light in a myriad dancing points; and to my mind, make a fitting close to a year which has been one continuous stream of loveliness and joy. 


\section{CHAPTER VIII}

\section{RETROSPECT}

HAviNG told in a brief way the "Story of My Rock Garden "from the time of its inception to the present day, it only remains for me to summarise the chief advantages which such a garden has, and to emphasize how intensely interesting a tiny piece of ground can be, if we will only make close personal friends of its little inhabitants.

As I have previously pointed out, every day through the year finds something fresh coming through the soil to greet us, or lingering to a late time of the season, so as to accompany us to a fresh beginning. Such a garden teaches us to appreciate more keenly the small things of Nature, and especially those which have come directly from Nature's workshop, than is possible with such plants as have been, to a large extent, evolved by the hands of the skilled florist.

To me many of these minute plants, with their pure, unassuming, simple flowers, are much more attractive than the large and showy blossoms, so frequently admired, and alas! too often of such brief decorative 
value. Without in any way wishing to disparage the wonderful results which have crowned the efforts of the skilled horticulturist, I do think that there is more pure enjoyment to be obtained from the close association with these charming mountain plantswith their intensely interesting methods of adaptation to their special conditions, than in devoting one's small garden to the production of plants, often in themselves far from elegant, which produce wonderful, though I think in many cases less really beautiful flowers-for a short period during the Summer.

Then again this form of gardening lends itself essentially to decorative or artistic treatment (and surely to the best form of that art), since to be successful one must not only make one's garden into a picture, but it must so closely follow the great ideal of Nature as to provide suitable homes for its little inhabitants.

With the average garden plant, one's value of it is, to a large extent, limited to how much flower it will produce-whereas, with the majority of our mountain friends, we are anxious for them to be always in perfect condition, thereby decorating their special niche in our garden, and when in their seasons they spread their blossoms to our gaze, we accept them as additional evidence of their kindly feeling towards us, and an expression of their appreciation of what we have done for them. 


\section{II8 THE STORY OF MY ROCK GARDEN}

These remarks apply specially to those of us who are placed as myself, with but a small piece of garden with which we are in close contact, and consequently, a place we are anxious should be always decorative and refreshing to our gaze, when we are able to give what little spare time we may have to exploring it.

On the question of expense too, it has this advantage, that, though it is possible, indeed easy, to usefully employ a large sum, it is quite as easy to get a large amount of enjoyment for a small outlay, if we are content to proceed slowly, and form our garden bit by bit, as opportunity. and finances allow.

I know of no other kind of gardening which so lends itself to a gradual extension as this; indeed, with several friends who originally started with a rockery in one part of their garden, it is becoming a matter of course to add to it each Autumn, since the pleasure derived from its neat and brilliant occupiers outweighs that provided by the ordinary border.

To a considerable degree one can see at a glance the contents of an orthodox garden, especially if it is laid out in regular series of plants in different colours ; compare this with the varied outline of a well-planned rock garden, where every nook and corner has its own special inhabitant !-(so much so, that we may wander in it for hours and be still finding something hitherto overlooked)-and we at once realize how 
much more refreshing the latter is, especially to those who are nature lovers as well as gardeners.

When once established, too, the Alpine garden requires less time given to it, since the annual digging of the herbaceous border is dispensed with, and most of the plants are perennial, while such keeping in order as is required can well be done at odd moments.

In taking leave of my readers I would express the hope that this short account of what $I$ have done in my own little garden, may lead others to embrace this form of horticulture, which from my own experience, provides such an ever-increasing fund of healthy and pleasurable recreation. 


\section{APPENDIX.}

As an aid to those about to start a rock garden, under anything like the conditions prevailing here, I append some lists of plants which I find appreciate various positions. While I' do not suggest for a moment that such plants will not grow, and even thrive, in other positions in different districts, I do not think serious errors will occur if the novice adheres to such until he is familiar with the plants, when he will be able to decide just what positions they require under his particular environment.

- I have been careful to include only such subjects as I have had experience of for some time, thereby obtaining a more just idea of their requirements than would have been the case had I included everything I now grow.

\section{A.-PLANTS WHICH THRIVE IN HOT SUNNY POSITION IN SANDY OR GRITTY SOIL.}

Achillea.

Huteri.

Æthionema iberideum. Alyssum montanum.

" saxatile.

" spinosum.

Anemone hortensis. Antirrhinum Asarina.

, glutinosum.
Cistus formosus.

$$
\text { " purpureus. }
$$

Corydalis lutea.

Cotyledon chrysanthus.

Erodium chamaedryoides.

" chrysanthum.

" macradenum.

" sibthorpianum.

" supracanum. 
Geranium argenteum.

Helianthemums, in varieties.

Iris tectorum.

Portulaca grandiflora.

Sedum acre aureum.

" altissimum.

" anglicum.

, asiaticum.

" cœruleum.

" dasyphyllum.

" glaucum.

" obtusatum.

" sexangulare.

Sempervivum Allionii.

" arachnoideum.

" arvernense.

" atropurpureum.

" blandum.

" boutignyanum.
Sempervivum calcareum.

chrysanthum.

ciliatum.

doellianum.

Fauconneti.

fimbriatum.

Funkii.

globiferum.

Heuffelii.

Laggeri.

Moggridgei.

patens.

Pomelii.

ponticum.

Reginæ-Amaliæ.

tectorum.

triste.

Verloti.

Zauschneria californica.

B.-PLANTS WHICH THRIVE IN SUN WITH A MODERATELY MOIST ROOT RUN.

Acæna Buchanani.

" inermis.

" microphylla.

Acantholimon glumaceum.

Anemone apennina v. alba.

Pulsatilla.

Antennaria dioica, rosea.

tomentosa.

Aquilegia cærulea.

"

canadensis.
Aquilegia chrysantha.

Skinneri.

Arabis procurrens.

variegata.

Arenaria montana.

purpurascens.

Armeria cæspitosa.

Arnica montana.

Artemisia borealis.

" lanata. 
Artemisia vallesiaca.

Aster alpinus.

Aubrietias in varieties.

Berberis dulcis pygmœa.

Bulbocodium vernum.

Campanula barbata.

" garganica.

", var. hirsuta:

glomerata.

,

, Hendersoni.

, Mayii.

" portenschlagiana.

, pulla

, pulloides

, rotundifolia.

Carlina acanthifolia.

Cerastium Biebersteinii.

tomentosum.

Chionodoxa Luciliæ.

var. sardensis.

Colchicum autumnale.

byzantinum.

,

speciosum.

Coronilla cappadocica.

Corydalis bulbosa.

Cotoneaster adpressa.

Crocus biflorus.

humifusa.

" chrysanthus.

" Imperati.

"Sieberi.

, speciosus.
Crocus versicolor. vitellinus. zonatus.

Cryptomeria spiralis. Cupressus chinensis.

aurea.

Daphne Mezereum.

Delphinum nudicaule.

Dianthus cæsius.

carthusianorum.

deltoides.

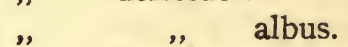

fimbriatus albus.

Freynii.

graniticus.

plumarius.

" superbus.

Dryas Drummondii. octopetala.

Eranthis hyemalis.

Erica carnea.

alba.

Erinus alpinus.

Eryngium alpinum.

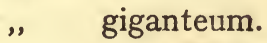

" oliverianum.

" planum.

Erysimum pumilum. rupestre. Fritillaria meleagris. Galanthus cilicicus. Ikariae.

Gentiana acaulis. 
Gentiana septemfida. verna. verna, var. alba.

Genista pilosa.

" sagittalis.

„. tinctoria.

Geranium striatum.

Geum montanum.

Gnaphalium Leontopodium.

Gypsophila cerastioides.

Hieracium villosum.

Hippocrepis comosa.

Hyacinthus azureus.

Hypericum fragilis.

humifusum.

olympicum.

reptans.

Iberis correafolia.

" sempervirens.

Iris florentina.

," germanica.

„ pumila.

" reticulata.

Leucojum æestivum.

Linaria alpina.

Linum flavum.

$$
\text { salsoloides. }
$$

Lithospermum intermedium.

Lychnis haageana. prostratum.

" Lagascæ.

Mentha Requienii.

Mertensia echoidies.

Muscari botryoides.

var. album.

Narcissus Barrii.

Bulbocodium.

"

,

9

9

9

,

9

3

9

ss "var. citrinus.

, var.

conspicuus.

, var. monophyllus.

cyclamineus.

Johnstoni.

juncifolius.

minor, var.

minimus.

Pseudo-narcissus. triandrus.

Enothera cæspitosa.

Onosma albo-roseum.

echioides.

Papaver nudicaule.

Pentstemon Hartwegii.

Phlox amœna.

subulata in varieties.

Phyteuma Scheuchzeri.

Picea pygmœa.

Pinus sylvestris nana.

Platycodon grandiflorum.

Plumbago Larpentæ.

Potentilla alpestris.

Pratia angulata.

Primula calycina. 
Primula integrifolia.

" marginata.

" Palinuri.

, villosa.

"viscosa.

Puschkinia scilloides.

Romulea Bulbocodium.

Rosa nana.

Saponaria cæspitosa.

Saxifraga Aizoon.

" $\quad$ Cotyledon.

"

var.

pyramidalis.

sancta.

Scabiosa Pterocephala.

Scilla bifolia.

" " var. alba.

" " var. rubra.

"peruviana.

" sibirica.

" "var. alba.

Sedum Ewersii.

" Maximowiczii.

"reflexum.

" $"$ monstrosum.

" Sieboldii.
Sedum spathulifolium.

Senecio Grayi.

Silene alpestris.

Sternbergia lutea.

Thymus azoricus.

" Serpyllum.

" " var.

"strictus.

Tropæolum polyphyllum.

Tulipa clusiana.

„ kaufmanniana.

" primulina.

" pulchella.

Tunica Saxifraga.

Veronica Bidwilli.

" canescens.

" cupressoides.

" incana.

" pectinata.

Viola bosniaca.

" calcarata.

" cornuta.

" gracilis.

" hederacea.

lanuginosus. 
Cyclamen repandum.

Cypripedium Calceolus.

Dianthus sylvestris.

Dodecatheon Hendersoni.

Galax aphylla. Meadia.

Helleborus niger.

Orchis mascula.

Oxalis enneaphylla.

Phlox divaricata.

Pratia arenaria.

Saxifraga cæspitosa.

Saxifraga hypnoides.

9

" juniperifolia.

„ Lindleyana.

„ muscoides.

3

19

, palmata.

, taygetea.

, Wallacei.

Shortia galacifolia.

Trillium grandiflorum.

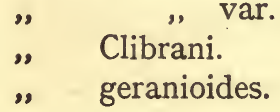

var.

Whitlavii.

var. Rhei. var. Rhei superba.

D.-PLANTS WHICH PREFER FULL SHADE.

Cystopteris bulbifera.

Polygonum vaccinifolium.

fragilis Dickieana. Ramondia pyrenaica.

Haberlea rhodopensis.

Omphalodes verna.

serbica.

Saxifraga Andrewsii.

\section{E.-PLANTS WHICH THRIVE IN "SEMI-BOGGY"} POSITION, WHERE VEGETABLE SOIL IS ALWAYS MOIST.

Androsace carnea.

Anemone Robinsoniana.

Aquilegia alpina.

Arisarum proboscideum.

Arrhenatherum bulbosum

variegatum.
Briza maxima.

Caltha palustris.

" polypetala.

Cardamine pratensis.

Cotula squalida.

, acænœfolia. 
Erythraea diffusa.

Erythronium.

Frankenia lævis.

Fritillaria aurea.

Hacquetia Epipactis.

Homogyne alpina.

Linnæa borealis.

Mazus Pumilio.

Parnassia palustris.

Pinguic'lla vulgaris.

" capitata.
Primula cortusoides.

" denticulata.

" farinosa.

" frondosa.

" involucrata.

" minima.

Ranunculus amplexicaulis.

Salix herbacea.

Saxifraga aspera.

Soldanella alpina.

Viola hederacea.

F.-PLANTS WHICH THRIVE IN WET, BOGGY PLACES.

Astilbe japonica.

Geum rivale.

", rivale, Lenard's var.

Iris laevigata.

, Pseudacorus.

Lobelia fulgens.

" syphilitica.

Menyanthes trifoliata.

Mimulus luteus.

Myosotis palustris.
Primula japonica.

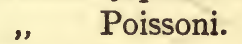

,r rosea.

, sikkimensis.

Sarracenia purpurea.

Saxifraga peltata.

Senecio clivorum.

Spiræa Aruncus.

Trollius asiaticus.

", europæus.

\section{G.-PLANTS WHICH I GROW SUCCESSFULLY IN MY MORAINE.}

Anemone vernalis.

Campanula Allionii.

" cenisia.
Campanula excisa.

$$
\text { Zoysii. }
$$

Douglasia vitaliana. 
Draba aizoides.

" dedeana.

" pyrenaica.

Geum reptans.

Myosotis alpestris.

Papaver alpinum.

Ranunculus alpestris.

glacialis.

Saxifraga aizoides, var.

atrorubens.
Saxifraga oppositifolia, var.

alba.

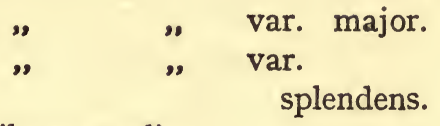

Silene acaulis.

„, acaulis var.

pedunculata.

Wahlenbergia serpyllifolia.

" dinarica.

H.-PLANTS WHICH ACCOMMODATE THEMSELVES PRACTICALLY ANYWHERE.

Anemone japonica.

alba. rubra.

Arabis albida.

Arenaria balearica. verna.

Armeria maritima.

Bellis perennis.

Campanula carpatica.

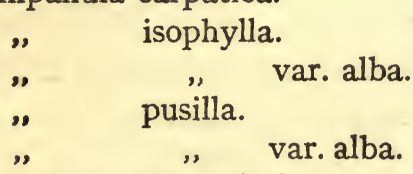

Epilobium nummularifolium. Lychnis Viscaria.

Epimedium pinnatum.

Linum perenne.
Erythronium Dens-canis.

Galanthus Elwesii. nivalis.

Geranium lucidum. Robertianum.

Helxine Solierolii.

Heuchera brizoides.

sanguinea.

Ionopsidium acaule.

Iris xiphiodies.

„ Xiphium.

Linaria Cymbalaria. hepaticæfolia. pallida. vulgaris. Montbretia in varieties. 
Nigella damascena.

Enothera fruiticosa, var.

Youngii.

" missouriensis.

, rosea.

Ornithogalum umbellatum. Phyteuma campanuloides. Primula Auricula.

$$
\text { " } \quad \text { elatior. }
$$

Saponaria ocymoides. Saxifraga cordifolia.

$\begin{array}{ll}\text { " } & \text { cuneifolia. } \\ \text { " } & \text { Geum. } \\ \text { Hostii. } \\ \text { " } & \text { rotundifolia. } \\ \text { sarmentosa. } & \text { trifurcata. } \\ \text { " } & \text { umbrosa. }\end{array}$

"

„ var. minor.

", „ var. serratifolia.

Scutellaria galericulata.

Sedum acre.
Sedum album.

Anacampseros.

" Kamtschaticum.

" , variegatum.

"roseum

" rupestre.

" spurium.

"Telephium.

Silene Schafta.

Spiræa Filipendula. Symphyandra pendula.

Tellima grandiflora.

Teucrium pyrenaicum.

Thalictrum aquilegifolium.

Thuya nana aurea.

Tiarella córdifolia.

Tolmiea Menziesii.

Veronica gentianoides.

"repens.

" spicata.

" Teucrium, var.

dubia.

\section{I.- PLANTS WHICH PREFER SEMI-MORAINE} POSITIONS, SOIL HALF-GRIT, AND IN FULL SUN.

Androsace lanuginosa.

" sarmentosa.

" sempervivoides.

" villosa.

Asperula suberosa.
Dianthus neglectus. petræus.

Draba bruniæfolia. Potentilla ambigua. nitida. 
Potentilla nitida, var. alba Saxifraga Griesebachii. villosa.

Saxifraga Aizoon, var. lingulata, var.
lantoscana. lingulata, var.
lantoscana.

longifolia.

rocheliana.

Salomonii.

Senecio incanus, var. Persooni.

$\rightarrow$

,

",

" $\quad$ Burseriana.

" catalaunica.

" cochlearis.

rosea.

lutea. " var. minor. Wahlenbergia serpyllifolia. crustata. 


\section{INDEX.}

ACANEA, 35.

Acantholimon glumaceum, 50, 66, 108.

Alpine Plants, evergreen character of, 15 ; definition of term, 20 conditions of growth in natural habitat, 21 ; protection of in winter, 24 ; carpeting, 35 ; long roots of, 50 ; with silvery foliage, 56 ; propagating, 63 et seq., by seed, 69.

Androsace sarmentosa, ro3.

". lanuginosa, rog.

Anemone apennina, 10o.

" blanda, 95 .

" fulgens, ro4.

"nemerosa Robinsoniana, $85,100$.

Pulsatilla, 97 .

Antirrhinum Asarina, I I I.

Aponogeton distachyon, I Io.

Aquilegia alpina, 86.

" cærulea, то3.

, chrysantha, ro3.

Arabis, 97.

$$
\text { chrysantha, ro3. }
$$

Arenaria balearica, $35,46,52$, ro7.

" cæspitosa, 35.

" montana, ro2.

Arm'́ria plantaginea, 50, Io6.

Artemisia vallesiaca, 56 .

Asperula suberosa, 3I, 103.

Astilbe japonica, ro9.

Aubrietias, 49.
Bogs, construction of, 27 ; plants for, 27, 32, 52, 84 . Bowles, E. A., 16. Bulbocodium vernum, 96. Bulbous plants, 59 .

Caltha palustris, 97. " polypetala, 97.

Campanula Allionii, 44, 107.

" cenisia, 44 .

" excisa, $44,103$.

" garganica, 1 II.

" muralis, II2.

" pulla, 104.

" pulloides, I04.

" pusilla, III, II3.

". Zoysii, 44.

Campanulas, $34,5^{8}$; propagating, 66.

Cement Concrete, as substitute for stone, 16 .

Cerastium tomentosum, 49.

Cistus formosus, III.

,. purpureus, III.

Colchicum autumnale, Ir3.

" byzantinum, II3.

, speciosum, 59, II3.

Cotula squalida, 35,85 .

Crevice planting, 76 et seq.

Crocus chrysanthus, 94 .

"I Imperati, 94.

") sieberi, 94.

") speciosus, Ir 3 .

". versicolor, 97.

" vitellinus, 91. 
Crocus zonatus, II 3.

Cyclamen Coum, 93.

Cyclamen europeum, II2. 1) ibericum, 93. neapolitanum, 59, II 3.

Cypripedium Calceolus, I04.

Daphne Mezereum, 92.

Dianthus Alpinus, ro5.

". cæsius, ro6.

" deltoides, Io3.

Dodecatheons, IOI. neglectus, 108.

Draba aizoides, 98 .

Drainage, 23.

Dryas octopetala, III.

EDRAIANTHUS serpyllifolius, 3 I. Eranthis hyemalis, 61, 92.

Eritrichium nanum, 34, 44, 103.

Erodium corsicum, rog.

Eryngium alpinum, II 2.

giganteum, II 2.

Erythræa diffusa, 102.

Erythroniums, 85, ror.

Galanthus Elwesii, 92.

Gentiana acaulis, 105.

verna, 104.

Gentians, from seed, 75 .

Geranium argenteum, 105.

Glass protectors, 24.

Globularia nudicaulis, ro2.

HABERLEAS, 30, 108.

Helianthemums, 55, 104

Hepaticas, 94.

Hypericum fragile, 103.

IBERIS sempervirens, 99 .

Ionopsidium acaule, 6r.

Iris Kæmpferi, Iog.

, reticulata, 94 .

JUNIPERUS chinensis, 88.

LeUCOJUM vernum, 94.
Linaria alpina, 46, 6r, 62 .

Linnæa borealis, 85 .

Lithospermum prostratum, 107.

Lobelia fulgens, 112.

", syphilitica, II2.

Mimulus cupreus, 109.

Moraine, the, 37 et seg. ; plants for, 43 .

Narcissus Bulbocodium, 60, 92.

" cyclamineus, 96 .

" minimus, 96.

, triandrus, 96.

Nymphæa marliacea, I 1 .

CENoThera missouriensis, II 2.

" taraxacifolia, II2.

Onosma echioides, 107.

Osmunda regalis, 54 .

Oxalis enneaphylla, 107.

Pentstemon Hartwegii, iro.

Petrocallis pyrenaica, 43.

Phloxes, propagating, 66.

Pinguicula vulgaris, I II.

Platycodon Mariesii, Iro.

Plumbago Larpentæ, 114.

Potentilla nitida, III.

Pratia angulata, 110.

Primula auricula, 54, 66, 8o, 98 .

" capitata, 92, 114 .

, denticulata, 52, 65, 97.

" farinosa, 85,98 .

". frondosa, 85, 102 .

"involucrata, 85.

" japonica, ro4.

". marginata, 98.

" Poissoni, r 10.

" pulverulenta, 104 .

" rosea, 66,85 .

" Sieboldi, 102.

" sikkimensis, 10r.

" viscosa, 54 .

RAMONDIAS, 30, 80, 107.

Robinson, William, 33. 
Rock Garden, pleasure of the, 18; planning and building, 25 et seq. : trees in, 35; planting, 49 et seq., 76 et seq. ; cement in the, 83 ; expense of $a, 118$.

SAXIFRAGA aizoon, ro6.

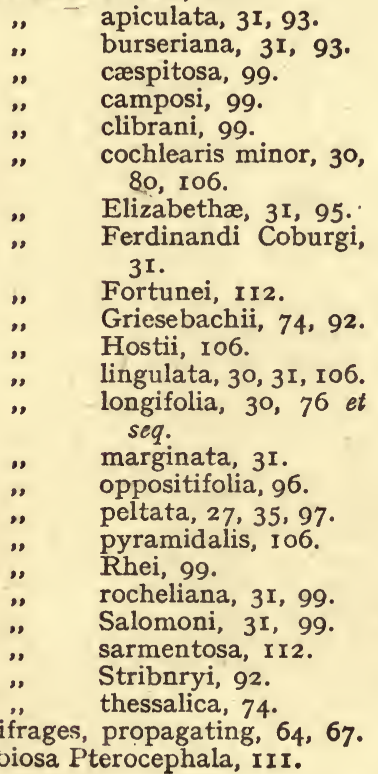

Scilla bifolia, 94 . sibirica, 94.

Sedum Sieboldii, Ir3. "s spathulifolium, I07.

Sedum turkestanicum, 86, II3.

Sedums, propagating, 65 .

Sempervivum arachnoideum, 56. triste, 7 .

Sempervivums, propagating, 55 . Senecio incanus, 57.

Shortia galacifolia, ro3.

Silene acaulis, 44 .

Soil, treatment of heavy, 17,26 ; value of grit in, 30, 3I, 46 .

Soldanella alpina, 86; 98.

Spanish Iris, 6r, I05.

Stepping stones, 29.

Stone, substitute for, I6; advantage of real article, I7 ; retains moisture, 23.

TIARELla cordifolia, rio.

Trees, large not desirable, 35 ; dwarf, 86.

Trollius, asiaticus, 104.

Tunica Saxifraga, I Io.

VERONICA gentianoides, IO3.

Violä gracilis, 97.

WATER, value of, 23,30 ; plants for, 52 .

ZAUSCHNERIA californica, I I3. 

THIS BOOK IS DUE ON THE LAST DATE STAMPED BELOW

RENEWED BOOKS ARE SUBJECT TO IMMEDIATE RECALL

26 JUN 63 IND

LIBRARY, UNIVERSITY OF CALIFORNIA, DAVIS

Book Slip-35m-7,'62 (D29684)458 


\section{9}

\section{Malby, R.A.}

The story of my

rock garden.
SB459

M26

1919

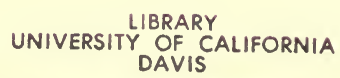


d

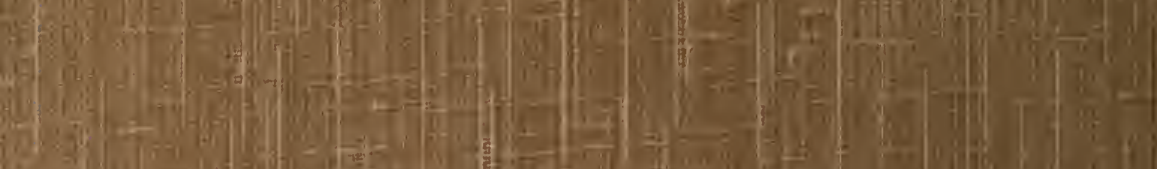
t) $=y^{-1}$ (2) 1. $4(-5)=0$

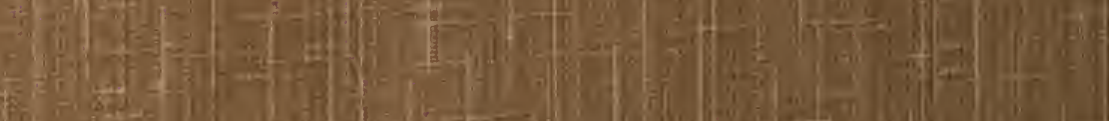
atect

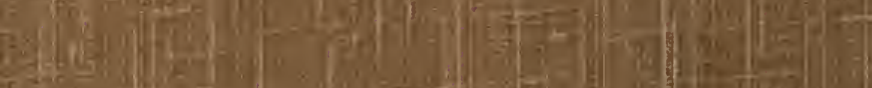

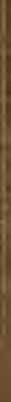

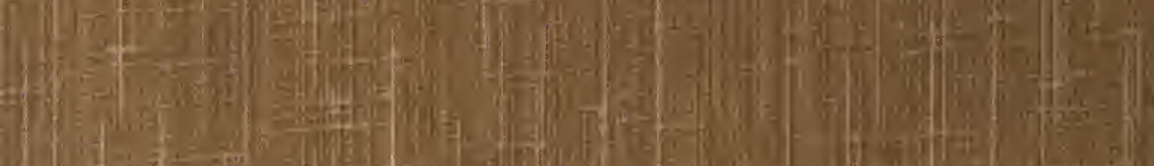

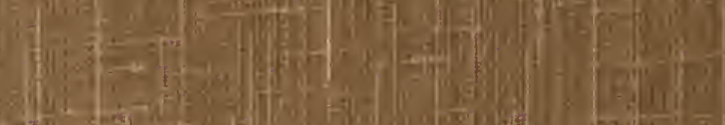

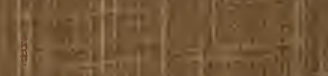

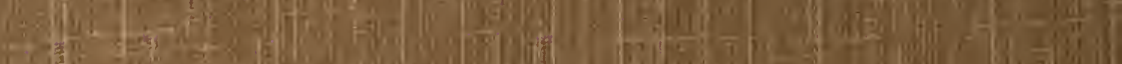

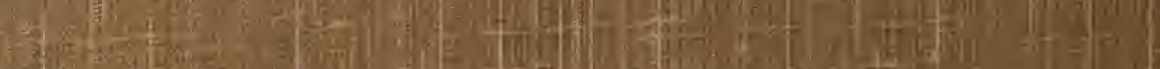

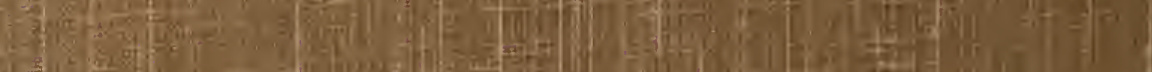

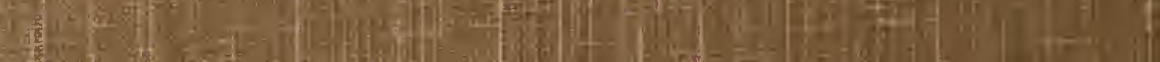

